Universidad de Lima

Escuela de Posgrado

Maestría en Tributación y Política Fiscal

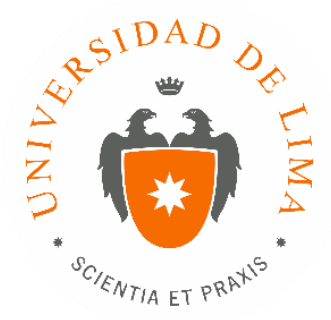

\title{
LA IMPLEMENTACIÓN DE UN EFECTIVO INTERCAMBIO DE INFORMACION FISCAL EN EL PERÚ
}

Trabajo de investigación para optar el Grado Académico de Maestro en Tributación y Política Fiscal

URTEAGA GOLDSTEIN, CLARA ROSSANA

Código 20021611

\author{
Asesor \\ Ramón Bueno-Tizón Vivar \\ Lima - Perú \\ Julio de 2017
}


(Hoja en blanco) 


\section{LA IMPLEMENTACIÓN DE UN EFECTIVO INTERCAMBIO DE INFORMACION FISCAL EN EL PERÚ}




\section{TABLA DE CONTENIDO}

INTRODUCCIÓN.................................................................................................. 1

\section{CAPITULO I: LOS ACUERDOS DE INTERCAMBIO DE}

INFORMACIÓN..............................................................................................5

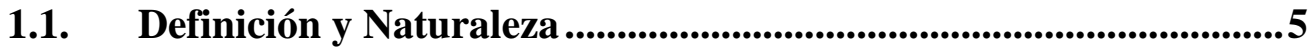

1.2. Objeto del intercambio .......................................................................7

1.3. Modalidades de Intercambio de Información .....................................9

1.3.1. Intercambio a Requerimiento ...................................................10

1.3.2. Intercambio Espontáneo...................................................................11

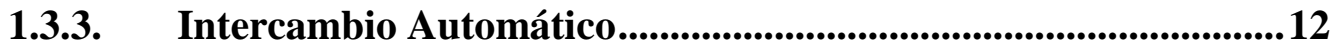

CAPÍTULO II: EL INTERCAMBIO DE INFORMACIÓN EN EL

PANORAMA INTERNACIONAL ..............................................................14

2.1. El Modelo OCDE .............................................................................15

2.1.1. Breve reseña del artículo 26 del MOCDE......................................15

2.1.2. El artículo 26 en el MOCDE 2014 .................................................. 17

2.2. El Modelo ONU ...............................................................................................19

2.3. Ley de Cumplimiento Tributario de Cuentas Extranjeras-FATCA 21

2.4. Convención Multilateral sobre Asistencia Administrativa Mutua en

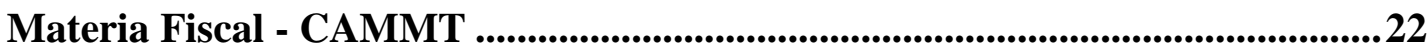

2.5. Intercambio Automático de Información - CRS: Un nuevo estándar 23

2.6. El Plan BEPS 26

2.6.1. La Acción 13 del Plan BEPS - Documentación sobre Precios de Transferencia e Informe País por País ......................................................................26 CAPÍTULO III: LÍMITES AL INTERCAMBIO DE INFORMACIÓN

3.1. Derechos del Contribuyente: Desarrollo y estado actual ................29

3.1.1. Principios del sistema tributario ....................................................332

3.1.2. Clasificación de los derechos del contribuyente ...........................34

3.1.3. Test para verificar la viabilidad de las prácticas del Estado ......36 


\section{CAPÍTULO IV: INTERCAMBIO DE INFORMACIÓN EN EL PERÚ}

.39

4.1. El Perú en el contexto global.................................................................39

4.2. Los Tratados suscritos por el Perú y el intercambio de información 41

4.3. La normativa interna................................................................................ 45

4.3.1. La АAMMT ............................................................................................46

4.3.2. Disponibilidad de la información......................................................49

4.3.3. El Secreto Bancario - Un nuevo enfoque..........................................51

4.3.4. La Reserva Tributaria ....................................................................53

5. Evaluando la viabilidad de la actuación del Estado ..................................54

6. Temas pendientes..............................................................................................57

CONCLUSIONES Y RECOMENDACIONES..................................65 


\section{INDICE DE TABLAS}

Tabla 2.1.Convenios Internacionales y las modalidades de Intercambio de

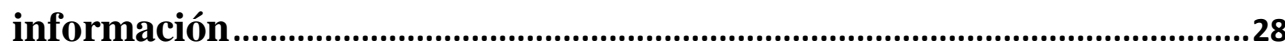

Tabla 3.1.Principales modelos de convenios de intercambio de información y los derechos de los contribuyentes ..........................................................................38

Tabla 4.1. Modalidades de intercambio en los convenios celebrados por el Perú.42 


\section{INDICE DE FIGURAS}

Figura 2.1.Marco Básico del Common Reporting Standard .........................................25

Figura 3.1.Protección de la base tributaria vs. Derechos de los contribuyentes .....31

Figura 4.1.Inversiones Peruanas en el extrnajero ........................................................40

Figura 4.2.Participación en la Recaudación - Contribuyentes .......................................41 


\section{INDICE DE ANEXOS}

Anexo I Intercambio de Información en Convenios suscritos por el Perú -

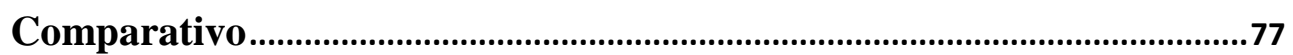




\section{INTRODUCCIÓN}

El objeto de la imposición en un sistema tributario que aspira a la justicia, a la par que cumplir con sus objetivos de carácter financiero, es que los contribuyentes tributen en función a su capacidad contributiva determinada conforme a los criterios de imposición establecidos en el ejercicio de la potestad tributaria de un Estado, la cual en nuestra legislación tratándose de sujetos domiciliados en el país, involucra su riqueza o su patrimonio de manera global, es decir de carácter mundial.

La era de la globalización e internacionalización ha dado paso al crecimiento de actividades transfronterizas: movimiento de capitales, de bienes, servicios y personas, lo cual aunado al avance tecnológico permiten la deslocalización de las operaciones y la generación de rentas y gastos, así como la tenencia de patrimonio en el extranjero; de tal suerte que es muy fácil trasladar ingresos o rentas a jurisdicciones diferentes atendiendo a distintos criterios como es el minorar la carga impositiva, con lo que se afectan las bases fiscales llegando incluso a producirse situaciones de fraude fiscal.

Es así que la labor de la Administración Tributaria estriba en determinar la correcta obligación tributaria a cargo de los contribuyentes y verificar su cumplimiento, para lo cual debe enfrentar el reto de lograr esta determinación en función a bases imponibles globales pero ejerciendo competencias dentro de una jurisdicción de ámbito nacional, pues las circunstancias antes descritas, ponen a prueba las reglas de las jurisdicciones locales en cuanto a su derecho a gravar determinado supuesto y estimar la cuantía del gravamen correspondiente.

Es en este contexto de una economía globalizada y de auge de los negocios internacionales, que a nivel mundial se ha gestado un movimiento de cooperación entre los estados sin precedentes en el cual se ha considerado el intercambio de información tributaria como una herramienta indispensable para el accionar de las Administraciones Tributarias a efecto de lograr el cumplimiento tributario y prevenir la evasión fiscal.

En su nivel más amplio, el intercambio de información entre Administraciones Tributarias de diferentes países implica la dación recíproca de información de carácter económico y financiero de interés fiscal, ya sea de un contribuyente específico, o de un grupo de contribuyentes, o sectores o actividades económicas e, incluso, información referida a determinados tributos o sistemas de imposición. 
Estando frente a jurisdicciones diferentes en las que se ejercen distintas soberanías, este intercambio de información sólo puede darse en virtud de un acuerdo celebrado entre las jurisdicciones correspondientes, que las autorice a dicho propósito. Estos instrumentos de derecho internacional podrán ser de carácter bilateral o multilateral, dependiendo del número de jurisdicciones comprometidas en los mismos.

Ahora bien, a efecto de su implementación y ejecución es necesario tener en cuenta entre otros aspectos:

1. El marco jurídico dentro del cual el intercambio de información se llevará a cabo, es decir los términos del acuerdo; los derechos y deberes entendidos como las responsabilidades de los participantes, en virtud de los cuales por ejemplo se debe respetar la confidencialidad de la información que se obtenga y el uso que se le debe dar a la misma; es decir si deberá ser utilizada exclusivamente para fines fiscales o podrá ser usada para otros fines.

2. La infraestructura del país y de la Administración, en cuanto al sustrato de la ejecución del acuerdo, referido al componente legal, procedimental, tecnológico de su implementación; es decir, entendida como la capacidad de un país para cumplir con cualquier compromiso asumido de intercambiar información.

En lo relativo al marco legal dentro del cual el intercambio de información se llevará a cabo, se debe analizar si en nuestro país se presenta algún impedimento en tanto dicho intercambio involucraría información que se encuentra referida en algunos casos al ámbito de la intimidad personal, lo cual tiene implicancia en los derechos fundamentales de la persona consagrados en nuestra Constitución Política, por lo que en virtud de lo dispuesto en sus artículos $55^{\circ}, 56^{\circ}$ y $57^{\circ}$, la Ley N. ${ }^{\circ} 26647^{1}$ que regula los actos relativos al perfeccionamiento nacional de los Tratados celebrados por el Estado Peruano y el Reglamento del Congreso de la República se requeriría el cumplimiento de un procedimiento constitucional - administrativo para la suscripción de los acuerdos correspondientes.

En este contexto el trabajo a desarrollar resulta de sumo interés y actualidad toda vez que a la fecha el Estado Peruano se encuentra abocado a cumplir con los estándares internacionales en materia de transparencia fiscal internacional a efecto de su incorporación a la Organización para la Cooperación y el Desarrollo Económicos (OCDE). Es así que en el mes de diciembre de 2014 el Gobierno del Perú suscribió con

\footnotetext{
${ }^{1}$ Publicada el 28.06.1996.
} 
la referida organización, un Acuerdo de Cooperación y un Memorando de Entendimiento ${ }^{2}$ formalizando el marco para el desarrollo de las relaciones entre ambas partes así como el Programa País, a fin de incorporar al Perú como miembro pleno en dicha organización en el 2021.

Los documentos antes mencionados, consideran una serie de objetivos y actividades tales como revisiones y estudios, participación en Comités al interior de la organización, así como adhesiones a instrumentos legales y jurídicos de la misma, como es el caso de la Convención Multilateral sobre Asistencia Administrativa Mutua en Materia Fiscal (CAMMT), que constituye uno de los instrumentos más importantes a nivel mundial para efectivizar el intercambio de información.

En ese sentido, resulta de interés analizar la normativa peruana que regula instituciones tales como el secreto bancario o la reserva tributaria en el contexto antes mencionado. El trabajo a desarrollar se enmarca en la revisión de la doctrina internacional sobre el intercambio de información y en el análisis del sustrato legal que se requiere para ejecutar el intercambio de información de manera eficaz de tal forma que coadyuve al cumplimiento tributario y a la recaudación efectiva. Así por ejemplo, se considera que el estándar internacional sobre intercambio de información para poder aplicarse requiere la implementación de procedimientos que tengan en cuenta aspectos tales como la protección del derecho a la intimidad y privacidad, el derecho a la defensa del contribuyente, la posibilidad de impugnar el intercambio mismo, entre otros aspectos a fin de que el procedimiento se realice de manera fluida y eficaz, de tal manera que la información obtenida mediante el intercambio pueda utilizarse de manera efectiva en los procesos tributarios vinculados a la determinación y recaudación que correspondan.

Si bien en las recientes modificaciones introducidas a la legislación tributaria se ha buscado adecuar nuestra normativa a fin de encontrarnos en aptitud de poder realizar intercambios de acuerdo a los estándares internacionales, consideramos que aún se requieren algunos ajustes para que este no vulnere derechos de los ciudadanos y pueda resultar efectivo para las labores de las Administraciones Tributarias involucradas.

En tal sentido, se identificarán las adecuaciones que ameriten efectuarse a nuestro sistema legal y, los procedimientos de la propia Administración que permitan la celebración e implementación de los acuerdos correspondientes y, estar en aptitud de realizar un efectivo intercambio de información.

${ }^{2}$ Ratificado mediante Decreto Supremo N. ${ }^{\circ}$ 004-2015-RE, publicado el 11.2.2015. 


\section{CAPITULO I: LOS ACUERDOS DE INTERCAMBIO DE INFORMACIÓN}

El intercambio de información tributaria entre los Estados es un mecanismo de carácter internacional, pues involucra a diferentes jurisdicciones, es decir Estados con sus respectivas soberanías y los principios que las regulan que se manifiestan en sus potestades y competencias; en tal sentido a efecto de su ejecución se requiere de la existencia de un convenio o tratado internacional, que es el mecanismos a través del cual se regulan las relaciones entre los Estados de manera formal y oficial, más aún cuando en el presente caso estamos frente a un mecanismo que debe observar una serie de reglas al encontrarse referido a aspectos y materias que involucran derechos de los ciudadanos que se encuentran protegidos legalmente, incluso en algunos casos por normas de rango constitucional .

\subsection{Definición y Naturaleza}

Conforme a la doctrina, los tratados vienen a ser convenios o acuerdos entre Estados soberanos de carácter vinculante. El Artículo 2 de la Convención de Viena sobre el Derecho de los Tratados (1969) establece que se entiende por "tratado" a un acuerdo internacional celebrado entre Estados de manera escrita, independientemente de la denominación que se le de, y que se encuentra regulado por el derecho internacional público.

En sus inicios los tratados en materia de tributación internacional, tenían como principal objetivo - por no decir el único - el evitar la doble imposición, fenómeno que se produce cuando un mismo sujeto resulta afecto a imposición por la misma renta o patrimonio en más de una jurisdicción; así el tratado establece las reglas que se tendrán en cuenta a fin de identificar al Estado que tendrá el derecho a gravar determinadas operaciones o situaciones; en tal sentido constituyen una especie de, como señala Calderón (2008), "pactos de reparto del poder tributario" (p.43), dado que establecen 
limitaciones a la potestad tributaria de los Estados. Así el Intercambio de Información inicialmente se encontraba regulado en una de las cláusulas de los Convenios para evitar la Doble Imposición (CDI) en lo que la doctrina ha denominado "cláusula de intercambio limitada", en tanto solo estaba referida a lo dispuesto en el convenio.

Con el devenir y el incremento del comercio transfronterizo, el avance tecnológico, las crisis económicas de alcance mundial y la evolución de las relaciones entre los Estados, así como la importancia que internacionalmente ha adquirido el aspecto fiscal en los últimos tiempos y, la relevancia que se ha dado a la información para fines que trascienden lo estrictamente tributario, que tal como se ha señalado es para lo que fueron concebidos originalmente los CDI, el objetivo de los convenios o tratados internacionales en materia tributaria evolucionó a aspectos más amplios vinculados con la seguridad y el desarrollo económico de los Estados, a fin de garantizar la mayor colaboración entre los mismos en el combate contra el problema de la erosión de las bases fiscales ocasionada por la evasión fiscal, motivo por el cual se han desarrollado instrumentos que regulan específicamente la materia, denominados “Acuerdos sobre intercambio de información”.

Así, uno de los mecanismos ${ }^{3}$ para llevar a cabo este combate es el intercambio de información, de tal manera que le permita a las Administraciones Tributarias de los Estados involucrados encontrarse en aptitud de poder determinar las obligaciones a cargo de los sujetos a imposición en sus jurisdicciones conforme a su real capacidad contributiva.

Es así que el fundamento de estos instrumentos jurídicos es la tutela del interés fiscal, es a decir de Rosembuj, T. (2004) "el respeto al derecho a la recaudación tributaria por parte de cada Estado como pieza estable de su orden público económico” (p.13).

Ahora bien, en cuanto a su finalidad podemos decir que esta reside en recibir y suministrar de manera mutua - pues no puede ser de manera unilateral ${ }^{4}$ sin que medie un compromiso de carácter recíproco ${ }^{5}$ - información, datos o documentos sobre actos, operaciones, patrimonios, ingresos o bienes que sean de utilidad para los sistemas tributarios involucrados.

\footnotetext{
${ }^{3} \mathrm{~A}$ la fecha existen otros tipos de colaboración tales como las fiscalizaciones conjuntas o en la recaudación de adeudos tributarios, pero que no son materia de análisis en el presente trabajo.

${ }^{4}$ No obstante veremos más adelante que, aún cuando es cuestionable, existen algunos casos en los que no se da la reciprocidad, como es lo que ocurre en uno de los modelos de la Ley de Cumplimiento Tributario de Cuentas Extranjeras - FATCA.

${ }^{5}$ Se debe tener en cuenta que el principio de reciprocidad es el que sustenta toda la teoría de la asistencia y cooperación internacional.
} 
Cabe indicar que si bien estos instrumentos son de carácter internacional, una vez suscritos y conforme al procedimiento establecido por el ordenamiento legal de cada Estado, pasarán a formar parte del mismo, y su jerarquía dependerá de lo dispuesto en las normas constitucionales respectivas.

Los tratados pueden ser de carácter bilateral o multilateral, dependiendo de las jurisdicciones que intervengan. Al respecto y atendiendo al avance en materia de cooperación y colaboración internacional, nos inclinamos por considerar como más recomendables los multilaterales, pues tienen la ventaja de comprometer a un amplio número de países bajo un mismo instrumento, de tal manera que con su suscripción se amplía el ámbito del control sobre el fraude fiscal y se manejan conceptos y definiciones estandarizadas con lo que se reducen las discrepancias respecto a la interpretación de los mismos, a la par que se manejan mecanismos homologados que permiten fluidez en la transmisión de la información materia del intercambio, asegurándose así su efectividad.

Si bien la mayoría de acuerdos existentes sobre la materia son de carácter bilateral, y en un inicio la OCDE recomendaba que así fueran, pues consideraba que esta modalidad contemplaba de mejor manera la realidad y necesidades de los países dada su especificidad; en la actualidad este organismo promueve el desarrollo de instrumentos de alcance multilateral como se puede apreciar en la Acción 15 del Proyecto sobre Erosión de la Base Imponible y el Traslado de Beneficios (Plan BEPS ${ }^{6}$ ) referida a la promoción de la suscripción de la Convención Multilateral de Asistencia Mutua en Materia Fiscal (CAMMT).

Ahora bien, pasando a la parte operativa, es del caso señalar que en la actualidad existen dos modelos de convenios que han sido elaborados por organismos internacionales como son la OCDE y la Organización de las Naciones Unidas (ONU), para ser utilizados como referencia en las negociaciones que se lleven a cabo, es decir son instrumentos del denominado soft-law que por sí mismos no constituyen instrumentos de carácter vinculante, pero que han articulado las consideraciones mínimas en relación a derechos y obligaciones que los Estados deben asumir para efecto de realizar un Intercambio de Información efectivo.

\subsection{Objeto del intercambio}

\footnotetext{
${ }^{6}$ Por las siglas de su denominación en inglés "Base Erosion and Profits Shifting”.
} 
Si bien el objeto del intercambio siempre será información, el contenido de la misma es el que ha sufrido modificaciones conforme ha evolucionado el concepto de cooperación internacional en materia tributaria.

En principio debemos entender como "información” en su sentido más amplio, y tal como lo ha definido la OCDE, en el artículo 1 y en el inciso m) del artículo del Modelo de "Convenio para evitar la doble imposición respecto a los impuestos sobre la Renta y el Patrimonio", "a todo dato, declaración, documento, cualquiera sea la forma que revista, necesario para la administración y aplicación de las legislaciones tributarias de las Partes.".

Así tenemos que en un inicio el principal objeto de los intercambios era la información referida a los tributos sobre la renta y el patrimonio, pues como hemos visto, este mecanismo tuvo su origen en el marco de la suscripción de los CDI en materia de los referidos tributos; no obstante, con el devenir y la aparición de nuevas figuras y cambios en el entorno tributario internacional, el alcance de este mecanismo se amplió a otros tributos, considerando tanto a los impuestos directos como a los impuestos indirectos ${ }^{7}$, con la única excepción de los tributos arancelarios ${ }^{8}$, tal como se puede apreciar en lo dispuesto en el artículo 26 del Modelo de Convenio de la OCDE y en el artículo 2 de la CAMMT, incluso éste último instrumento puede aplicarse a contribuciones estatales, regionales y locales, incluyendo las contribuciones a la Seguridad Social.

Así se adoptó una modalidad más amplia de intercambio a fin de incluir la posibilidad de que los Estados pudieran considerar cualquier información de carácter fiscal, en la medida que resultara de previsible importancia para sus administraciones tributarias y la recaudación de los tributos.

La actual normativa internacional alude al concepto de "información previsiblemente relevante" en sustitución del anterior referido a "información necesaria" - de acuerdo a la doctrina califican como conceptos jurídicos indeterminados-, si bien algunos consideran que en realidad ambos términos pueden entenderse de igual manera, la OCDE ha señalado que la modificación busca establecer un intercambio de información tan amplio como sea posible en tanto resulte de utilidad para la aplicación de los tributos o ejercer el

\footnotetext{
${ }^{7}$ Como es el caso del sistema VIES respecto al Impuesto al Valor Añadido en la Unión Europea, que es un sistema de almacenamiento e intercambio de información específica para el control de las operaciones intracomunitarias.

${ }^{8}$ Puesto que tienen sus propias regulaciones, instrumentos y mecanismos en el ámbito internacional.
} 
control que corresponde sobre un contribuyente. Al respecto, se considera pertinente lo señalado por Patón García (2011) en cuanto a que esa sustitución de términos

incorpora un criterio de ponderación y, por ende, la discrecionalidad que en todo caso la Administración tributaria de cada Estado contratante debe conservar en orden al principio de autonomía procedimental, o si se prefiere, estamos ante un estándar internacional que circunscribe y delimita “ la zona media entre el límite máximo y mínimo” en la práctica del intercambio de información (págs.. 198-199)

En tal sentido, se debe tener en cuenta que el pedido deberá encontrarse debidamente sustentado por cuanto si bien la Administración cuenta con facultades discresionales, estas no pueden ser arbitrarias, adicionalmente al hecho que se busca evitar las denominadas "fishing expeditions" o "expediciones de pesca", en las cuales se realizan solicitudes de información que no tienen un objetivo claro y definido basadas en algún indicio o proceso en curso. No obstante, se admite que procede la entrega de información cuando se precise que la relevancia de la misma solo será posible determinarla luego del análisis correspondiente. En todo caso, no se debe perder de vista el objetivo último del intercambio de información, que es el proporcionar a los Estados información que le permita lograr los ingresos que corresponden conforme a su sistema impositivo.

Lo que subyace en la obtención de información y en el intercambio de información es el deber de contribuir al sostenimiento del gasto público del Estado de acuerdo a la capacidad contributiva de los sujetos, así como coadyuvar en la lucha contra el fraude fiscal del Estado solicitante.

Para que los intercambios se consideren efectivos, la información debe estar disponible, entendiendo como tal tanto a la que obra en poder de la autoridad tributaria como aquella que no estándolo, puede ser obtenida conforme a los procedimientos contemplados en la legislación interna del Estado requerido.

\subsection{Modalidades de Intercambio de Información}


Estando a la forma en que se inicia el procedimiento de Intercambio de Información y a los mecanismos a través de los cuales se efectiviza, existen tres modalidades ${ }^{9}$ que a continuación se detallan:

\subsubsection{Intercambio a Requerimiento}

Denominado también como Intercambio de información Específico o a solicitud, de acuerdo a la definición de la OCDE (2006) el intercambio de información a requerimiento se refiere a aquella situación en la cual la autoridad competente de un país solicita información particular a la autoridad competente de otro país que es parte de un tratado o convenio; es decir consiste en el intercambio de información entre dos estados que tienen suscrito un convenio o tratado para tal efecto, a raíz del pedido o solicitud que realiza uno de ellos de manera expresa sobre un contribuyente en específico e individualizado y respecto de un caso concreto.

En este tipo de intercambio no están permitidos los requerimientos de información genéricos o las denominadas "expediciones de pesca" o "fishing expeditions" antes mencionadas, debiendo proporcionarse información pertinente, incluida la bancaria o la fiduciaria independientemente de un interés fiscal o la aplicación de un estándar de doble incriminación, es decir que no se requiere que la conducta investigada constituya un ilícito de acuerdo a la legislación interna del Estado requerido.

El pedido debe ser atendido, aún cuando la información solicitada no se encuentre en poder de la autoridad competente del Estado requerido, en cuyo caso este deberá realizar las acciones conducentes a su obtención conforme a su legislación interna, incluso si la información no le resultare de utilidad para sus propios intereses y tampoco se podrá aducir razones de imposibilidad por la existencia de instituciones jurídicas tales como el secreto bancario o la reserva tributaria.

Es el método que más aceptación tiene, pues se considera que es el más equilibrado ya que respeta el principio de proporcionalidad, que de acuerdo a lo señalado por Rodríguez Bereijo (2012) establece que “el número y la naturaleza de las solicitudes de información efectuadas en un determinado periodo no impongan una carga administrativa desproporcionada a la autoridad requerida" (p.11).

\footnotetext{
${ }^{9}$ Algunos consideran que existen otras modalidades como sería la realizada con motivo de las auditorías simultáneas; no obstante es ampliamente aceptada en la doctrina que las principales son las tres modalidades que se analizarán en el presente trabajo, siendo las demás derivadas de estas.
} 
Así mismo, esta modalidad debe sujetarse al principio de subsidiaridad, dado que la autoridad solicitante debe, previamente a la formulación del requerimiento, haber agotado infructuosamente todas las formas de obtener la información de manera directa.

En el Reporte del Peer-review del Foro Global de Transparencia e Intercambio de Información para efectos fiscales que la OCDE publicó a inicios del 2016, se puede apreciar que desde el 2010 esta modalidad de intercambio se ha incrementado en un 60\%, y son 130 países los comprometidos a realizar este tipo de intercambio de información; sin embargo, se espera que continúe aumentando su uso con la implementación del nuevo estándar de intercambio automático, dado que este último servirá de herramienta de detección y será a través del intercambio a requerimiento que se podrá profundizar en la obtención de información mucho más precisa respecto a un determinado contribuyente, a fin de construir los casos contra los incumplidores.

\subsubsection{Intercambio Espontáneo}

Se denomina Intercambio espontáneo a la modalidad mediante la cual los Estados "de oficio" se transmiten información que puede resultarles de relevante interés, que hubieran identificado en el ejercicio regular de sus funciones de administración de su propia legislación tributaria; es decir sin que previamente medie solicitud o pedido alguno entre ellos.

Esta modalidad de intercambio se produce generalmente en el marco de un acuerdo de cooperación internacional y en base al compromiso y la activa participación de los funcionarios de las administraciones tributarias involucradas.

En este contexto, resulta procedente el Intercambio Espontáneo cuando se presenten y detecten situaciones en las que se pueda suponer que podría existir algún incumplimiento de carácter tributario en el estado receptor de la información, por ejemplo: casos en que el residente de un país ha recibido pagos de residentes de otro país, goce de exenciones o beneficios de impuestos en un país a efecto que se pague el impuesto en otro país, operaciones entre empresas vinculadas o pertenecientes al mismo grupo económico cuando se presuma que el objeto de las mismas es transferir beneficios por tratamientos fiscales más beneficiosos, casos de planificaciones agresivas, entre otros.

Con relación a las demás modalidades de intercambio de información podernos señalar que el intercambio espontáneo tiene mayor eficacia que el intercambio automático, dado que la información transmitida es más acotada y específica, 
adicionalmente al hecho de que ha sido de alguna manera evaluada por personal especializado, auditores tributarios en el ejercicio de sus labores de fiscalización o investigación tributaria, quienes han determinado que cierta información resulta de utilidad para el otro estado.

Ahora bien, el principal inconveniente, aunque no de difícil solución, es la discrecionalidad que puede existir en el funcionario que detecte estos casos en cuanto a reportar la información, dado que esto genera el inicio de un procedimiento que insume el recurso muchas veces escaso de los auditores: el tiempo; sabido es en las administraciones tributarias que normalmente las auditorías y revisiones correspondientes a los casos que le han sido asignado a un funcionario, llámese auditor o agente fiscalizador, deben ser culminadas en un tiempo establecido, por lo que reportar situaciones para ser materia de intercambio de información puede no resultar atractivo por el tiempo que les demande. No obstante, esto se puede superar si la administración establece algún tipo de incentivo para los casos en que se reporte información para ser intercambiada y que resulte de utilidad para la administración tributaria del país receptor, así como considerar el diseño de procedimientos agiles que no disuadan al funcionario de detectar e informar la existencia de información valiosa para otra administración y que reduzcan su discrecionalidad.

\subsubsection{Intercambio Automático}

El Intercambio Automático es cuando la información referida a un determinado grupo o categoría de contribuyentes u operaciones se transmite entre administraciones de manera sistemática. En esta modalidad la información a ser materia de intercambio es preestablecida y estandarizada, así como la periodicidad de su envío.

Cabe indicar que la transmisión de información es de manera masiva; es decir no de una persona determinada o en específico, que previamente se ha considerado importante a efecto de identificar aquella información que resulte de un interés previsible concreto.

En el Intercambio Automático de Información los conceptos a ser transmitidos corresponden a diversas categorías que son gestionadas por la autoridad fiscal como por ejemplo: dividendos, intereses, regalías, salarios, pensiones, cambios de residencia, devolución del impuesto al valor agregado, etc..

La información es intercambiada entre las autoridades fiscales de los países que hubieran suscrito un acuerdo y tiene como objetivos: 
a) Que el país de residencia del contribuyente pueda revisar sus registros para verificar que los ingresos y/o activos del exterior hayan sido debidamente reportados.

b) Generar un efecto disuasivo y, por ende el cumplimiento voluntario.

De esta manera se propende a permitir que los Estados puedan recuperar los ingresos fiscales "perdidos”, y fortalecer más aún los esfuerzos internacionales para aumentar la transparencia, la cooperación y la rendición de cuentas entre las instituciones financieras y las administraciones tributarias. Además, esta modalidad tiene la ventaja de generar beneficios secundarios al incrementar revelaciones voluntarias de activos ocultos y alentar a los contribuyentes a reportar toda la información pertinente.

Como se comentara con anterioridad, la nueva información que se evidencia o “sale a la luz" mediante el intercambio automático, puede generar la realización de un Intercambio a Requerimiento, por lo que las dos modalidades son complementarias, y su empleo conjunto puede mejorar la eficacia de los acciones de las Administraciones Tributarias.

Aunque es muy pronto para afirmarlo, pues aún no existe información estadística suficiente que lo sustente, algunos especialistas consideran que es la modalidad más eficaz para la lucha contra la evasión tributaria o la planificación tributaria agresiva; pues por un lado está la inmediatez con la que se obtiene la información y con la que se puede procesar considerando que se encuentra estandarizada, lo cual facilita la detección de la omisión de la obligación tributaria y, por ende su recaudación - existe una relación directa entre el tiempo que transcurre entre la determinación de la deuda y su recuperación ${ }^{10}$-; y de otro lado no se puede negar el efecto disuasivo o preventivo que tiene, dado que el conocimiento de la existencia de este procedimiento actúa como un elemento de riesgo para el contribuyente en la configuración de sus operaciones.

Es así que para hacer frente con mayor capacidad a la evasión de impuestos y reducir al mínimo los costos para los gobiernos y las empresas, se ha creado un único estándar global de intercambio automático, respecto de la información de la cuentas financieras, la "Norma para el intercambio automático de información de las cuentas financieras en el ámbito fiscal” o "Common Reporting Standard” (CRS).

\footnotetext{
${ }^{10}$ Se ha demostrado que cuanto más demore la determinación de la deuda y su cobranza, más difícil se torna su recuperación.
} 


\section{Capítulo II: EL INTERCAMBIO DE INFORMACIÓN EN EL PANORAMA INTERNACIONAL}

La era de la globalización e internacionalización ha dado paso al crecimiento de actividades transfronterizas: movimiento de capitales, de bienes, servicios y personas; circunstancias que han puesto a prueba las reglas de las jurisdicciones locales en cuanto a su derecho a gravar un supuesto concreto y determinar la cuantía del gravamen ${ }^{11}$.

En principio, cada jurisdicción es soberana, esto es, tiene la potestad de dictar sus propias normas y hacerlas cumplir hasta donde alcancen sus fronteras. Sin embargo, debido a la mayor interacción entre los agentes económicos de diferentes países, fortalecido por el rápido desarrollo de las tecnologías de la información en las últimas décadas, muchos contribuyentes "han cruzado" las fronteras y obtienen ingresos y/o activos en otras jurisdicciones $^{12}$, incluso sin haberse movido o trasladado físicamente a otro país, literalmente sin que "hayan puesto un pie fuera" de sus países de residencia.

Ahora bien, una jurisdicción para poder determinar correctamente si puede o no gravar cierto supuesto así como determinar su cuantía, necesita información, la cual no siempre se encuentra a su disposición, por lo que resulta vital el establecer mecanismos, canales y contactos que permitan su obtención de manera que se asegure su procedencia técnica y legal para asegurar su uso efectivo; es entonces en estos casos donde el intercambio de información tributaria entre jurisdicciones cobra importancia.

Es así como en el marco del Derecho Internacional, la cooperación y coordinación entre jurisdicciones resulta indispensable para la implementación de acuerdos e instrumentos jurídicos de carácter vinculante, esto es, normas que no obstante no haber sido dictadas por el legislador de cada estado, son obligatorias y forman parte del sistema legal del estado que las ratifica.

De este modo, en el Derecho Tributario Internacional se han elaborado diversos modelos $\mathrm{y}$ acuerdos que han ido evolucionando y, que brindan el sustento legal y la forma en que

\footnotetext{
${ }^{11}$ El libre movimiento de capitales, bienes, servicios y personas son las cuatro libertades fundamentales sobre las que descansa el mercado único de la Unión Europea, cuya finalidad es la remoción de barreras entre los estados miembros y así facilitar las operaciones transfronterizas entre los estados miembros. En nuestra opinión, en cuanto al plano internacional estas cuatro libertades son básicas en las operaciones transfronterizas y no deberían ser sujetas a restricciones ilegitimas. Four Freedoms. Eu ABC.com. Recuperado el 15 de enero de 2017, de http://en.euabc.com/word/506

12 Debido a los avances en las tecnologías de la información, ya no se necesita "cruzar" las fronteras físicamente para poder interactuar con los agentes económicos de otras jurisdicciones, o tener presencia en diferentes mercados o economías de otras jurisdicciones.
} 
se debe ejecutar esta cooperación y coordinación materializada, específicamente en el intercambio de información.

Así tenemos entre los principales, atendiendo a su uso a nivel mundial, el Modelo de Convenio para evitar la doble imposición respecto a los impuestos sobre la Renta y el Patrimonio de la OCDE, la Convención modelo de las Naciones Unidas sobre la doble tributación entre países desarrollados y países en desarrollo, la Convención Multilateral sobre Asistencia Administrativa Mutua en Materia Fiscal - CAMMT, la Ley de Cumplimiento Tributario de Cuentas Extranjeras -FATCA ${ }^{13}$ y los acuerdos específicos de intercambio información tributaria.

\subsection{EI Modelo OCDE}

El Modelo de Convenio para evitar la doble imposición respecto a los impuestos sobre la Renta y el Patrimonio de la Organización para la Cooperación y el Desarrollo Económico (MOCDE), es el modelo más conocido y utilizado a nivel mundial. Este modelo se remonta al año 1963 y ha sido objeto de diversas revisiones, siendo la última versión el MOCDE del año $2014^{14}$.

Los impuestos cubiertos por este modelo son los impuestos sobre la renta y el patrimonio que los estados contratantes imponen a las personas residentes en los mismos. De acuerdo a lo previsto en los artículos del 1 al 3 del MOCDE, se entiende por "persona" tanto a las personas físicas como a las jurídicas consideradas como tales para efectos tributarios.

En el capítulo VI del MOCDE denominado "Provisiones Especiales", se encuentra el artículo 26 que regula lo relacionado al intercambio de información tributaria. El objetivo original de este artículo era facilitar un mecanismo para la correcta aplicación de los CDI y así evitar la doble imposición.

\subsubsection{Breve reseña del artículo 26 del MOCDE}

El artículo 26 del MOCDE del año 1963 constaba sólo de dos numerales y estaba restringido en el ámbito subjetivo, es decir respecto de quienes se aplicaba, por el artículo 1 del MOCDE. En consecuencia la información intercambiable sólo podía estar referida

\footnotetext{
${ }^{13}$ Por las siglas de su denominación en inglés "Foreign Account Tax Compliance Act".

${ }^{14}$ Esta última versión solo se encuentra disponible en dos idiomas: inglés y francés. Ver:http://www.oecdilibrary.org/taxation/model-tax-convention-on-income-and-on-capital-condensed-version_20745419
} 
a aquellos individuos residentes de los estados contratantes; así mismo existía otra restricción respecto a los impuestos que se encontraban dentro de su ámbito de aplicación conforme lo disponía el artículo 2 del MOCDE.

Sin embargo, posteriormente de acuerdo a la versión MOCDE de 1977, la información intercambiable ya no estaba restringida por el mencionado artículo 1, por lo que la solicitud de información se puede referir a terceros no residentes, a condición de que exista una conexión directa entre el estado solicitado y el no residente.

Así por ejemplo, estando a lo comentado por Debelva y Diepvens (2016), si el estado A solicita información al estado B sobre una cuenta bancaria abierta por el residente $\mathrm{X}$ del estado $\mathrm{C}$, el estado $\mathrm{B}$ no puede declinar la solicitud del estado $\mathrm{A}$ sustentando que $\mathrm{X}$ no es residente de ninguno de los estados contratantes (A y B) (p. 298).

Por otra parte, mediante una adición practicada en el año 2000, se amplió la cobertura de los impuestos involucrados, ya que se estableció que su aplicación no estaba limitada por el artículo 2 del MOCDE; esto es, que se puede intercambiar información sobre otros impuestos distintos a los de Renta y Patrimonio, como por ejemplo, los impuestos sobre las ventas. No obstante, no se encuentra restringida la posibilidad de que los estados contratantes sí limiten la aplicación del artículo 26 al artículo 2 del $\mathrm{MOCDE}^{15}$.

A partir del año 2002, el Comité en Asuntos Fiscales de la OCDE realizó una profunda revisión del citado artículo, tomando en cuenta las prácticas de los estados, las propuestas del "Acuerdo Modelo de la OCDE sobre Intercambio de Información en Materia Tributaria" desarrolladas por el Grupo de Trabajo del Foro Global de la OCDE para el Intercambio de Información, así como el reporte sobre "Mejora del acceso a la información bancaria con fines fiscales".

Esta revisión se reflejó en la versión del MOCDE del año 2005, cuyas principales innovaciones fueron:

i) En cuanto a la información materia de intercambio se modificó los términos "necesaria" por "previsiblemente relevante" en el numeral 1. De este modo, se amplía la aplicación del artículo 26, ya que no solo será materia de intercambio la información que se considere "necesaria", debiendo demostrar

\footnotetext{
${ }^{15}$ OECD. (2014). Commentary OECD. Recuperado el 15 de enero de 2016, de http://www.keepeek.com
} 
tal condición, sino también la que se considere "previsiblemente relevante", con lo cual se relativiza el requisito ${ }^{16}$. Cabe indicar, que en los comentarios al MOCDE se indica que esta modificación no implica un cambio sustancial, pues sólo se pretendía asegurar la correcta aplicación del convenio. De opinión diferente, y con la cual coincidimos, es el maestro Rosembuj (2004), para quien dicho cambio si implica uno sustancial dado que indica que se pasa de una situación jurídica subjetiva fuerte (información necesaria) que consideraría la existencia de un hecho lesivo para el interés fiscal del estado, a una situación jurídica subjetiva débil (información previsiblemente relevante) que no prejuzga tal daño al estado.

ii) Se adicionó el numeral 4, de acuerdo al cual se establece la obligación del Estado requerido a suministrar la información aun si no existiera interés fiscal propio.

iii) Se agregó el numeral 5, conforme al cual el Estado requerido no puede negar el suministro de la información aduciendo que dicha información se encuentra en manos de alguna institución financiera y, por ende protegida por el secreto bancario.

Posteriormente, en el MOCDE del 2012 se modificó el numeral 2 del artículo 26 para permitir que las autoridades competentes puedan utilizar la información recibida para otros propósitos; esto es, no exclusivamente tributarios, siempre que se pruebe que tal uso no violenta normas de ninguno de los Estados contratantes. De otro lado, con el fin de precisar la aplicación del numeral 1, los comentarios al MOCDE 2012 incluyeron la prohibición de las denominadas "fishing expeditions", es decir la prohibición de realizar investigaciones genéricas; sin perjuicio de un mayor desarrollo en las siguientes líneas, cabe indicar que esta postura ha sido muy criticada pues no se tiene muy claro el real alcance del mismo tal como lo indican Debelva y Diepvens (2016).

Asimismo, conforme a esta versión, los estados firmantes no pueden excusarse en el secreto bancario para rechazar solicitudes de información.

\subsubsection{El artículo 26 en el MOCDE 2014}

\footnotetext{
${ }^{16}$ Teniendo en consideración lo señalado en el numeral 2 del Capítulo I del presente trabajo.
} 
El actual texto del artículo 26 del MOCDE prescribe el intercambio de información entre las autoridades competentes de los estados contratantes en dos situaciones:

i) La información debe ser intercambiada en cualquier caso en que previsiblemente exista una de las circunstancias que active las provisiones del tratado.

ii) La información debe ser intercambiada cuando es relevante para la administración y, exigencia de lo dispuesto en la legislación nacional de los estados contratantes respecto de los impuestos de toda clase y naturaleza percibidos por los estados contratantes.

Cabe indicar que conforme al Glosario de Términos Tributarios de la OCDE, un impuesto es "aquel pago obligatorio sin contraprestación en favor del gobierno"; aunque debe indicarse que conforme al numeral 5.5. de los comentarios al artículo 26 del MOCDE 2014, si bien la aplicación de dicho artículo no está limitada por el artículo 2 del MOCDE, el mismo no aplica respecto a derechos arancelarios, ya que aquellos se regulan por instrumentos legales más especializados.

Ahora bien, conforme a la versión MOCDE 2012, está prohibido realizar investigaciones genéricas "fishing expeditions", pues la información a solicitar debe estar referida a un caso concreto, identificando al sujeto y respecto de información previsiblemente relevante; sin embargo, no existe una definición en el MOCDE ni en sus comentarios sobre lo que se debe entender por " previsiblemente relevante", hecho que ha generado más de un problema, debido a que por la complejidad de las operaciones desarrolladas por las empresas resulta muy difícil demostrar la conexión entre el contribuyente y el estado contratante ${ }^{17}$.

En cuanto a los tipos de intercambio de información, el artículo 26 prevé tres tipos de intercambio: A solicitud, automático y espontáneo, pudiéndose combinar estos tres. Asimismo, se prevé otras herramientas tales como auditorías tributarias simultáneas.

De otro lado, cabe indicar que lo dispuesto en esta cláusula está regulado bajo el principio de subsidiariedad, de acuerdo con el cual el estado solicitante antes de requerir la información debe haber agotado todos los procedimientos internos para la obtención

\footnotetext{
${ }^{17}$ Debelva y Diepvens (2016) mencionan una caso entre el estado Francés y Luxemburgo, en el que la corte administrativa de Luxemburgo denegó otorgar la información sobre un contribuyente francés con cuentas en Luxemburgo, dado que la documentación enviada por el estado francés solo mostraba pagos de una compañía holandesa hacia otra en las Islas Vírgenes Británicas, que a su turno era una afiliada de la compañía francesa, siendo que las cuentas en Luxemburgo servían para hacer pagos a la compañía de las Islas Vírgenes Británicas.
} 
de la misma. Nuevamente, este es un punto materia de discusión, pues hay quienes realizan una interpretación estricta de este principio, mientras que otros autores indican que este principio aplicaría solo para el intercambio de información a solicitud, posición que compartimos atendiendo a las características de los otros tipos de intercambio, dado que en el intercambio espontáneo es el estado que proporciona la información el que realiza el análisis de la posible relevancia o pertinencia de la misma y, en el intercambio automático la información a reportar ha sido previamente acordada por los estados involucrados atendiendo a la importancia que para ellos representa; en cuanto al carácter subsidiario en ambos casos no es posible determinar si al momento de la entrega el otro estado se encontraba en aptitud o no de obtenerla por sus propios medios.

Asimismo, es del caso señalar que en esta cláusula se impone un deber de confidencialidad a los estados contratantes y, se contemplan los supuestos que habilitan a los estados a negarse válidamente a ejecutar el intercambio, tales como:

a) $\mathrm{Si}$ existe riesgo de revelar secretos industriales, de negocio, de comercio o profesionales o de procedimientos comerciales (numeral 4).

b) El tener que realizar medidas o prácticas administrativas contrarias a las contenidas en su legislación o en la del Estado solicitante.

\subsection{EI Modelo ONU}

La "Convención Modelo de las Naciones Unidas sobre Doble Tributación entre países desarrollados y países en vías de desarrollo" (MONU), tiene como origen las pautas desarrolladas por dicho ente en los años 80's a fin de evitar la doble imposición y la evasión tributaria. Este modelo si bien tiene una estructura similar al MOCDE, su principal diferencia radica en que presta atención a las necesidades de los países en vías de desarrollo que, a diferencia de los países desarrollados, son importadores de capital, pues desean atraer inversión extranjera y así lograr un mayor crecimiento económico y competitividad.

El artículo 26 del MONU, cuya versión actual data del año 2011, regula de manera amplia el intercambio de información entre los estados contratantes tanto para facilitar la aplicación del convenio, así como el cumplimiento de la legislación interna de los estados contratantes.

De este modo, el artículo enfatiza su carácter de herramienta para lograr eficiencia en el intercambio de información y, hace hincapié en su objetivo de prevenir 
la elusión y la evasión tributaria en contextos transfronterizos y la fuga de capitales con fines elusivos. De otro lado como señala Lang (2013), se destaca el rol de las autoridades tributarias, las cuales tienen la potestad para poder desarrollar e implementar de manera conjunta los mecanismos de información.

Asimismo, respecto al principio de reciprocidad se indica que, si bien los estados en vías de desarrollo suelen tener una capacidad administrativa menor frente a los estados desarrollados, ello no debe ser obstáculo para llevar a cabo el intercambio de información ${ }^{18}$.

En el texto del artículo 26 se adopta el término "previsiblemente relevante" que, conforme a los comentarios del MONU, debe entenderse como que no es imperativo que el estado solicitante demuestre la necesidad de la información antes de que surja la obligación de realizar el intercambio. Asimismo, como en el MOCDE el alcance de este artículo no está limitado por los artículos 1 y 2 del Convenio (sujetos e impuestos), más aún insta a las autoridades a compartir información no solo sobre sujetos sino también sobre técnicas para el análisis de riesgos, esquemas elusivos y evasivos, así como respecto de sectores de la actividad económica (minero, petrolero, gas, entre otros), con lo cual aborda de una manera más amplia el concepto de cooperación y coordinación internacional, con lo cual resulta mucho más interesante esta fórmula pues implica el intercambio de conocimientos y experiencias entre las diferentes administraciones tributarias.

De otro lado, también contempla la obligación de los estados contratantes de garantizar la confidencialidad respecto de la información materia de intercambio, sin perjuicio del uso de la misma para otros propósitos, pero con la previa autorización del estado solicitado. No obstante, se indica que esta obligación de confidencialidad no puede ser interpretada de manera absoluta de modo que entorpezca la finalidad del tratado, por lo que eventualmente la información podría utilizarse (y hacerse pública) ante las instancias judiciales o en la emisión de decisiones de las autoridades administrativas competentes. Sin perjuicio de la objeción de los estados contratantes de hacer pública la información ${ }^{19}$.

\footnotetext{
${ }^{18}$ Este punto no es muy claro en el MOCDE; esto es, si las administraciones de los estados contratantes deben tener la misma capacidad administrativa para el intercambio de información, por ejemplo países desarrollados frente a países en vías de desarrollo.

${ }^{19}$ MCONU 2011. p. 443.
} 
Por otra parte se establece la obligación de los estados contratantes de informar, dentro del plazo debido, sobre los cambios en su legislación o en sus prácticas administrativas que puedan implicar una contravención a lo dispuesto en el convenio, so pena de perder el derecho a presentar objeción alguna contra la provisión de la información.

Finalmente, de manera similar que en el MOCDE, en el MONU se contempla los tres tipos de intercambio de información, pero con una fórmula abierta, pues considera el intercambio a solicitud, el intercambio automático y "otras formas", entendiendo que incluye los intercambios espontáneos, así como que no limita la posibilidad de incluir otras modalidades que surjan en el futuro.

\subsection{Ley de Cumplimiento Tributario de Cuentas Extranjeras -FATCA}

La Ley de Cumplimiento Tributario de Cuentas Extranjeras -FATCA, emitida en el año 2010 por el gobierno de los Estados Unidos de Norteamérica, es un acuerdo con diversos estados alrededor del mundo, mediante el cual se requiere a las autoridades competentes de los estados firmantes, el intercambio automático de información sobre las cuentas en las instituciones financieras que residentes estadounidenses puedan tener en los citados estados.

La ley FATCA regula dos modelos de acuerdos intergubernamentales (AI), Modelo AI 1 y Modelo AI 2, cuya principal diferencia reside en el destinatario de la información. Bajo el Modelo AI 1 las instituciones financieras extranjeras comunican la información a sus agencias gubernamentales domésticas y, bajo el Modelo AI 2 las instituciones financieras extranjeras reportan la información directamente al servicio de recaudación de los Estados Unidos, es decir, al Internal Revenue Service (IRS).

Cabe indicar que la mayoría de países signatarios ha optado por el Modelo AI 1, por ejemplo Dinamarca, Finlandia, Croacia, Holanda, entre otros, incluso el Perú también ha escogido el Modelo AI 1, aunque actualmente solo es signatario pues se viene trabajando en la adecuación de la legislación nacional para tal fin. De otro lado, países como Japón, Hong Kong y Suiza se han alineado al Modelo AI 2.

El propósito de la ley FATCA es combatir la elusión tributaria obteniendo información sobre las cuentas y activos que los contribuyentes estadounidenses pudieran tener en el extranjero. De esta manera, la ley FATCA funciona como una herramienta de 
intercambio de información automático, pero a diferencia del AI 2 que si requiere reciprocidad para su implementación, el AI 1 funciona en una sola dirección, esto es, que el IRS no está obligado a reportar información a los otros estados informantes.

Ahora bien, la implementación de la Ley FATCA no ha estado exenta de críticas, pues mucho se ha cuestionado su carácter impositivo unilateral al afectar a ciudadanos y contribuyentes de otros estados mediante la imposición de obligaciones y de sanciones en caso de incumplimiento y, la posible vulneración a la privacidad de los contribuyentes norteamericanos.

Sin embargo, eso no ha sido impedimento para que esta ley sirva de base para el desarrollo de un modelo multilateral de intercambio de información; así en abril del 2013 Alemania, Reino Unido, Francia, España e Italia anunciaron que entre ellos adoptarían el intercambio de información en base al modelo FATCA.

Finalmente, esta iniciativa abrió camino a la aparición del nuevo Estándar Global para el Intercambio Automático de Información (CRS) el 21 de julio de 2014.

\subsection{Convención Multilateral sobre Asistencia Administrativa Mutua en Materia Fiscal - CAMMT}

La Convención de Asistencia Administrativa Mutua en Materia Fiscal (en adelante CAMMT) tiene sus orígenes en el acuerdo creado por la OCDE y el Consejo Europeo en 1988

Es un mecanismo de carácter multilateral con el objetivo de fomentar la cooperación internacional a efecto de mejorar la aplicación de las legislaciones tributarias nacionales y optimizar el funcionamiento de los sistemas tributarios correspondientes. Para tal efecto contempla todas las formas posibles de cooperación de carácter administrativo incluyendo la determinación y recaudación de tributos, pasando por el intercambio de información, apoyo en la notificación de documentos, cobro de reembolsos de impuestos extranjeros, auditorías tributarias simultáneas y la participación en auditorías en el extranjero.

En lo que se refiere al intercambio de información, sigue un esquema muy similar al MOCDE, considerando que es un instrumento de la referida organización sigue los lineamientos por ella emitidos; no obstante el gran aporte es la incorporación del intercambio automático en base al CRS. 
Efectivamente, pues en el año 2010 se realizaron modificaciones a la CAAMMT, a fin de alinearla con los estándares internacionales de intercambio de información y transparencia y, de este modo dar una respuesta adecuada al nuevo contexto internacional y ampliar el número de estados participantes.

Sobre este modelo cabe resaltar el numeral 3 del artículo cuarto, que a diferencia de otros convenios prevé que los estados participantes pueden comunicar a sus nacionales o contribuyentes sobre la solicitud de información formulada referida a ellos:

\section{Artículo 4: Provisiones Generales}

3) Cualquier Parte puede, mediante declaración dirigida a uno de los depositarios, indicar que, de conformidad con su legislación interna, sus autoridades podrán informar a sus residentes o nacionales antes de transmitir información relacionada con ellos, de conformidad con los Artículos 5 y $7 .{ }^{20}$.

Adicionalmente, en el preámbulo del convenio se establece la obligación de los estados participantes de respetar los derechos de los contribuyentes en cuanto a no discriminación, doble imposición así como otros intereses legítimos. Adicionalmente, reconoce la primacía de la legislación doméstica, pues señala expresamente que si algo está prohibido o restringido en la legislación nacional, el estado participante deberá anotarlo en el convenio y no podrá aplicar dicha parte del convenio.

Así el 29 de octubre de 2014 se firmó por primera vez el convenio multilateral de acuerdo con lo dispuesto en el artículo 6 de la CAMMT, cuyos primeros intercambios se espera se realicen a mediados de este año. A la fecha son cien los estados que se encuentran comprometidos con este nuevo estándar del intercambio automático. De otro lado, cabe indicar que Perú aún no ha suscrito la CAMMT, por lo que no se encuentra legalmente obligado en el intercambio de información automática; no obstante tener la voluntad política de hacerlo como ya se ha comentado.

\subsection{Intercambio Automático de Información - CRS: Un nuevo estándar}

\footnotetext{
${ }^{20}$ Este convenio no se encuentra traducido oficialmente al español, la traducción encontrada en la página de la OECD es cortesía del Gobierno Mexicano. Recuperado el 7 de marzo de 2017, de http://www.oecd.org
} 
En este afán de lograr mayor transparencia y debido a presiones políticas de movimientos civiles y medios de comunicación que denunciaron los esquemas utilizados por las empresas multinacionales para evitar el pago de impuestos, el 19 de abril de 2013 los jefes de estado participantes del $\mathrm{G} 20^{21}$, así como directores de los bancos centrales, apoyaron y declararon el Intercambio Automático de Información como el nuevo estándar internacional. Esta declaración coincidió con el pronunciamiento de un grupo de mandatarios europeos a favor de un instrumento multilateral para el intercambio de información basado en el modelo FATCA ${ }^{22}$.

Asimismo, se resaltó la importancia de incluir la participación de los países en vías de desarrollo; una cuestión que en nuestra opinión es vital ya que a mayor cantidad de países informantes será mayor el grado de transparencia, sobre la base de los principios de reciprocidad y buena fe que rigen la cooperación internacional.

La OCDE y el G-20 desarrollaron este estándar con el aporte de otras jurisdicciones y en consulta con los sectores financieros. De este modo, el 15 de julio de 2014 el Concejo de la OCDE aprobó el "Estándar para el Intercambio Automático de Información Financiera en Materia Fiscal” o "Common Reporting Standard”, pero más conocido como "CRS", de acuerdo al cual los estados participantes intercambiaran anualmente y de forma automática información obtenida por sus instituciones financieras como balances, intereses, dividendos y ventas de activos financieros, además de cuentas mantenidas por individuos y entidades, incluyendo trusts y fundaciones, exigiéndose así revisar a través de entes pasivos y dar con los individuos que tienen el último control sobre dichos entes.

El estándar es muy similar al Modelo AI $1^{23}$ que muchas jurisdicciones utilizarán para la implementación del FATCA.

La norma requiere que las instituciones financieras reporten información sobre las cuentas en su poder de las personas y entidades no residentes (incluyendo fideicomisos) a su administración tributaria. La administración tributaria transmite de forma segura la información a los países de residencia de los titulares de la cuenta "sobre una base anual".

\footnotetext{
${ }^{21}$ El G20 es un foro de 19 países y la Unión Europea en el que participan jefes de estado, representantes de entidades financieras con el objetivo de discutir temas financieros y de economía global.

${ }^{22}$ OECD. (2016). Standard for Automatic Exchange of Financial Account Information - Common Reporting Standard. París: OECD Publishing.

${ }^{23}$ Que se desarrolla en el Capítulo 2, numeral 3 del presente trabajo.
} 
Figura 2.1. Marco Básico del Common Reporting Standard

\section{CRS: el marco básico}

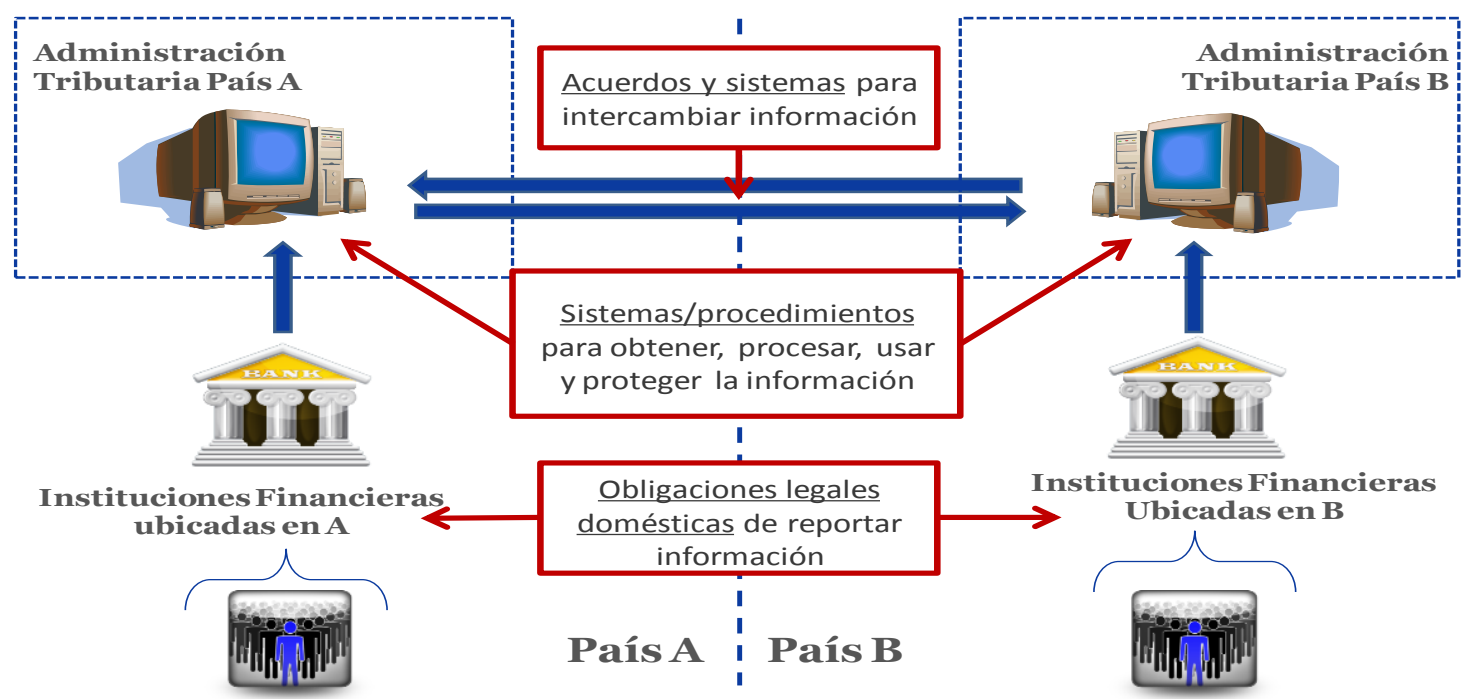

Fuente: Materiales del Seminario sobre intercambio internacional de información para fines fiscales organizado por la OCDE. México. 2013

El estándar detalla la información de las cuentas financieras a ser intercambiada, las instituciones financieras que deben informar, y los diferentes tipos de cuentas y contribuyentes que abarca. A efecto de incluir mayor información, se requiere no solo a los bancos, sino también a otras instituciones tales como las instituciones de custodia, de inversión y ciertas compañías de seguros.

El tipo de información de las cuentas a informar incluye los saldos de las mismas, los intereses, los dividendos, y la venta y reembolso de activos financieros.

Con el fin de garantizar que la información es exacta y completa, la norma también especifica la metodología para la recopilación de información y los procedimientos a seguir por las instituciones financieras. Estos procedimientos se basan en las normas internacionales existentes para la lucha contra el lavado de dinero.

Así también, se establecen requisitos claros que deben ser cumplidos por todas las jurisdicciones que participan en este intercambio tales como la confidencialidad, las medidas de seguridad informática y el uso adecuado de la información.

Es del caso precisar, que el término instituciones financieras no sólo incluye bancos y depositarios, sino también a otras entidades como corredores o agentes y ciertos vehículos de inversión colectiva, así como a determinadas compañías de seguros. 
Adicionalmente, el estándar contiene modelos de acuerdos entre gobiernos y entidades financieras, así como formatos y requisitos para preservar la seguridad de la información, para poner en funcionamiento el intercambio automático y una guía técnica de usuario para asegurar que la información se presenta en un formato estandarizado.

\subsection{EI Plan BEPS}

El 5 de octubre de 2015 la OCDE publicó su informe final del Proyecto OECD/G20 sobre Erosión de la Base Imponible y el Traslado de Beneficios (en adelante Plan BEPS); un ambicioso plan que se inició en julio de 2013, cuyo objetivo principal es prevenir los planeamientos tributarios agresivos que las empresas multinacionales llevan a cabo con la intención de reducir su carga tributaria.

Conforme a su nombre, el Plan BEPS tiene como propósito hacer frente a las estrategias de planificación fiscal agresiva que utilizan las diferencias que existen entre los distintos sistemas tributarios para lograr una significativa reducción de cargas tributarias o, incluso una doble no imposición mediante la transferencia "artificial" de los ingresos a estados de baja o nula imposición; es decir, a lugares ajenos a aquel en donde se llevó a cabo la actividad económica y/o se generó el valor agregado. Así pues, es objetivo del Plan BEPS lograr la alineación entre tributación y actividad económica.

Ahora bien, este problema que implica el uso de más de una jurisdicción, no puede ser resuelto exclusivamente mediante los convenios de doble imposición, pues al ser en la mayoría de los $\operatorname{casos}^{24}$ bilaterales tienen un alcance limitado; de este modo, el proyecto BEPS constituye una plataforma para el desarrollo de una política tributaria internacional.

\subsubsection{La Acción 13 del Plan BEPS - Documentación sobre Precios de Transferencia e Informe País por País}

La Acción 13 está muy ligada con las Acciones 8 - Precios de Transferencia en Intangibles, 9 - Precios de Transferencia Riesgos y Capital y 10 - Precios de

\footnotetext{
${ }^{24}$ Existen experiencias de convenios para evitar la doble imposición de carácter multilateral, como es el suscrito por los países de la Comunidad Andina de Naciones aprobado por la Decisión $\mathrm{N}^{\circ} .578$ de la CAN, denominado Régimen para Evitar la Doble Tributación y Prevenir la Evasión Fiscal (que sustituyó a la Decisión N. ${ }^{\circ} 40$ ), y la Convención Nórdica sobre el impuesto a la Renta y el Capital, en base al MOCDE, suscrita por Finlandia, Islandia, Noruega y Suecia en 1983.
} 
Transferencia en Transacciones de Alto Riesgo, referidas a la debida aplicación del principio de plena competencia y, que así la generación del valor en operaciones transfronterizas entre partes vinculadas se refleje en sus acuerdos y transacciones económicas.

La finalidad de la Acción 13 es reevaluar la documentación que se requiera para sustentar los precios de transferencia, por lo que propone tres niveles de documentación:

a) El master file, como un documento que permitirá a las autoridades tributarias de los países interesados obtener información sobre las operaciones de las empresas multinacionales y sus políticas en materia de precios de transferencia. Este documento deberá ser elaborado en la jurisdicción en donde se encuentre la oficina central del grupo.

b) El local file, este es un archivo que contendrá información en mayor detalle sobre la compañía y sus operaciones en determinada jurisdicción. Este informe incluirá documentación sobre transacciones concretas con entidades vinculadas, el monto y el análisis de determinación de los precios de transferencia y, deberá ser presentado directamente ante las administraciones tributarias de cada país donde se encuentran las subsidiarias.

c) El informe País por País o denominado “Country by Country reporting”, es un informe que será presentado por la multinacional ante la autoridad tributaria donde reside la matriz. Este documento contendrá información sobre los ingresos, beneficios antes de impuestos y los montos de los impuestos pagados y devengados en cada una de las jurisdicciones en las que la multinacional opera, además del número de empleados, capital aportado, beneficios no distribuidos y activos intangibles en cada jurisdicción.

Asimismo, se establece que las jurisdicciones deberán aportar la información en el correspondiente año fiscal y no más de 18 meses después del cierre de dicho año. Cabe resaltar que este informe será compartido entre las jurisdicciones a través de los mecanismos de intercambio automático de información según lo establecido en la CAMMT.

De otro lado, en cuanto a la confidencialidad, las jurisdicciones se comprometen a guardar la confidencialidad y hacer un uso apropiado de la información compartida. No obstante, las jurisdicciones no están impedidas de utilizar la información contenida en el Informe País por País como la base para hacer observaciones a los acuerdos de precios de transferencia de los grupos multinacionales u otros asuntos fiscales como parte de una 
auditoría tributaria. De este modo, en cuanto la autoridad tributaria correspondiente posea suficiente información sobre la situación tributaria de un contribuyente, deberá actuar de manera rápida para verificar que lo declarado por el contribuyente no ofrece inconsistencias.

Como se puede apreciar este es un sistema informativo altamente integrado, permitiendo a la administración tributaria de un país notificar inmediatamente a la autoridad tributaria del otro país involucrado sobre el incumplimiento de algún contribuyente, así como las acciones adoptadas al respecto.

Ahora bien, debe anotarse que las medidas propuestas por la Acción 13 no solo son fundamentales en la implementación de las Acciones 8 a 10, sino también de otras acciones como la 2, 3 y 4 (uso de mecanismos híbridos, transparencia fiscal y deducción de intereses).

En resumen, tenemos el siguiente cuadro con las características de los principales instrumentos internacionales analizados:

Tabla 2.1.Convenios Internacionales y las modalidades de Intercambio de información

\begin{tabular}{|c|c|c|c|c|}
\hline CONVENIOS & AUTOMÁTICO & A SOLICITUD & ESPONTANEO & CARACTERÍSTICAS \\
\hline MOCDE & SI & SI & SI & $\begin{array}{l}\text { 1. Información previsiblemente } \\
\text { relevante. } \\
\text { 2. Prohibición solicitudes de } \\
\text { información generales (Fishing } \\
\text { Expeditions) } \\
\text { 3. Permite el uso de } \\
\text { información por otras autoridades. }\end{array}$ \\
\hline MONU & SI & SI & SI & $\begin{array}{l}\text { 1. Texto similar Art. } 26 \text { MOCDE. } \\
\text { 2. Permite el uso de información por } \\
\text { otra autoridades. }\end{array}$ \\
\hline FATCA & SI & NO & NO & $\begin{array}{l}\text { 1. Amplio alcance de información } \\
\text { financiera. } \\
\text { 2. Carácter unilateral e impositivo. }\end{array}$ \\
\hline CAMMT & SI & SI & SI & $\begin{array}{l}\text { 1. Carácter multilateral } \\
\text { 2. Mayor protección a los derechos } \\
\text { de los contribuyentes. }\end{array}$ \\
\hline
\end{tabular}


Fuente: Elaboración propia

\section{Capítulo III: LÍMITES AL INTERCAMBIO DE INFORMACIÓN}

\subsection{Derechos del Contribuyente: Desarrollo y estado actual}

A diferencia de los derechos humanos, los derechos del contribuyente han sido materia de discusión recién a partir del último cuarto del siglo XX; aunque no se puede negar el profundo efecto que los primeros tuvieron con relación al reconocimiento y desarrollo de los derechos del contribuyente. 
Como lo señala Brzeziski (2009), la International Fiscal Association (IFA) en un seminario realizado en 1987, elaboró un folleto que contiene uno de los primeros borradores sobre el tema. Posteriormente, durante la década de los 90's diversas administraciones tributarias con el fin de incentivar el cumplimiento voluntario de sus contribuyentes tomaron como referencia las pautas contenidas en el reporte "Derechos y Obligaciones de los Contribuyentes un estudio sobre la situación legal en los países de la OCDE" emitido por la OCDE (1990).

En el citado reporte se enfatizaron los principios que debían regir la relación entre administración tributaria y contribuyentes, y se adoptó un nuevo enfoque con respecto a los derechos de los contribuyentes. Posteriormente la OCDE emitió nuevos reportes como el "Principles of Good Tax Administration - Practice Note en el 2001" y el “Taxpayers' Rights and Obligations" en el 2003; cuyo enfoque subyacente era incrementar el nivel de cumplimiento tributario a través de un marco de derechos más amplio.

No obstante, en los últimos años la confianza entre las autoridades y los contribuyentes ha ido decreciendo, siendo la principal causa el uso de los denominados métodos de planificación fiscal agresiva y, del otro lado las filtraciones producidas de información de carácter personal que genera que los ciudadanos sean mucho más reticentes a la entrega de la misma por el temor de que su información pueda ser utilizada con fines distintos a los impositivos y, que puedan incluso poner en riesgo su seguridad. Al respecto, queremos dejar en claro que la planificación fiscal no es por sí misma ilegal, en tanto se estructure en función y dentro de los parámetros de la legislación, por lo que no debe ser confundida con la evasión fiscal. Una consideración diferente merece la planificación fiscal agresiva, pues esta opera en los bordes del marco legal, contradiciendo el propósito de las leyes y generando millonarias pérdidas a los estados, siendo incluso su efecto mayor en los países en vías de desarrollo (Osorio Manyari, 2016).

En este contexto, se presenta un dilema para las autoridades tributarias a nivel mundial, a efecto de lograr una relación armónica y equilibrada con sus administrados: 
Figura 3.1. Protección de la base tributaria vs. Derechos de los contribuyentes:
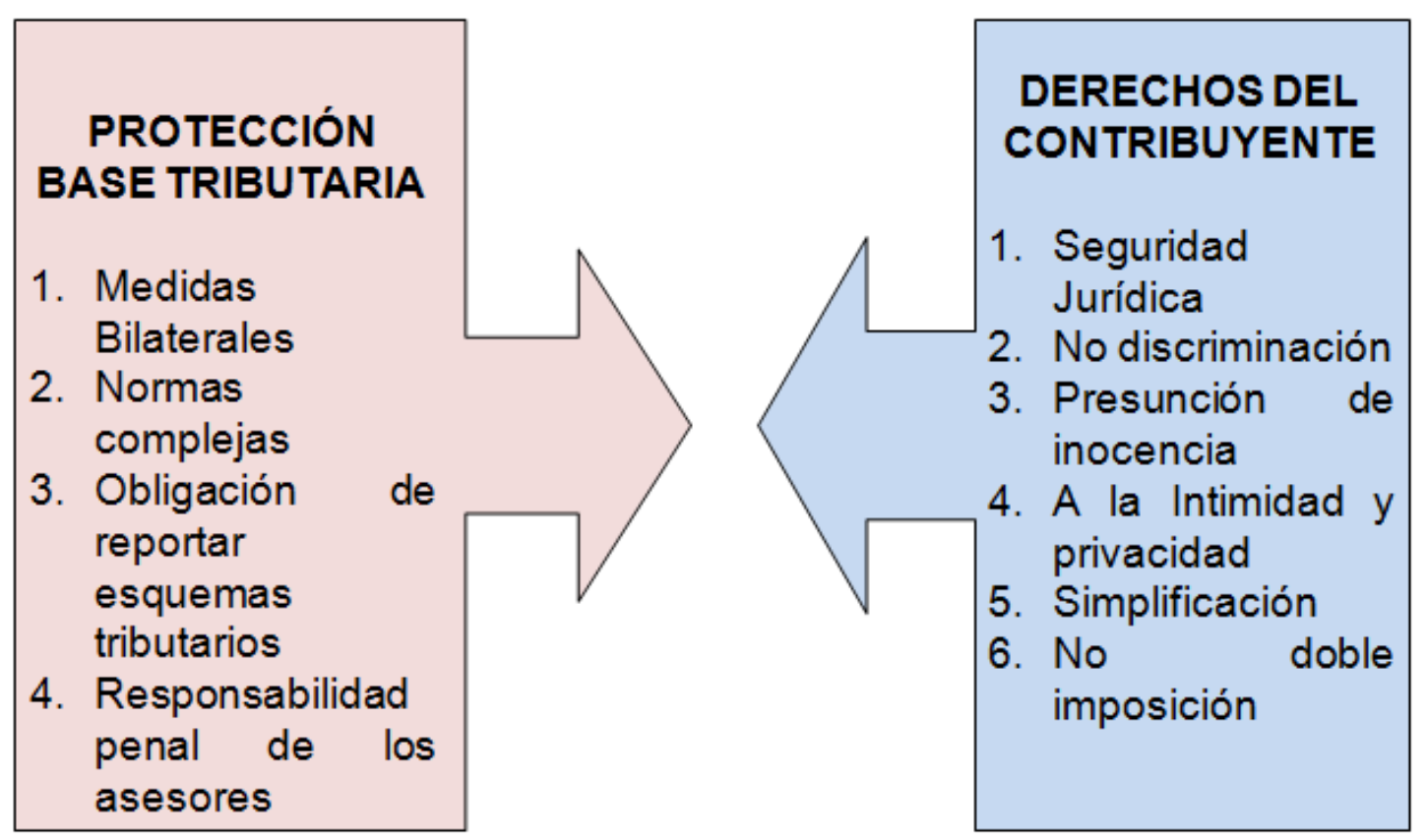

Fuente: Elaboración propia

Cabe indicar que si bien en los nuevos convenios se contemplan limitaciones al intercambio de información, estas se encuentran referidas a una protección indirecta, dejando la protección directa en el campo de la legislación interna de cada uno de los Estados.

De otro lado, es insoslayable el tener en cuenta que no se puede equiparar la posición de los contribuyentes con la de la administración tributaria, pues en la relación que se establece entre ellos esta última suele tener una posición superior.

Este desequilibrio se evidencia al revisar la operatividad del intercambio de información automático, en el que el contribuyente no es consultado sobre la posibilidad de que su información financiera sea compartida con otros Estados y, que incluso dicha información pueda ser utilizada con propósitos distintos a los tributarios en tanto así esté previsto en los instrumentos jurídicos al amparo de los cuales se realiza el intercambio.

Frente a esta situación, ciertas organizaciones internacionales realizaron foros para discutir y proponer la adopción de un código para los contribuyentes, en el que se integren y se reconozcan los derechos de estos sujetos en estos nuevos mecanismos de control tributario. Así, la "Asia-Oceania Tax Consultants Association”, la "Confédération Fiscale Européenne" y la "Society of Trust and Estate Practitioners" fueron las primeras asociaciones que iniciaron este movimiento y efectuaron una encuesta entre 37 países 
contando con la participación de la OCDE, el Comité de Asuntos Fiscales de la ONU, el Banco Mundial, el Fondo Monetario Internacional entre otros. En el reporte respectivo se indicó que:

i) La sola aplicación de sanciones no es suficiente para alcanzar mejores niveles de cumplimiento tributario, pues un sistema percibido como justo tiene mejores resultados; $\mathrm{y}$,

ii) Si se desea encajar el sistema tributario en el siglo XXI se debe aceptar que la transparencia, claridad y simplicidad sólo son posibles en un contexto en el que los contribuyentes son tratados con igualdad (Confédération Fiscale Européenne, Taxpayer Charter Press Release, 2015).

Sin embargo, pese al entusiasmo inicialmente mostrado, el proyecto aún no ha llegado a concretarse; esto es, no se ha emitido ni adoptado ninguna norma internacional que recoja de manera efectiva dichos postulados; por lo que muchos contribuyentes se vienen organizando en asociaciones internacionales para promover y proteger sus derechos, así puede citarse a la "Asociación Mundial de Contribuyentes" que comprende asociaciones de distintos países como los Estados Unidos, Australia, Ucrania, España, India, Japón, etc. ${ }^{25}$. En nuestra opinión, esta debe ser una advertencia para que los órganos estatales e interestatales realicen acciones concretas que evidencien su compromiso con estas declaraciones.

\subsubsection{Principios del sistema tributario}

En el contexto actual, en el que la tecnología juega un rol importante tanto para las administraciones tributarias como para los contribuyentes, surgen interrogantes respecto a cuál es el marco legal para lograr un sistema tributario legítimo y efectivo, o cómo se deben enfrentar las áreas grises existentes en las situaciones en que ley, regulación y práctica convergen. Al respecto, el profesor Bentley (2015) indica que para responder estas interrogantes lo más fácil sería recurrir directamente a algún documento donde se regulen los derechos de los contribuyentes; sin embargo, a la luz de la situación mundial antes señalada, considera que esto no es suficiente y, con lo cual concordamos, es mucho más útil revisar los principios jurídicos que se han ido desarrollando durante siglos y que

${ }^{25}$ World Taxpayers Association. Ver: http://worldtaxpayers.org/ 
dan las bases para el diseño de un sistema tributario, así como para el marco de los derechos de los contribuyentes.

Ahora bien, no se puede desconocer que los principios no son estáticos y evolucionan conforme pasa el tiempo y según el contexto; no obstante se caracterizan por su generalidad, ya que de regular de manera específica perderían su aplicabilidad. Debido a su generalidad, suelen competir entre sí, siendo tarea del juez, como interpretador por excelencia de las normas, encontrar el equilibrio entre los mismos. Sin embargo, esto genera que en el diseño de los sistemas tributarios en base a consideraciones de política fiscal prevalezcan algunos sobre otros; por ejemplo, muchas veces se sacrifique el principio de equidad vertical por otros principios ${ }^{26}$. En tal sentido a continuación detallamos como estos principios encuentran su expresión en el ámbito tributario:

\section{A. Equidad y Justicia}

a) El diseño de un sistema tributario debe tener en cuenta la igualdad horizontal y vertical.

b) Es importante que la sociedad perciba al sistema como justo.

c) Casos similares -contribuyentes en situaciones similares llevando a cabo operaciones similares - deben estar sujetos a niveles similares de tributación.

d) De igual manera a nivel internacional la equidad entre naciones debe ser considerada como un principio.

\section{B. Certeza y Simplicidad}

a) Las normas tributarias no deben ser arbitrarias.

b) Las normas tributarias deben ser claras y simples, de fácil comprensión en la medida que la complejidad de la materia tributaria lo permita. De esta manera, los contribuyentes pueden prever las consecuencias tributarias de sus operaciones, incluyendo cuándo, dónde y cómo deberán satisfacer la obligación.

c) Debe existir transparencia y participación en el diseño e implementación de las normas tributarias.

\section{Eficiencia}

\footnotetext{
${ }^{26}$ En nuestra teoría jurídica, esto vendría a ser los denominados conflictos de derechos.
} 
Los costos de cumplimiento y administración deben ser los mínimos y, el pago del impuesto debe ser lo más fácil posible.

\section{Neutralidad}

a) El sistema tributario no debe impedir o reducir la capacidad de la producción de la economía y, mucho menos generar distorsiones.

b) Las decisiones empresariales deben ser motivadas por razones económicas más que por consideraciones de carácter impositivo. Tanto en la importación como en la exportación de capital ${ }^{27}$.

\section{E. Efectividad}

a) El sistema debe estar diseñado para que el pago del impuesto se haga por el monto correcto en el momento correcto, evitando la doble imposición o la doble no imposición, tanto a nivel doméstico como internacional.

b) El sistema debe ser flexible y dinámico de modo que se adapte a los desarrollos tecnológicos y comerciales.

c) Los probabilidad de incumplimiento tributario (activo/pasivo) debe ser minimizada con medidas en proporción al riesgo presente.

\subsubsection{Clasificación de los derechos del contribuyente}

Asimismo, de acuerdo con Bentley (2015), los derechos de los contribuyentes se pueden dividir entre derechos legales y administrativos $\mathrm{y}$, estos a su vez pueden subdividirse en primarios y secundarios. Los derechos legales primarios, son los fundamentos que subyacen al sistema tributario y que constituyen límites a los poderes legislativo y ejecutivo (legalidad, irretroactividad por ejemplo).

Mientras que los legales secundarios se refieren a la operación especifica de la ley, como son el acceso a la justicia, derecho a la confidencialidad de la información, motivación de resoluciones, entre otros. Asimismo, son derechos administrativos primarios, aquellos derechos legales secundarios que se encuentran regulados de forma administrativa. Mientras que derechos administrativos secundarios aquellos que no pueden ser legislados eficientemente pero que se reconocen en procedimientos

\footnotetext{
${ }^{27}$ En cuanto a inversiones en el exterior e inversiones extranjeras, se puede decir que un país como los EEUU -que tiene varios inversionistas en el exterior- prefiere aplicar el principio de neutralidad a la exportación de capitales; mientras que un país con economía pequeña, como Perú, preferiría aplicar el principio de neutralidad a la importación de capitales. Para un mayor análisis ver: Kemmeren, E.C.C.M., "Source of Income in Globalizing Economies: Overview of the Issues and a Plea for an Origin-Based Approach".
} 
particulares, tal es el caso por ejemplo del derecho a recibir asistencia a tiempo de la administración tributaria.

Para efectos del presente trabajo solo desarrollaremos los derechos legales primarios, toda vez que estos son los que proveen el soporte para las demás normas y regulaciones, y cualquier combinación de los mismos permitirá verificar si determinada disposición, práctica o acto se encuentra alineado con los principios fundamentales antes mencionados:

a) Los tributos deben ser impuestos por ley o norma con dicho rango (Reserva de ley)

b) Las normas tributarias deben ser publicadas (Transparencia)

c) Las normas tributarias no deben ser retroactivas (Certeza, Seguridad jurídica)

d) Las normas tributarias deben ser comprensibles (Certeza, Seguridad jurídica y Simplicidad)

e) Las normas tributarias no deben ser contradictorias (Certeza, Seguridad jurídica)

f) El contribuyente debe estar en la capacidad de obedecer la ley (Equidad, Efectividad y Eficiencia)

g) Los cambios frecuentes no deben minar el sistema tributario (Certeza, Seguridad jurídica)

h) Las normas tributarias deben de ser cumplidas (Justicia, Transparencia, Certeza, Seguridad jurídica, Transparencia y Efectividad)

i) Los contribuyentes no deben pagar más de lo que les corresponde (Justicia, Efectividad y Certeza)

j) Las normas tributarias no deben generar doble tributación (Justicia y Efectividad)

k) Las normas tributarias no deben ser discriminatorias y debe primar la igualdad ante la ley (Justicia y Equidad)

1) Las normas tributarias deben satisfacer el principio de proporcionalidad (Justicia, Equidad y Efectividad)

m) Los contribuyentes deben tener derecho a la privacidad (Justicia)

n) Los contribuyentes deben tener derecho a la confidencialidad y a la privacidad (Justicia)

o) Los contribuyentes deben tener derecho al acceso a las cortes (Justicia), según las siguientes características: 
i. Tribunales independientes e imparciales;

ii. Audiencia pública;

iii. Juicio justo;

iv. Derecho a guardar silencio;

v. El derecho a ser representado;

vi. Juicio dentro de un plazo razonable.

\subsubsection{Test para verificar la viabilidad de las prácticas del Estado}

Conforme a los principios y parámetros analizados en los apartados anteriores, la legislación sobre Intercambio de Información responde en mayor magnitud a los intereses del Estado y, en consecuencia presta menor atención a los derechos del contribuyente. Ahora bien, sin perjuicio de la clasificación realizada por Bentley sobre los derechos del contribuyente y la Carta de Derechos del Contribuyente desarrollada por el profesor Cockfield (2010), atendiendo a los aspectos que debe tenerse en cuenta para determinar la capacidad de un estado para llevar a cabo un proceso de intercambio de información de manera adecuada y equilibrada respecto de los intereses de la administración tributaria y de los administrados, se puede aplicar una especie de test simplificado que evalúe la viabilidad de las prácticas del Estado con respecto a los derechos del contribuyente. Así este test toma en consideración cuatro aspectos:

\section{i) La buena administración}

Para la evaluación de este aspecto se pone atención en el respeto a la ley y, en general a la normativa vigente, pues no debemos olvidar que la actuación de la administración debe ejercerse dentro del marco de la legislación correspondiente y conforme a las facultades y competencias que le han sido conferidas. Para tal efecto, debemos tener presente que en un Estado de derecho la ley es formulada conforme al procedimiento constitucional pertinente y que para su validez se exige, entre otros, su publicidad.

De la misma manera se aprecia el que una buena administración debe asegurar a sus administrados el acceso a la información, el desarrollo de facilidades para el cumplimiento de las obligaciones a su cargo, así como herramientas que permitan la cooperación entre los estados y, sobretodo, la colaboración entre estado y contribuyente. 
Una manera de verificar este criterio es la apropiada implementación del intercambio automático de información, considerado como una buena práctica administrativa, en tanto se encuentre sustentada en los instrumentos jurídicos pertinentes $\mathrm{y}$, siguiendo los procedimientos establecidos previamente; así como utilizando los canales habilitados legalmente, dado que estos procedimientos de intercambio de acuerdo al reciente estándar internacional, se efectivizarán mediante sistemas electrónicos altamente desarrollados, con lo cual se garantiza la transparencia y, por ende la ausencia de discrecionalidad en el proceso.

\section{ii) Confidencialidad}

Un elemento importante en la relación administración-contribuyente es la confianza, referida - entre otros aspectos ${ }^{28}$ - al carácter reservado del manejo y conservación de la información que le proporciona a la administración o que esta obtiene en el ejercicio de sus facultades y, al fin para el cual será utilizada; es decir para la correcta determinación de sus obligaciones tributarias.

Esta exigencia, con mayor razón se traslada a nivel internacional, motivo por el cual los convenios se efectúan en base al principio de la confidencialidad. En el caso del intercambio de información, solo las autoridades competentes podrán autorizar dicho intercambio y velarán por el mantenimiento reservado de la información que obtengan a través de este procedimiento. Así por ejemplo, los estados involucrados en el intercambio automático de información, a través de sus administraciones deberán prever los mecanismos para asegurar incluso la protección contra hackers o que sujetos no autorizados tengan acceso a la información materia de intercambio, garantizando así la confidencialidad de la misma.

Este criterio también implica que los tratados no pueden violar ninguna ley doméstica de protección a la privacidad o confidencialidad respecto de algún tipo de información.

\section{iii)Derecho a la Información}

En la práctica los contribuyentes no suelen ser informados que se está realizando o se ha realizado un intercambio de información respecto a él, dado

\footnotetext{
${ }^{28}$ Como por ejemplo en la legitimidad del accionar de la administración en tanto su sujeción a la ley, como se viera en el acápite anterior.
} 
a que pocos de los instrumentos existentes prevé dicha posibilidad. A nivel internacional, como hemos visto, solo la CAMMT explícitamente considera la posibilidad de que el contribuyente sea informado sobre el intercambio de su información, dejando la decisión final en la ley interna. Como señala Calderón (2000) el resultado es que el contribuyente ignora quien posee información sobre él y para qué fin la información será utilizada.

\section{iv) Derecho de Contradicción}

Partiendo de la situación en que el contribuyente no está informado sobre los procedimientos de intercambios de información realizados o por realizarse, es claro que no se encuentra en aptitud de oponerse a que el mismo se efectúe. Dado que ningún instrumento incluye explícitamente el derecho de contradicción por parte del contribuyente $\mathrm{y}$, por tanto hay una ausencia respecto del recurso legal específico para ejercer este derecho; se puede concluir que este aspecto constituye un vacío legal a fin de una efectiva protección de los derechos del contribuyente.

En la práctica el resultado es que el contribuyente solo se encontrará en posibilidad de contradecir el procedimiento cuando este ha concluido; es decir con posterioridad al mismo, pero nunca estará en condiciones de oponerse a la realización del intercambio y, mucho menos contradecir el sistema en sí mismo, con lo cual queda abierta la eventualidad de que se cometa algún error, que incluso pueda causar perjuicio al contribuyente, como podría ser una errónea calificación de información que no pueda ser materia de intercambio por tratarse de información de carácter personal privado o hasta casos de homonimia o confusión de identidad.

A continuación se presenta un cuadro con el resumen de la aplicación del test a los principales modelos de convenios de Intercambio de Información:

Tabla 3.1. Principales modelos de convenios de intercambio de información y los derechos de los contribuyentes

\begin{tabular}{|l|c|c|c|c|c|}
\hline \multicolumn{1}{|c|}{ CRITERIO } & MOCDE & MONU & FATCA & CAMMT & CRS \\
\hline Buena administración & SI & SI & SI & SI & SI \\
\hline Confidencialidad & SI & SI & SI & SI & SI \\
\hline Derecho a ser informado & NO & NO & NO & SI* & NO \\
\hline
\end{tabular}




\begin{tabular}{|l|c|c|c|c|c|}
\hline $\begin{array}{l}\text { Derecho de } \\
\text { contradicción }\end{array}$ & NO & NO & NO & NO & NO \\
\hline
\end{tabular}

*Se contempla como una posibilidad, más no como un mandato

Fuente: Elaboración propia

\section{CAPÍTULO IV: INTERCAMBIO DE INFORMACIÓN EN EL PERÚ}

\subsection{El Perú en el contexto global}

Perú es un país en vías de desarrollo calificado como de ingreso mediano, cuya actividad económica más importante es la exportación de materia prima principalmente metales y 
minerales. Considerado el segundo y tercer productor más importante de plata y cobre a nivel mundial, respectivamente y el primer productor de oro en Latinoamérica.

La economía peruana ha mejorado notablemente en las dos últimas décadas, actualmente se encuentra entre los países latinoamericanos con mayor crecimiento del producto bruto interno y menor grado de inflación. Así en los últimos años nuestro país experimentó un crecimiento muy importante que se caracterizó adicionalmente por una mayor apertura de la economía: Los contribuyentes domiciliados por necesidades de mercado empezaron procesos de internacionalización, empresas extranjeras por su parte empezaron a operar más con el país a través de Establecimientos Permanentes, mediante la adquisición de empresas locales o mediante otros mecanismos, como se puede apreciar en el gráfico siguiente:

\section{Figura 4.1. Inversiones Peruanas en el extranjero}

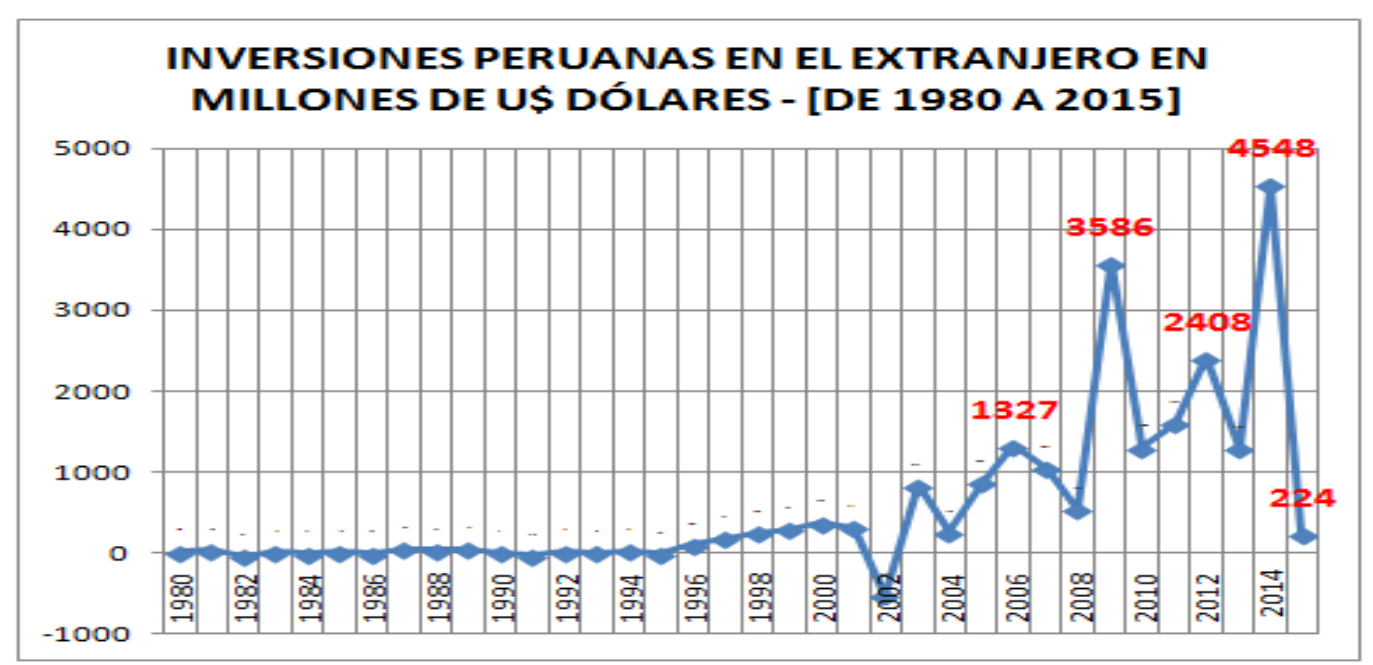

Fuente: Estadísticas BCRP / Cuadros trimestrales / 18 - Cuenta Financiera del Sector Privado

Es innegable la gran importancia que la inversión extranjera directa tiene en la economía del país y que la política económica y fiscal peruana tienen como finalidad la atracción de capitales.

En cuanto a la recaudación, cabe indicar que parte importante del ingreso público proviene de la recaudación de impuestos. Esta situación originó que el mercado peruano se volviera más sofisticado, y empiecen a aparecer una gran variedad de contratos y operaciones cuyo tratamiento ponía en riesgo la base tributaria peruana, debido a que ante la falta de un control de riesgos estas operaciones podrían devenir en evasión o elusión. 
Esta situación no es solo observable en el país, pues es una constante en muchos países del mundo.

Así, en los últimos años la economía peruana y, por ende la recaudación han venido decayendo, ello producto de la reducción experimentada en las exportaciones y la caída de los precios de las materias primas; sin perjuicio del alto nivel de evasión tributaria del que padece el país.

Frente a esta realidad, la Superintendencia Nacional de Aduanas y de Administración Tributaria (SUNAT) ha manifestado su preocupación por el descenso de la recaudación; indicando además que otra de las causas en la perdida de la recaudación es el planeamiento tributario agresivo llevado a cabo por las empresas multinacionales, las cuales, irónicamente, suelen ser los principales contribuyentes del país, como se puede apreciar en el siguiente gráfico:

Figura 4.2. Participación en la Recaudación - Contribuyentes

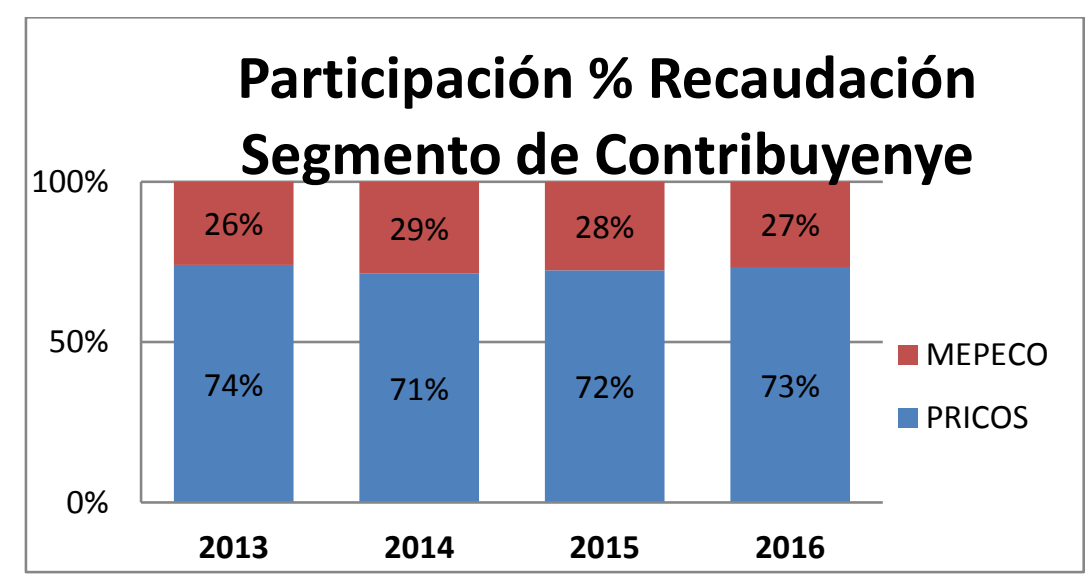

Fuente: Datos de la Intendencia Nacional de Estudios Tributarios y Estadística .Elaboración propia

$\mathrm{Al}$ respecto, cabe indicar que entre las preocupaciones manifestadas por los países en vías de desarrollo en cuanto a las prácticas BEPS, se encuentra la dificultad para la obtención y/o falta de información respecto de los contribuyentes, lo que trae problemas en la determinación de los impuestos así como en la aplicación de las normas sobre precios de transferencia conforme lo señala Carmel (2015).

\subsection{Los Tratados suscritos por el Perú y el intercambio de información}

A la fecha el intercambio de información en nuestro país se encuentra en un estado incipiente y bastante restringido, pues a diferencia de otros estados de la región 
latinoamericana, el Perú cuenta con una red de tratados limitada, consistente sólo en ocho tratados para evitar la doble imposición ${ }^{29}$ que contienen una cláusula referida al intercambio de información: uno de carácter multilateral, que es la Decisión N . $^{\circ} 578$ de la Comunidad Andina (CAN) que comprende a Colombia, Ecuador, Perú y Bolivia, y siete (7) bilaterales suscritos con Chile, Canadá, Brasil, México, Corea del Sur, Portugal y Suiza. Adicionalmente tiene tres tratados específicos sobre Intercambio de Información con Estados Unidos, en la modalidad de un acuerdo intergubernamental, aprobado por el Decreto Ley N. ${ }^{\circ} 25665$ el 18 de agosto de 1992,con Argentina a nivel de Administraciones Tributarias para la cooperación técnica e intercambio de información tributaria y aduanera y, con Ecuador referido a Cooperación y asistencia mutua en materia tributaria, ratificado mediante Decreto Supremo N. ${ }^{\circ}$ 077-2002-RE y en vigencia a partir del 7 de enero de 2003.

Las modalidades de intercambio de información consideradas en los instrumentos antes señalados se pueden apreciar en el siguiente cuadro, en el que a nivel de Acuerdos de Intercambio de Información de carácter específico se ha considerado como referencia al suscrito con los Estados Unidos, dado que es el más amplio y el único que a la fecha se estaría utilizando de alguna manera en forma habitual aunque no en su integridad, pues solo se realiza el intercambio en la modalidad de Intercambio a requerimiento:

Tabla 4.1. Modalidades de intercambio en los convenios celebrados por el Perú

\begin{tabular}{|c|l|c|c|}
\hline $\mathbf{N}^{\circ}$ & $\begin{array}{c}\text { MODALIDAD DE } \\
\text { INTERCAMBIO }\end{array}$ & $\begin{array}{c}\text { CDI SUSCRITOS POR EL } \\
\text { PERÚ }\end{array}$ & $\begin{array}{c}\text { AII* CON } \\
\text { EEUU }\end{array}$ \\
\hline $\mathbf{1}$ & A REQUERIMIENTO & SI & SI \\
\hline $\mathbf{2}$ & AUTOMÁTICO & NO & SI \\
\hline $\mathbf{3}$ & ESPONTÁNEO & NO & SI \\
\hline
\end{tabular}

* Acuerdo de Intercambio de Información

Fuente: Elaboración propia

Si bien, conforme a lo dispuesto por el Decreto Ley N. ${ }^{\circ} 25883$, para efectos de la aplicación de los CDI la Autoridad Competentes es el Ministro de Economía y Finanzas; no obstante, a fin de agilizar los procesos de intercambio de información en el marco de los referidos convenios y, atendiendo a que la información se encuentra en poder de la

${ }^{29}$ Aunque se encuentran en etapa de negociación convenios para evitar la doble imposición con Italia, Qatar, Singapur, Reino Unido, Francia, HolandaTailandia, Emiratos Arabes, Singapur y Kuwait. 
administración tributaria, mediante Resolución Ministerial N. ${ }^{\circ}$ 586-2008-EF/10se ha designado al Superintendente Nacional de Aduanas y Administración Tributaria como representante autorizado de la Autoridad Competente en la referida materia.

Los contenidos de los convenios con Chile, Canadá, Brasil, México, Corea del Sur, Portugal y Suiza al haber sido suscritos en base al artículo 26 del MOCDE, cuyo detalle se puede apreciar en el Anexo I, resultan bastante similares; sus diferencias se dan en función a la fecha de su suscripción y, por ende, a la versión del MOCDE que utilizaron. Así los tres primeros lo hicieron en base a la versión vigente en el $2003^{30}$, mientras que los cuatro restantes, al ser más recientes utilizaron la versión del 2010³; sin embargo ninguno de ellos contempla la posibilidad del intercambio de información automático, dado que es recién en la versión del 2014 en la que se introduce esta modalidad.

En consecuencia, tenemos que, respecto a la información a ser materia de intercambio los suscritos bajo el MOCDE 2003 aluden a aquella que resulte "necesaria", en tanto que los demás se refieren a la "previsiblemente pertinente" 32 , siendo el CDI con Brasil en el numeral 4 del artículo $25^{\circ}$ que de manera expresa detalla la amplitud de lo que se considera como información, pues señala "declaraciones y testigos y de copias autenticadas de documentos originales inéditos (incluidos libros, informes, declaraciones, registros contables y anotaciones) ".

No obstante, en lo que respecta a la materia sobre la cual debe estar relacionada la información, se presenta un amplio espectro de opciones que va desde la posición más restrictiva adoptada en los convenios suscritos con Canadá y Portugal, que solo la permiten en tanto se encuentre referida a los impuestos comprendidos en el CDI; pasando por la de Chile, en el que además de los impuestos antes referidos se considera al impuesto al valor agregado; para llegar finalmente a la más amplia que recoge la tendencia mundial, contenida en los convenios suscritos con Brasil, México, Corea del Sur y Suiza. En el caso de Brasil atendiendo a su organización política de república federal solo se alude a la información referida a los "impuestos del Gobierno Central", por lo que solo se encuentran comprendidos los impuestos federales y en el caso del Perú los impuestos que constituyen ingresos del Tesoro Público; en los tres restantes se indica que la información podrá estar relacionada a "cualquier impuesto", con lo cual se cuenta

\footnotetext{
${ }^{30}$ En adelante "MOCDE 2003".

${ }^{31}$ En adelante "MOCDE 2010".

${ }^{32}$ De los cuales, solamente el CDI con México utiliza la formula convencional de "relevante".
} 
con un ámbito bastante extenso que responde claramente al objetivo de lucha contra la evasión fiscal.

En todos los convenios, aunque con algunas variantes en la forma, se contempla el compromiso de obtener la información que se solicite aún cuando esta pueda no representar algún interés para el estado requerido; sin embargo en el CDI con Brasil se consigna expresamente que para tal efecto se deberá observar "las limitaciones constitucionales y legales y la reciprocidad"33.

Así, en cuanto a los límites al intercambio de información ${ }^{34}$, de manera uniforme se consideran los supuestos de que la obtención de la información implique la adopción de medidas administrativas que contravengan la legislación o práctica administrativa de cualquiera de los estado contratantes, así como que esta no pueda ser obtenida de conformidad con la legislación o práctica administrativa normal.

De igual manera, se considera como un impedimento la posibilidad de contravenir el orden público a efecto de ejecutar el intercambio y, atendiendo al carácter confidencial o reservada que pueda ostentar la información. Con algunos matices, también existe coincidencia en señalar que no se podrá intercambiar aquella información que vulnere los secretos comerciales, mercantiles ${ }^{35}$, empresariales ${ }^{40}$, profesionales y procedimientos comerciales.

Sin embargo, la imposibilidad de oponer el secreto bancario o la reserva fiscal como impedimentos para realizar el intercambio de información, se encuentra considerada solo en los convenios celebrados en base al MOCDE 2010, en tanto que es el modelo del 2005 el que la incorporós6; no obstante en el convenio suscrito con Brasil se señala expresamente la posibilidad de la obtención y entrega de información que se encuentre en poder de las instituciones financieras, los mandatarios o personas que actúan como representantes, agentes o fiduciarios, aunque para ello se debe observar el procedimiento correspondiente para tal efecto, en base a lo también estipulado en el mismo y que fuera comentado en párrafos precedentes.

Ahora bien, no obstante que a partir del MOCDE 2010 se admite la posibilidad de que la información obtenida adicionalmente pueda ser destinada a fines diferentes a los tributarios, en tanto la autoridad competente del estado que la proporciona lo autorice, de

\footnotetext{
${ }^{33}$ Numeral3 del artículo $25^{\circ}$ del CDI con Brasil.

${ }^{34}$ Los mismos que los considerados en los numerales del 3 al 5 del artículo $26^{\circ}$ del MOCDE y en el artículo $7^{\circ}$ del Modelo de Acuerdo de Intercambio de Información de la OCDE.

${ }^{35}$ CDIs: México, Corea del Sur, Suiza y Portugal.

${ }^{36}$ En el numeral 5 de la cláusula 26 del MOCDE.
} 
los convenios suscritos por el Perú bajo dicho modelo solo el de Corea del Sur no contempla esa alternativa.

En los CDI se prevé el carácter de secreta que tiene la información obtenida en virtud a un intercambio de información, es decir confidencial, de la misma manera que la información conseguida en virtud a sus disposiciones de derecho interno, como es el caso de la reserva tributaria dispuesta en el artículo 85 del CT y que se desarrollará más adelante.

\subsection{La normativa interna}

Como se indicara al inicio del presente trabajo, el Perú ha manifestado su intención de incorporarse plenamente a la OCDE en el 2021, razón por la cual viene desarrollando una serie de acciones a fin de adoptar los estándares internacionales que se requieren para ello, como son los vinculados a la implementación efectiva del intercambio de información en todas sus modalidades.

Las bases de los estándares antes mencionados se circunscriben a la disponibilidad de información fiscalmente relevante; es decir contar o tener la posibilidad de acceder a la información que se requiera y, estar en capacidad, tanto legal como practica, de poder intercambiarla a través de todas las modalidades, resguardando siempre los derechos de los contribuyentes y el carácter confidencial de la misma; motivos por los cuales resultaba necesario adecuar nuestra normatividad.

En tal sentido, mediante la Ley N. ${ }^{\circ} 30506^{37}$, el poder legislativo delegó en el Poder Ejecutivo la facultad para que legisle, entre otros, en todo lo relacionado a la adecuación de la legislación nacional "a los estándares y recomendaciones internacionales emitidos por la Organización para la Cooperación y el Desarrollo Económicos (OCDE) sobre el intercambio de información para fines tributarios, fiscalidad internacional, erosión de bases imponibles, precios de transferencia y combate contra la elusión tributaria”

De este modo, mediante los Decretos Legislativos Nros. 1313 y 1315, vigentes a partir del primero de enero del presente año, se modificó la Ley N. ${ }^{\circ} 26702$ - Ley General del Sistema Financiero (en adelante LGSF), y el Código Tributario, respectivamente, con la finalidad de incluir regulaciones que permitan efectivizar el Intercambio de Información. Es así que se adoptan provisiones especiales para las instituciones del Sistema Financiero respecto a la información que debe suministrar a la SUNAT, y se

\footnotetext{
${ }^{37}$ Publicada el 9.10.16.
} 
amplían las competencias del ente administrador de tributos para realizar las actuaciones y procedimientos necesarios para llevar a cabo la Asistencia Administrativa Mutua en Materia Tributaria (en adelante AAMMT) en la línea de lo contemplado en la CAMMT, una de cuyas formas es el intercambio de información.

\subsubsection{La AAMMT}

De acuerdo con el nuevo texto de la Norma II del Título Preliminar del CT se debe definir a la AAMMT según lo establecido en los convenios internacionales, tanto aquellos que se celebren de acuerdo al procedimiento previsto en el artículo $55^{\circ}$ de la Constitución Política del Perú como a las Decisiones de la Comisión de la Comunidad Andina. Las modificaciones dispuestas por los citados decretos, con énfasis en la materia que nos ocupa, se pueden resumir en las siguientes:

\section{A) Facultades y competencias de la SUNAT en el marco de la AAMMT}

a) SUNAT presta y solicita AAMMT según lo establecido en los convenios internacionales, aun si carece de interés fiscal para sus propios fines.

b) Formas de AAMMT:

i. Intercambio de información tributaria.

ii. Asistencia en el cobro de deudas.

iii. Notificación de documentos.

c) Para efecto del intercambio de información se debe considerar el plazo de prescripción de la deuda tributaria para que la información obtenida pueda ser utilizada en los procedimientos tributarios y judiciales, salvo disposición en contrario.

d) El intercambio sólo se debe realizara pedido y con la autoridad competente respectiva; en tal sentido la SUNAT no está obligada a efectuarlo cuando lo solicite un administrado.

e) En principio la información solo debe ser usada para los fines propios de la SUNAT conforme a sus competencias y facultades; sin perjuicio de las excepciones que expresamente se hubieran señalado en el acuerdo o convenio correspondiente y, siguiendo el procedimiento que se hubiera previsto para tal efecto, como es el obtener autorización previa de la autoridad competente del estado que proporciona la información para destinarla a otros fines. 
f) El intercambio de información calificada como datos personales conforme a la Ley N. ${ }^{\circ} 29733$ - Ley de Protección de Datos Personales, se encuentra sujeta a la autorización previa del interesado

g) Se consideran las tres modalidades de intercambio de información:;

i. Intercambio a requerimiento;

ii. Intercambio automático, en el cual la SUNAT debe suministrar periódicamente la información establecida en los convenios internacionales.

iii.Intercambio espontáneo, cuando la SUNAT en el ejercicio de sus facultades, considere que determinada información es relevante para la autoridad competente del otro estado

h) En el caso de las Fiscalizaciones Simultáneas y en el Extranjero, la SUNAT podrá acordar con las autoridades fiscales de los otros estados los lineamientos y acciones de fiscalización a llevar a cabo, cada uno en su propio estado y conforme a su legislación interna. Eventualmente pueden estar presentes representantes de las autoridades competentes extranjeras. De interponerse medios impugnatorios o solicitudes de compensación, SUNAT no es competente para resolver las mismas siendo ello competencia de las autoridades extranjeras.

i) En cuanto a la asistencia en la cobranza de la deuda y la adopción de medidas cautelares previas, se realizarán las acciones conducentes al recupero del monto de la deuda tributaria, incluyendo intereses, que conste en el documento oficial enviado por la autoridad competente extranjera y, las medidas cautelares previas se aplicarán si la autoridad extranjera lo solicita y en tanto existan razones para suponer que la cobranza pueda devenir en infructuosa conforme lo dispone el artículo 56 del CT.

j) Respecto a la asistencia en las notificaciones, se entiende que la notificación realizada por la autoridad extranjera según su legislación interna tiene la misma validez que la realizada por la SUNAT al amparo de las normas del CT sobre la materia.

\section{B) Facultades de la SUNAT en la Fiscalización:}

a) Solicitar información al sistema financiero sobre operaciones pasivas con sus clientes, incluyendo además del sujeto fiscalizado a los sujetos 
que guarden relación y que se encuentren vinculados con los hechos investigados. Asimismo la información deberá incluir a los beneficiarios finales.

b) Para la atención de intercambios de información que requieran el levantamiento del secreto bancario, el juez en un plazo de 48 horas deberá evaluar la solicitud que para tal efecto realice la administración.

C) Obligaciones de los Administrados

a) Permitir que la SUNAT realice las acciones referidas a AAMMT en cuanto a presentación y/o exhibición de información, concurrencia a las oficinas de SUNAT, presentación de declaraciones informativas, entre otras.

b) Las entidades que conforman el Sistema Financiero deberán presentar periódicamente información sobre las operaciones pasivas con sus clientes respecto a los saldos, montos acumulados promedios, rendimientos, sin que en ningún caso la información detalle los movimientos de la cuenta de las operaciones pasivas; así también debe proporcionar información que identifique a los clientes respecto al cumplimiento de lo acordado en tratados internacionales o decisiones de la Comunidad Andina.(Art. 143-A LGSF y artículo $87^{\circ} \mathrm{del} \mathrm{CT)}$

La información suministrada debe comprender la información de la titularidad e identidad del Beneficiario Final.

.En caso la SUNAT deba solicitar mayor información a la establecida en el art. 143-A de la LGSF, deberá enviar una solicitud al juez debidamente motivada.

c) Los miembros del Poder Judicial, Notarios y otros funcionarios deben informar a la SUNAT sobre temas relacionados a la AAMT de la que tengan conocimiento en el ejercicio de sus funciones.

\section{D) Infracciones y Sanciones vinculadas a la AAMMT}

a) Se tipifican como infracciones el incumplimiento de las obligaciones vinculadas con la AAMMT y, se establece que en la resolución de multa respectiva se deberá señalar el nombre del administrado obligado.

b) Monto de la multa: $40 \%$ UIT. 
c) Así mismo se dispone que el Tribunal Fiscal es competente para resolver las impugnaciones de las resoluciones de multa por incumplimiento de las obligaciones vinculadas con la AAMMT.

\section{E) Garantías para los Administrados}

a) Los derechos de los contribuyentes se extienden a todos los administrados, a fin de resguardar los derechos de aquellos que sin tener la condición de contribuyente para efecto del sistema tributario nacional, puedan ser sujetos de algún procedimiento referido a la AAMT.

b) Se reconoce la obligación del personal de la SUNAT a mantener la confidencialidad de la información proporcionada, señalando que de no hacerlo se generaría responsabilidad penal por el uso no autorizado o ilegal de la información.

c) La información reservada, conforme a lo dispuesto por el artículo $85^{\circ}$ del CT, podrá ser materia de intercambio, pero manteniendo su condición de reservada por lo que el estado receptor deberá adoptar las medidas para que así sea.

Como se puede apreciar, las modificaciones realizadas han sido bastante detalladas, con el objeto de evitar cualquier cuestionamiento respecto a las facultades y competencias de la administración para realizar acciones relacionadas a la asistencia administrativa mutua y, por ende en el intercambio de información, que puedan dilatar o le resten eficacia al proceso, incluso llegando a perjudicar los resultados que se obtengan en eventuales procedimientos judiciales, por ejemplo quitando el mérito probatorio de la información obtenida; más aún en lo referente a la facultad de requerir información incluso que no tenga interés para fines propios de la SUNAT, o la imposición de sanciones ante el incumplimiento de los requerimientos que se efectúen a efecto de atender las solicitudes de información que se formulen en el procedimiento de intercambio de información.

En tal sentido, aún cuando existen algunos temas pendientes de regulación, consideramos plausible las modificaciones realizadas a nuestra legislación.

\subsubsection{Disponibilidad de la información}

Una condición indispensable a efecto de asumir el compromiso de utilizar este mecanismo de cooperación internacional en materia fiscal como es el intercambio de información, es que el estado a través de su Administración Tributaria, cuente o esté en aptitud de obtener la información necesaria para la ejecución del procedimiento, lo cual 
incluye el disponer de información suficiente sobre la identidad de los sujetos que sean residentes o no y, el tipo de ingresos que perciben, las operaciones que realizan y el patrimonio que generan o mantienen en el territorio nacional.

En tal sentido resulta necesario revisar si nuestra legislación contempla esas posibilidades.

$\mathrm{Al}$ respecto cabe señalar que de acuerdo a nuestro ordenamiento jurídico existen una serie de registros, tanto de la identidad personal como de las empresas, en los cuales se puede encontrar información que puede ser materia de intercambio y, respecto de los cuales existe la obligación de comunicar cualquier cambio.

Así tenemos en el caso de las personas naturales el Registro Nacional de Identificación y Estado Civil (RENIEC). En el ámbito civil y comercial, para que una sociedad adquiera personería jurídica debe inscribirse en los Registros Públicos, para lo cual se debe constituir mediante Escritura Pública, en la que conste toda la información del pacto social de la misma, tales como los datos de identificación de sus accionistas, el monto de sus aportes y participaciones en el capital social, los estatutos de la sociedad en los que se señale el objeto para el cual se constituye. Cualquier modificación que se efectúe a estos documentos debe seguir la misma formalidad de escritura pública. Es importante destacar que en el Perú está prohibida la emisión de acciones al portador, lo cual constituye una condición favorable para efecto del intercambio de información. la Comisión Nacional Supervisora de Empresas y Valores,

En materia tributaria, tenemos el Registro Único del Contribuyente (RUC) en el cual debe inscribirse toda persona natural o jurídica que tenga la condición de contribuyente de los tributos que constituyan ingresos del Tesoro Público, a fin de obtener su número de identificación tributaria. Para tal efecto el contribuyente debe proporcionar información sobre su identificación, su domicilio fiscal, la actividad económica que realiza (tanto la principal como las secundarias), la fecha en que inició sus actividades, los tributos a los que se encuentra afecta, tratándose de sociedades, constituidas en el país o en el extranjero, adicionalmente deben informar sobres sus integrantes, la identidad de sus accionistas, de sus representantes legales, sus sucursales y establecimientos permanentes, la relación de sus trabajadores entre otros. Esta información debe mantenerse actualizada, pues existe la obligación a cargo del contribuyente de comunicar los cambios en la misma.

Un aspecto favorable también para la disponibilidad de información, es la existencia del sistema de prevención de lavado de activos a cargo de la Unidad de 
Inteligencia Financiera (UIF) en el que de acuerdo a los estándares internacionales por los convenios suscritos en esta materia, se ha establecido en nuestra legislación interna la obligación de toda persona natural o jurídica, incluyendo a las empresas que integran el Sistema Financiero y del Sistema de Seguros, ya sean de carácter público o privado de reportar a la UIF toda operación sospechosa de la que tomen conocimiento en el ejercicio de sus funciones o actividades.

En lo que se refiere a la información contable, cabe señalar que existe la obligación de llevar y mantener los registros contables tanto en disposiciones societarias como en las tributarias, siendo facultad de la administración tributaria exigir su exhibición y su revisión.

Si bien existe la institución de la reserva bursátil, esta no es oponible a la Administración Tributaria, en tanto que en el ejercicio regular de sus funciones tiene la facultad y respecto de casos concretos, de requerir la información por ella protegida.

En situación diferente se encuentra el derecho al secreto profesional, que también se encuentra constitucionalmente protegido numeral 18 del artículo $2^{\circ}$ de la Constitución Política del Perú) y sobre el cual no hay lineamientos legales o jurisprudenciales para su aplicación en el marco del intercambio de información automática ${ }^{38}$.

De otro lado la SUNAT cuenta con convenios de colaboración interinstitucional que le permiten acceder a la información que obren en los registros de otras entidades, como por ejemplo con la Sociedad de Mercado de Valores a fin de recibir información sobre Fondos de Inversión, o con Registros Públicos.

\subsubsection{El Secreto Bancario - Un nuevo enfoque}

Conforme a lo dispuesto en el segundo párrafo del numeral 5 del artículo $2^{\circ}$ de la Constitución Política del Perú (1993) el secreto bancario es un derecho de la persona protegido constitucionalmente, que puede ser levantado solo a pedido del juez, del Fiscal de la Nación, o de una comisión investigadora del Congreso con arreglo a ley y siempre que se refieran a un caso investigado.

Este es un derecho que tiene un desarrollo legal en cuanto a su contenido y que deriva del derecho a la intimidad al ser la expresión de su carácter económico, tal como lo ha establecido el Tribunal Constitucional en la sentencia sobre el Expediente N. ${ }^{\circ}$

\footnotetext{
${ }^{38} \mathrm{El}$ informe de la OCDE sobre la legislación peruana en el marco del intercambio de información indica esta preocupación, pues los límites del derecho al secreto profesional no se encuentran debidamente definidos. OCDE, Peer Review Report Phase 1 Legal and Regulatory Framework Peru.
} 
00004-2004-AI/TC al señalar que "El derecho fundamental a la intimidad, como manifestación del derecho a la vida privada sin interferencias legítimas, tiene su concreción de carácter económico en el secreto bancario y la reserva tributaria”.

Asimismo, en la referida sentencia se señala que como todo derecho fundamental, el derecho a la intimidad tiene un contenido esencial que no admite limitación alguna y, un contenido no esencial que si permite restricciones en tanto sean razonables y proporcionales; concluyendo que el carácter económico constituye el contenido no esencial del derecho a la intimidad.

En base a este razonamiento y a la línea jurisprudencial del mencionado Tribunal, se considera que el secreto bancario no es un derecho absoluto, por lo que admite limitaciones en base a los criterios de razonabilidad y proporcionalidad antes mencionados y en aras de proteger bienes o intereses jurídicos superiores, conforme a lo señalado en la propia norma constitucional al permitir su levantamiento en determinados casos y, de acuerdo a lo establecido en la sentencia sobre el Expediente N. ${ }^{\circ}$ 00009-2014$\mathrm{PI} / \mathrm{TC}$, en el sentido

... que es posible que estos derechos [el secreto bancario y la reserva tributaria] sean objeto de intervenciones en supuestos excepcionales... dicho listado no sólo no prohíbe, sino que, por el contrario, admite implícitamente la posibilidad de que tales derechos puedan ser limitados en aras de la satisfacción de otros bienes jurídico-constitucionales, siempre que las medidas adoptadas para tal efecto superen el test de proporcionalidad [STC 0004- 2004-Al/TC, fundamento 39].

Agrega el citado colegiado que la regla es "siempre el secreto o su confidencialidad, en tanto, que la publicidad, la excepción" y, que de acuerdo al test de proporcionalidad la medida que establezca una limitación debe atender un interés constitucionalmente legítimo, no ser una medida innecesaria y no ocasionar mayores aflicciones al derecho intervenido en comparación con la intensidad de la optimización del fin perseguido.

Como se puede apreciar, en la aludida sentencia del Expediente N. ${ }^{\circ} 0004-2004-$ $\mathrm{Al} / \mathrm{TC}$, el Tribunal reconoce como un interés constitucionalmente legítimo a "la actividad impositiva por parte de la Administración Tributaria, en aras de fiscalizar y garantizar el principio de solidaridad contributiva que le es inherente".

A decir de Delgado Ratto C. (2017) "El Tribunal ha vaciado de contenido el secreto bancario recogido constitucionalmente a fin de preferir el derecho a la solidaridad 
en la imposición frente al derecho individual a la intimidad económica.” (p 18), posición que no compartimos dado que como hemos visto el Tribunal lo que ha hecho es precisar los alcances del derecho, manteniendo su contenido referido al detalle de las operaciones pasivas de los administrados, así como también la garantía de su protección.

En este orden de ideas, se han modificado los articulo $140^{\circ}$ y $143^{\circ}$ de la LGSF que regulan el secreto bancario, señalando que la SUNAT tiene potestad para solicitar de manera directa información referida a las operaciones pasivas de los contribuyentes de manera agregada por cada uno; pero se mantiene el acceso indirecto para conocer el detalle de los movimientos, pues deberá seguir el procedimiento de levantamiento del secreto bancario mediante autorización judicial.

Así, los supuestos en los que no rige el secreto bancario conforme a lo dispuesto en el nuevo artículo $143^{\circ}$ de la LGSF son cuando la información es solicitada:

a) Por jueces y tribunales en el ejercicio de sus funciones y con especifica referencia a un proceso determinado;

b) Por la SUNAT, previa autorización judicial, sin perjuicio de la información periódica que deben suministrar las instituciones del sistema financiero a tenor de lo dispuesto en el numeral 10 del artículo $62^{\circ}$ del CT. Esta información solo podrá ser utilizada para el cumplimiento de lo acordado en los convenios internacionales o en las decisiones de la Comunidad Andina.

Es importante tener en cuenta que el secreto bancario es un derecho que le asiste tanto a las personas naturales como a las jurídicas, tal como lo ha establecido el Tribunal Constitucional en la sentencia sobre el Expediente N. ${ }^{\circ} 00009-2014-\mathrm{AI} / \mathrm{TC}{ }^{39}$.

Ahora bien, entendemos que un análisis profundo sobre la constitucionalidad de la norma en comentario va mas allá de los límites del presente trabajo; pero si reconocemos que el secreto bancario al ser un derecho reconocido por la Constitución Política del Perú, perfilará el marco en el que operará el intercambio de información en el país.

\subsubsection{La Reserva Tributaria}

Al igual que el secreto bancario, la reserva tributaria es un derecho constitucional de la persona contemplado en el segundo párrafo del numeral 5 del artículo $2^{\circ}$ de la

${ }^{39}$ Del 31.12.2004, emitida por la acción de inconstitucionalidad interpuesta contra la Ley N. ${ }^{\circ} 28194$ - Ley para la Lucha contra la Evasión y para la formalización de la Economía". 
Constitución Política del Perú (1993), derivado del derecho a la intimidad, específicamente en lo que se refiere a la intimidad económica. Este derecho implica la obligación de la Administración Tributaria de no divulgar la información que le ha sido proporcionada por el administrado en el marco de la relación jurídico tributaria y mantenerla con carácter de secreta.

En el artículo $85^{\circ}$ del TUO del Código Tributario, se establece que la cuantía y la fuente de las rentas, los gastos, la base imponible o, cualesquiera otros datos relativos a ellos, cuando estén contenidos en las declaraciones e información que la Administración Tributaria obtenga por cualquier medio de los contribuyentes, responsables o terceros tiene carácter de información reservada, y únicamente podrá ser utilizada por la Administración Tributaria para sus fines propios.

No obstante, y por disposición del propio artículo en su inciso h), se exceptúa de la reserva tributaria al intercambio de información reservada que se realiza con las Administraciones Tributarias de otros países en cumplimiento de lo acordado en convenios internacionales.

De igual manera se señala que es un derecho de los administrados la confidencialidad de la información proporcionada a la Administración Tributaria conforme a lo señalado en el referido artículo $85^{\circ}$.

Si bien el Tribunal Constitucional reconoce a la Reserva Tributaria como un bien constitucionalmente protegido, al igual que en el caso del secreto bancario, indica que no es un derecho absoluto y que no forma parte del contenido esencial del derecho a la intimidad, por lo que su limitación es posible en tanto se pretenda proteger otro bien del mismo o de mayor rango, “... sirviendo a fines constitucionalmente legítimos y siempre que se encuentren dentro de los márgenes de lo informado por la razonabilidad y la proporcionalidad." (Sentencia sobre el Expediente N. ${ }^{\circ}$ 2838-2009-PHD/TC, numeral 14).

En tal sentido, la reserva tributaria no es un impedimento para la realización del intercambio de información en la medida que el Estado receptor, en cumplimiento del principio de confidencialidad contemplado en los tratados suscritos, garantice la reserva de la información recibida y la destine para los fines convenidos.

\section{Evaluando la viabilidad de la actuación del Estado}


Resulta interesante aplicar al Perú el test, que se viera anteriormente, a efecto de determinar los aspectos de la actuación del Estado a través de la SUNAT, que ofrecen oportunidades de mejora.

a) Buena Administración

Conforme lo indicado previamente, la buena administración tiene como base la sujeción a la ley, debiéndose entender por tal no sólo a la ley formal sino también a los principios que inspiran el sistema tributario. Al respecto, en el marco tributario peruano si bien quedan algunos temas pendientes de definición, en términos generales vemos que se han tomado las previsiones a través de la adecuación de nuestra legislación a los entandares internacionales, a fin de contar con el sustento legal necesario para la implementación del procedimiento de intercambio de información en todas sus modalidades, disminuyendo las contingencias que pudieran presentarse en este ámbito.

b) Confidencialidad

Al respecto, la confidencialidad de la información proporcionada a la administración tributaria se encuentra garantizada a nivel constitucional a través de la institución de la Reserva Tributaria, la cual se desarrolla en el antes comentado artículo 85 del CT.

En ese sentido, en la ejecución del procedimiento de intercambio de información al amparo de los tratados celebrados por el Perú, los funcionarios de la administración tributaria están sujetos a una obligación de confidencialidad según la cual deben preservar esta reserva; es decir, el secreto de los documentos e información que lleguen a su conocimiento o su posesión en el curso de las funciones a su cargo; esta obligación inclusive alcanza a aquellas personas que por excepción y los procedimientos previstos en la misma norma, acceden a información reservada, como son las entidades del sistema bancario y financiero por los convenios de recaudación que celebran con la SUNAT. Las personas que vulneren esta reserva están sujetos a responsabilidad administrativa y, en algunos casos, hasta responsabilidad penal.

Como también se explicara, esta reserva solo podrá ser levantada conforme a los procedimientos establecidos en la propia norma constitucional, lo cual se ha previsto en los convenios celebrados. 
La información se utilizará para fines tributarios, esto incluye a las audiencias públicas en los tribunales, así como en las sentencias judiciales; en la medida que el tratado lo estipule y exista autorización expresa de la Autoridad Competente, la información se podrá utilizarse para otros fines.

No obstante, es imperativo para la SUNAT ponerse al nivel de las autoridades tributarias de países más desarrollados, no sólo en lo que se refiere a la calidad de la información a ser reportada, sino también en cuanto a los mecanismos de seguridad que deberá implementar a fin de resguardar la información recibida de las autoridades extranjeras y de la que se proporcione a estas, para lo cual se vienen realizando esfuerzos en ese sentido, así como en que los nuevos desarrollos informáticos consideren la posibilidad de obtener, procesar y conservar información que cumplan con el CRS, en lo que a información financiera se refiere, y con Formato de Transmisión Estándar para la información no financiera.

Sin embargo, aún se requiere de una serie de desarrollos que garanticen la operación de un sistema administrativo y de un sistema informático que contemplen los criterios de seguridad y confidencialidad establecidos por la OCDE.

c) Derecho a la información

Ninguno de los convenios internacionales celebrados por el Perú prevé la comunicación al contribuyente sobre el procedimiento de intercambio que se efectuará de su información. De igual manera, las normas de derecho interno que regulan este mecanismo, tampoco la consideran, aunque si bien de la lectura de algunas de las modificaciones introducidas al CT pareciera que podría hacerse de conocimiento tal situación, esto no se ha señalado de manera expresa.

d) Derecho de Contradicción

Vinculado al derecho de información, el derecho a contradicción es un derecho primario que le asiste al contribuyente y, que de ejercerlo deberá hacerlo con la debida motivación.

En este aspecto nuevamente constatamos una ausencia total de regulación, pues ni en el marco de los convenios ni en el CT se ha previsto el derecho ni los mecanismos para realizar la impugnación respectiva.

En nuestra opinión, el Estado peruano debe prever los mecanismos para que los contribuyentes puedan ejercer su derecho a contradicción; sin que ello signifique 
una traba burocrática al intercambio de información, por lo que será muy importante para el Estado peruano agilizar su aparato administrativo.

\section{Temas pendientes}

No obstante las recientes modificaciones antes señaladas, como hemos visto aún existen algunos aspectos que requieren ser regulados a efecto de que el Perú pueda cumplir con los compromisos internacionales asumidos ante el Foro Global sobre Transparencia e Intercambio de Información para fines tributarios de la OCDE, los cuales se comentaran a continuación:

\subsection{Beneficiario final - Definición}

Este término es de reciente data en nuestra legislación tributaria, por cuanto ha sido introducido en la última modificación al $\mathrm{CT}^{40}$, específicamente en los numerales 10 del artículo $62^{\circ}$ y 15.3 del artículo $87^{\circ}$ del mismo.

En el primer caso se menciona al beneficiario final, cuando se dispone que la información que la SUNAT puede solicitar a las Empresas del Sistema Financiero en el ejercicio de su facultad de fiscalización, también estará referida a los beneficiarios finales de las operaciones respectivas.

En el mismo sentido, el artículo $87^{\circ}$ del CT, que se encuentra referido a las obligaciones de los administrados, en su numeral 15.3 se establece que las Empresas del Sistema Financiero nacional y otras entidades deben presentar periódicamente a la SUNAT información sobre la identificación de las cuentas y de sus titulares, precisando que esto incluye la información de la identidad y de la titularidad del beneficiario final, lo que se realizará de acuerdo a lo que se establezca por Decreto Supremo, dado que a la fecha las empresas que se encuentran bajo la supervisión de la SBS cumplen con informar al citado beneficiario, en tanto que no ocurre lo mismo con las empresas no supervisadas por dicha entidad, como es el caso de las empresas bursátiles; en tal sentido dicho decreto supremo deberá establecer las disposiciones para la presentación de la declaración informativa a ls SUNAT.

No obstante, en ninguno de los dispositivos citados se define qué se entiende por Beneficiario Final.

Al respecto, cabe señalar sin embargo que en nuestra legislación existe dicha

${ }^{40}$ Decreto Legislativo N. ${ }^{\circ} 1315$. 
definición pero para efecto del Sistema de Prevención del Lavado de Activos y del Financiamiento del Terrorismo, con la finalidad de que las entidades financieras determinen la identidad del propietario de los recursos que se canalizan a través de ellas, los titulares de las cuentas y los usuarios de sus servicios. Así recogiendo las recomendaciones del Grupo de Acción Financiera Internacional (GAFI) respecto a uno de los principales temas del estándar internacional para combatir el lavado de dinero y el financiamiento del terrorismo, se señala que el beneficiario final es la persona o personas físicas que al final son dueños o controlan a un cliente $\mathrm{y} / \mathrm{o} \mathrm{la} / \mathrm{s}$ persona/s en cuyo nombre se realiza una transacción, se incluye a las personas que ejercen control efectivo último de una persona jurídica o de una relación jurídica.

De otro lado en el ámbito fiscal internacional encontramos en el MOCDE la referencia al término "beneficiario efectivo", a fin de limitar el uso de los beneficios relativos a dividendos, intereses y regalías ${ }^{41}$, pero sin que se considere una definición del término, ni en el texto del convenio ni en sus comentarios, lo que se encuentra son ejemplos de lo que no es un beneficiario efectivo, de cuyo análisis se puede concluir que para tener esa condición no importa el título bajo el cual se perciba el recurso o la renta, sino el poder de decisión sobre el destino del recurso, es decir tener su control, así como el poder de disfrutarlo y de asumir el riesgo del mismo.

Como se puede apreciar, aún cuando se utilicen diferentes denominaciones, nos encontramos frente a la misma figura, una persona generalmente natural, que ejerce poder sobre un activo, de tal manera que puede disponer del mismo de manera plena, y gozar de los rendimientos y beneficios económicos que este le genere.

Ahora bien, conforme al párrafo 132 de los Comentarios a la Sección VIII del Éstandar del CRS, el beneficiario final se equipara al beneficiario efectivo, que figura en la recomendación 10 y en la nota interpretativa sobre la recomendación 10 del GAFI.

En tal sentido, consideramos que se debiera adoptar la definición establecida en el Sistema de Prevención del Lavado de Activos y del Financiamiento del Terrorismo, a fin de homogenizar los conceptos permitiendo centralizar la información que es necesaria, aunar esfuerzos estableciendo sinergias y ahorrando recursos.

De igual manera, se considera conveniente la implementación de un Registro de Beneficiarios Finales que esté a cargo de la SUNAT, atendiendo a la naturaleza de este

${ }^{41}$ Contemplados en los artículos 10, 11 y 12 del referido modelo. 
concepto y sus implicancias tributarias, adicionalmente al hecho de que es la institución que requiere de la referida información para el ejercicio de sus funciones y que en materia de intercambio de información fiscal es la Autoridad Competente. Para tal efecto resulta necesario que se establezca la obligación de las personas jurídicas y otros entes jurídicos, de informar la identificación de sus beneficiarios finales y sus modificaciones a la administración tributaria.

Esta información tendrá el carácter de confidencial, permitiendo el acceso a ella a otras entidades públicas que por las funciones que les correspondan requieran contar con la misma, como es el caso de la SBS atendiendo a sus competencias vinculadas a la supervisión y análisis financiero de las empresas y de prevención de lavado de activos y financiamiento del terrorismo.

\subsection{Comentarios OCDE - Naturaleza y Aplicación}

Otros temas que requieren de precisión son los referidos a la naturaleza y el carácter de los Comentarios de la OCDE (entendiendo como tales de manera genérica a las directrices o las guías que las contienen), sobre de los convenios cuyos modelos impulsa esta organización, tanto de los CDI como de la CAMMT y los estándares establecidos en ellos a fin de facilitar su aplicación y, evitar conflictos atendiendo a las diferentes posiciones que existen en aspectos tales como si dichos Comentarios tienen carácter vinculante, ya sea que se trate de estados miembros o no de la referida organización, como es a la fecha el caso del Perú, así como la versión de los mismos que se debe utilizar habida cuenta de su carácter dinámico.

En principio debemos recordar que los tipos de convenios vistos a lo largo del presente trabajo, constituyen tratados de derecho internacional que se encuentran regulados por la Convención de Viena sobre el Derecho de los Tratados (1969).

Esta convención establece, entre otros aspectos, las reglas generales que se deberán observar en la interpretación de los tratados; así dispone en su artículo $31^{\circ}$ que este proceso se debe realizar atendiendo al principio de la buena fe, es decir de acuerdo al sentido corriente de las palabras utilizadas, en el contexto de las mismas y considerando su objeto y fin (numeral 1). Para tal efecto, añade que el contexto comprende el preámbulo del convenio así como sus anexos, los acuerdos celebrados y cualquier documento que se hubiera formulado con motivo del tratado (numeral 2), de igual modo indica que se deben considerar los acuerdos adoptados con posterioridad respecto a la 
interpretación o aplicación del tratado, así como las prácticas en este último aspecto (numeral 3) y, que solo se dará un sentido especial a los términos utilizados en la medida que conste que así fue la intención de las partes (numeral 4).

Igualmente, de manera subsidiaria a efecto de esclarecer el sentido de un tratado la referida Convención en su artículo $32^{\circ}$ considera la posibilidad de utilizar "Medios de interpretación complementarios", como son los trabajos preparatorios del mismo y las circunstancias de su celebración.

Por otro lado, tenemos que los Comentarios no son parte del texto del convenio que se suscribe. Estos Comentarios son "redactados y acordados por expertos que representan, en el seno del Comité de Asuntos Fiscales [que es el órgano principal en materia fiscal de la OCDE], a los Gobiernos de los países miembros" (Comité de Asuntos Fiscales, 2006, párrafo 15), por lo que se puede afirmar que constituyen una suerte de explicación consensuada de la interpretación y/o alcances del contenido de los convenios, con la finalidad de armonizar los criterios para la aplicación de lo en ellos estipulado en tanto se hubieran negociado y suscrito en base al convenio que comentan.

En tal sentido, tienen el carácter de recomendación, y se enmarcan en lo que la doctrina denomina el "soft law" para aquellos estados miembros de la OCDE. En cuanto para los estados que no son miembros, en la medida que hubieran utilizado el o los modelos de convenios impulsados por esta organización, en aplicación del principio de buena fe y en tanto no se hubiera señalado lo contrario, se debe asumir que estos Comentarios forman parte de los antecedentes del tratado y, por lo tanto constituyen parte del contexto del mismo.

En nuestro sistema jurídico, los tratados celebrados por el Estado peruano forman parte del derecho nacional (Constitución Política del Perú, artículo 56²) y constituyen fuentes del derecho tributario, tal como lo señala la Norma III del CT. En consecuencia, los Comentarios no tienen el carácter de norma jurídica, sino solo de una fuente de interpretación a tener en cuenta en la aplicación del tratado correspondiente.

Mención aparte, pero no por eso menos interesante, resulta la opción asumida por el legislador en materia del impuesto a la renta, específicamente en el inciso h) del artículo lo 32-A del Texto Único Ordenado de la Ley del Impuesto a la Renta, aprobado por Decreto Supremo N. ${ }^{\circ}$ 179-2004EF y modificatorias, en el sentido de haber regulado que para la interpretación de las disposiciones contenidas en el referido artículo sobre la determinación del valor de mercado de las transacciones entre partes vinculadas o con 
países o territorios de baja o nula imposición, norma de carácter interno y de aplicación al margen de la existencia de un convenio, constituyen una fuente de interpretación:

las Guías sobre Precios de Transferencia para Empresas Multinacionales y Administraciones Fiscales, aprobadas por el consejo de la Organización para la Cooperación y el Desarrollo Económico - OCDE, en tanto las mismas no se opongan a loa disposiciones aprobadas por esta Ley.

Como se puede apreciar, se admite la posibilidad de adoptar criterios de orden internacional señalados por una organización de la cual el Perú no es miembro y respecto de los cuales no se ha celebrado tratado alguno, para la aplicación de las normas domésticas en un contexto no necesariamente internacional o en el ámbito de un convenio; esto en virtud al mandato legal comentado, aunque de manera subordinada, en tanto que restringe su consideración a que no contravengan lo dispuesto en la referida ley.

En cuanto a la segunda interrogante, cuya respuesta es la que más controversias ha suscitado en el ámbito internacional, con relación a la versión de los Comentarios que se debe utilizar en la interpretación de un convenio, cabe tener en cuenta que el Comité de Asuntos Fiscales se encuentra permanentemente analizando y revisando los Comentarios materia de estudio a fin de mantenerlos actualizados y puedan cumplir con su objetivo. Esta revisión es un proceso de mejora progresiva, por lo que cada cierto tiempo y en la medida que se estime necesario, los Comentarios se complementan o adecúan. Si bien en un inicio este proceso se materializaba en una modificación integral de los Comentarios, desde la década de los noventa se han realizado exámenes parciales a las versiones de los Comentarios existentes.

Al respecto, a nivel doctrinario existen dos teorías denominadas: "estática" y "dinámica". La diferencia fundamental entre ellas estriba en que la primera considera que los Comentarios a tenerse en cuenta en la interpretación de un tratado, son aquellos que se encontraban vigentes durante la negociación y suscripción del mismo; mientras la segunda postula por la consideración de aquellos Comentarios que se encuentren vigentes al momento de aplicación del mismo, aún cuando estos sean posteriores a él.

Ahora bien, si partimos de la premisa de que los acuerdos plasmados en el texto del convenio expresan la verdadera intención de las partes, a la cual se ha arribado producto de la negociación realizada en un contexto determinado del que, como se viera 
con anterioridad, forman parte los Comentarios; y que el contenido de la teoría dinámica no encaja en ninguno de los supuestos de las reglas generales de interpretación de los tratados ni de los medios complementarios para tal efecto, contemplados en los artículos $31^{\circ}$ y $32^{\circ}$ de la Convención de Viena sobre el Derecho de los Tratados antes mencionada $\mathrm{y}$, al hecho que los nuevos lineamientos plasmados en los Comentarios posteriores pudieran implicar cambios sustanciales a lo pactado - lo cual incluso contraviene el principio de seguridad jurídica -, debemos adscribirnos a la teoría de la interpretación estática.

Sin embargo, la conclusión antes esbozada admite una excepción, cual es que el convenio expresamente contemple la posibilidad de una interpretación en base a los Comentarios modificados.

\subsection{Derechos del Contribuyente}

Como se ha podido apreciar, en este rubro no es mucho lo que se ha considerado en nuestra legislación ni en los tratados celebrados, pues no se ha contemplado la posibilidad de que al administrado se le comunique previamente el intercambio de información respecto del cual será objeto su información. Así mismo, tampoco se considera el recurso y el procedimiento que podría iniciar a efecto de ejercer su oposición, quedando en total indefensión ante la posibilidad de la vulneración de sus derechos.

Aún cuando expresamente no se encuentre considerado en nuestra Constitución Política el derecho del ciudadano a ser informado en estos casos, conforme a lo dispuesto en su artículo $3^{\circ}$ la enumeración realizada de los derechos fundamentales de la persona el capítulo correspondiente “... no excluye a los demás que la Constitución garantiza, ni otros de naturaleza análoga o que se fundan en la dignidad del hombre, o en los principios de soberanía del pueblo, del Estado democrático de derecho y de la forma republicana de gobierno". De igual manera, en la Ley N. ${ }^{\circ} 27444$ - Ley Procedimiento Administrativo General, en su artículo $76^{\circ}$ cuando se regula la colaboración entre entidades en el ámbito nacional, se señala expresamente en el numeral 76.4 que se deberá notificar al administrado en aquellos casos en que el pedido de colaboración se encuentre referido a información sobre él, dentro de los 3 días de recibido el requerimiento de información.

De acuerdo a Andonnino el contribuyente debería ser informado de la existencia de un requerimiento de información respecto a él, por una Administración Fiscal extranjera a fin de poder eventualmente oponerse a la entrega de la misma, haciendo valer 
sus razones en el curso de las investigaciones, (como se citó en Delgado Ratto, 2017, p.27).

De igual manera Merino y Nocete (2011) señalan que la legislación de cada país considera una vasta variedad de derechos y garantías para las personas afectadas por el intercambio de información, los cuales se concretan en los derechos de notificación, audiencia e intervención o impugnación de las medidas adoptadas por la parte requerida en la recopilación de la información, pudiendo incluso alegarse la ilegalidad de las pruebas ante los tribunales del Estado receptor de la información.

Ahora bien, es importante acotar que en el artículo $92^{\circ}$ del CT, conforme a su reciente modificación ${ }^{42}$, se recogen de manera enunciativa los derechos de los administrados, e indica que además de los expresamente señalados en él, los administrados pueden "ejercer los conferidos por la Constitución, por este Código o por leyes especiales".

En tal sentido, tratándose de derechos amparados constitucionalmente a efecto de impedir su vulneración, correspondería la interposición de la garantía constitucional de Habeas Data ${ }^{43}$, pues como señala Morales Godo uno de los objetivos del Habeas Data es exigir confidencialidad respecto de la información que obra en los registros, es decir impedir su divulgación (como se citó en Rubio Correa, 1999, p.101).

No obstante, al no tener conocimiento del procedimiento que se llevará a cabo, el administrado no podría interponer recurso alguno para impedir el intercambio.

Así, el intercambio de información sin comunicación previa al sujeto involucrado, es un tema bastante discutible en el ámbito jurídico dada la posible afectación de derechos de orden constitucional. Si bien se argumenta que podría dar pie a obstrucciones y dilaciones frente a la agilidad y rapidez que requiere el intercambio de información, en nuestra opinión no es conveniente para el desarrollo de un sistema tributario justo y transparente que se mantenga esta omisión, que a la larga más bien podría generar un rechazo al mecanismo con la consiguiente pérdida de legitimidad o, incluso el menoscabo de su efectividad. En ese sentido, creemos que el legislador peruano debe incluir las medidas correspondientes para que el contribuyente sea informado oportunamente sobre el intercambio de su información, previendo un mecanismo ágil que no dilate la realización del procedimiento y, por supuesto atendiendo a la modalidad del intercambio, pues

\footnotetext{
${ }^{42}$ Decreto Legislativo N. ${ }^{\circ} 1315$.

${ }^{43}$ Numeral 3 del artículo $200^{\circ}$ de la Constitución Política del Perú.
} 
diferente será la situación de un intercambio automático frente a uno a requerimiento o a un espontáneo.

Así, si bien en las modalidades a requerimiento y espontáneo existe una mayor margen para establecer la forma y oportunidad de efectivizar la comunicación al contribuyente; en la modalidad automática, se podría considerar la inclusión de una cláusula en los contratos que celebren los administrados con las entidades obligadas a reportar información a ser materia de intercambio, en la que se establezca la posibilidad de su transmisión a otros Estados por la ejecución de convenios de carácter internacional. De esta manera, se garantizará que el ejercicio de esta potestad se efectúe dentro del marco de la ley y respetando los derechos de los contribuyentes.

6.4. Obligación de las empresas del sistema financiero de declarar información

A efecto de la implementación del intercambio automático de información financiera en materia fiscal, conforme a lo dispuesto en el numeral 15 del artículo $87^{\circ}$ del $\mathrm{CT}$, se debe emitir un Decreto Supremo que regule el procedimiento para el cumplimiento de la obligación de las empresas del sistema financiero de proporcionar a la SUNAT información de las operaciones activas y pasivas de sus clientes.

En tal sentido es necesario establecer los alcances de dicha obligación, definir los sujetos obligados, dado que el concepto de instituciones financieras que considera el CRS es más amplio que el de empresas del sistema financiero a que se refiere la Ley N ${ }^{\circ} 26702$ - Ley General del Sistema Financiero y del Sistema de Seguros y Orgánica de la Superintendencia de Banca y Seguros, el contenido de la información a proporcionar respecto a las cuentas y datos que deben ser suministrados, la periodicidad y oportunidad de su presentación, así como del procedimiento de debida diligencia para identifica al beneficiario final a realizar atendiendo a los estándares del CRS. 


\section{CONCLUSIONES Y RECOMENDACIONES}

- Bajo las actuales circunstancias es innegable que el Intercambio de Información es una herramienta indispensable para el accionar de la Administración Tributaria a efecto de la correcta determinación de la obligación tributaria y proveer al Estado de los ingresos suficientes así como lograr un sistema tributario justo.

- A diferencia de otros Estados de la región latinoamericana, el Perú cuenta con una red de tratados limitada, consistente sólo en ocho tratados, por lo que el intercambio de información en Perú se encuentra bastante restringido.

- El intercambio de información Automático como nuevo estándar es la mejor modalidad de intercambio de información, por su carácter tecnológico (acorde con la era digital) y, ser más eficiente que el Intercambio de Información a Requerimiento y menos discrecional que el Intercambio de Información Espontáneo. De este modo, el Intercambio de Información Automático demuestra ser una opción viable por su equilibrio entre el respeto a la soberanía de los Estados y la cooperación.

- En este sentido, y atendiendo a la importancia del intercambio de información resulta necesario que se amplíe la red de convenios específicos para lo cual sería conveniente que el Perú suscriba la "Convención sobre Asistencia Administrativa Mutua en Materia fiscal" - CAAMMT, dada la cantidad de estados que involucra la misma, así como el acuerdo para implementar el Common Reporting Standard - CRS y poner en práctica el intercambio automático de información financiera a efectos tributarios.

- Sin embargo, cabe resaltar que para adherirse, a fin de que los estados puedan adoptar dichas propuestas, es necesario implementar los estándares establecidos en la CAMMT, así como los "Estándares para el intercambio automático de 
información financiera a efectos fiscales tributarios", ya que dicho intercambio reposa en el principio de reciprocidad.

- Para tal efecto se debe reforzar en la administración tributaria: tecnologías de información, comunicación y recursos humanos a fin de disminuir la brecha de la eficiencia con las administraciones tributarias de los estados que integran la OCDE.

- En el plano operativo es necesaria la implementación de un eficiente sistema informático que además de homologar las plataformas tecnológicas, otorgue la garantía del manejo confidencial de la información. Asimismo, se deben establecer procedimientos ágiles para la obtención y entrega de información materia de intercambio.

- Se debe diseñar estrategias para que el intercambio de información constituya un elemento a ser considerado como una práctica habitual en los procedimientos de auditoría o fiscalización y no algo excepcional.

- Asimismo, se debe implementar programa de capacitación para los funcionarios que deberán llevar a cabo los procesos de recolección de información materia del intercambio, así como sensibilizarlos funcionarios en las bondades del uso de esta herramienta.

- No se contempla de manera enfática los límites al intercambio de la información, lo que resulta de gran importancia a efecto de legitimar el procedimiento y asegurar la continuidad del mismo..

- En ese sentido se debe incorporar en la legislación la obligación expresa de comunicar al contribuyente la existencia de un requerimiento de información que lo involucra, aún cuando no sea necesaria su participación para la obtención de la información solicitada, a efecto que pueda verificar el cumplimiento del debido proceso en la obtención y transmisión de su información.

- De igual manera cuando la Administración Tributaria utilice información proporcionada por otro estado a través del proceso de intercambio de información se deberá informar al contribuyente para que se encuentre en aptitud de ejercitar su derecho de defensa.

- Asimismo, debe preverse legislativamente el recurso y el procedimiento para efecto de las impugnaciones que pueda realizar el administrado en salvaguarda de sus derechos. 
- A fin que la ciudadanía tome conocimiento de la implementación de estos mecanismos y, de la eventual posibilidad de ser sujeto de los mismos, especialmente en la modalidad del intercambio automático, la Administración Tributaria debe realizar una campaña de difusión y orientación respecto a los alcances del procedimiento y las acciones que puedan llevar a cabo los ciudadanos que vean afectados sus derechos.

- A nivel normativo se debe emitir las normas correspondientes que regulen los aspectos que se encuentran pendientes como son el concepto de beneficiario final, el contenido de la información que las empresas del sistema financiero deben proporcionar a la SUNAT respecto de las operaciones activas y pasivas de sus clientes, así como el procedimiento para cumplir con dicha obligación, considerando los lineamientos establecidos en los estándares del CRS. 


\section{REFERENCIAS}

Bentley, D. (2015). "Revisiting rights theory and principles to prepare for growing globalization and uncertainty". International Conference on Taxpayer Rights, Washington DC, November 18-19, 15.

Brzeziski, B.(2009). “Taxpayers' Rights: Some Theoretical Issues”, in Nykiel W. and Sek, W.N.M. (Eds.), Protection of Taxpayer's Rights: European, International and Domestic Tax Law Perspective (pp. 17 - 19). Warsaw: Wolter Kluwer

Calderón, J., Martín, A., Monserrat, V.(2008). “Convenios fiscales internacionales y fiscalidad de la Unión Europea”. Valencia. Edición Fiscal CISS.

Debelva, F. y Diepvens, N.(2016) "Exchange of information. An analysis of the scope of article 26 OECD Model and its requirements: In search for an efficient but balanced procedure". Intertax, Volume 44, Holanda.

Delgado, C. (2017). "La protección de los derechos de los contribuyentes en el proceso de intercambio de información en materia tributaria”. 9no Encuentro Regional Latinoamericano de la International Fiscal Association. Buenos Aires. 31 de mayo al 12 de junio

Kemmeren, E. (2006). "Source of Income in Globalizing Economies: Overview of the Issues and a Plea for an Origin-Based Approach". Bulletin for International Taxation. Vol. 60, No. 11. (pp.430-452).

Lang, M. (2013). Introduction to the Law on Double Tax Conventions. (2da Edición). Holanda: Themis.

Merino, M, y Nocete, F. (2011) El Intercambio de Información Tributaria: Entre la diversidad normativa, la imprecisión conceptual y la pluralidad de interés. Crónica Tributaria N. ${ }^{\circ}$ 139/2011 (p. 160) 
Patón, G. (2011). "La Dimensión del Intercambio de Información en los Convenios Fiscales Internacionales". En Collado, M.A. (dir.), Intercambio Internacional de información Tributaria: Avances y Proyección futura. Navarra: Thomson Reuters.

Red de Justicia Fiscal de América Latina y el Caribe (2015).Lima. Impresión Arte Perú S.A.C. "ABC de la Justicia Tributaria".

Rodríguez-Bereijo, M. (Julio 2012). "El intercambio de información fiscal entre los Estados y su incidencia probatoria". En Dret Revista para el análisis del derecho. Recuperado el 18 de enero, de www.INDRET.COM .

Rubio Correa, M. (1999). Estudio de la Constitución Política de 1993. Tomo VI. Lima. Pontificia Universidad Católica del Perú Fondo Editorial. 


\section{BIBLIOGRAFÍA}

Arias, A. Luis. (2011). “Política Tributaria para el 2011-2016”, en Economía y Sociedad, No. 77. Lima

Bacarat, E. (2013). Sustaining Trade Reform: Institutional Lesson from Argentina and Peru. The World Bank. Recuperado el 28 de noviembre de 2016, de http://wwwds.worldbank.org

Bell, Arthur. What is the difference between the two Model IGAs and which countries have signed them?. Recuperado el 5 de febrero del 2017, de http://www.arthurbellcpas.com/difference-between-the-two-model-igas/

Bentley, D. (2015). "Revisiting rights theory and principles to prepare for growing globalization and uncertainty". International Conference on Taxpayer Rights, Washington DC, November 18-19, 15.

Brzeziski, B.(2009) “Taxpayers’ Rights: Some Theoretical Issues”, en Nykiel W. and Sek, W.N.M. (eds.). Protection of Taxpayer's Rights: European, International and Domestic Tax Law Perspective.Warsaw: Wolter Kluwer.

Carbajo, D.y Porporatto, P. (2013). “Avances en materia de transparencia e intercambio de información tributaria". Revista de Administración Tributaria CIAT/AEAT/IEF, Nro. 35. Madrid.

CIAT. (2006). Manual CIAT para la implantación y práctica del intercambio de información para fines tributarios - Aspectos Generales y Legales del intercambio de información. Recuperado el 18 de agosto de 2016, dehttp://www.ciat.org. 
CIAT. (2015). Modelo del Código Tributario del CIAT: Un enfoque basado en la experiencia Iberoamericana. Panamá: CIAT.

Collado, M.A., et al. (2012). Estudios sobre el fraude fiscal e intercambio de información tributaria. Recuperado el 21 de agosto de 2016, de https://books.google.com.pe.

Comité de Asuntos Fiscales de la OCDE. (2006, 23 de enero). Manual para la aplicación de las disposiciones relativas al intercambio de información con fines tributario. Recuperado el 20 de agosto de 2016, de http://www.oecd.org.

Comité de Asuntos Fiscales de la OCDE. (2006). Modelo de Convenio Tributario sobre la Renta y sobre el Patrimonio. Versión abreviada del 15 de julio de 2005. Madrid: Instituto de Asuntos Fiscales.

Confédération Fiscale Européenne, Taxpayer Charter Press Release (Comunicado de Prensa del Código del Contribuyente Tributario) del 13.11.15

Convención de Viena sobre el Derecho de los Tratados. (23 mayo 1969). Recuperado el 15 de enero de 2017, de http://www.oas.org

Cordón Ezquerro, T., et al. (2004). Manual de fiscalidad internacional. Madrid: Instituto de Estudios Fiscales.

Cordón Ezquerro, T. (2014). "Los derechos de los contribuyentes en el intercambio de información entre Administraciones Tributarias". Revista de la Facultad de Derecho de la PUCP, Nro. 72. Lima.

Debelva, F. y Diepvens, N.(2016) "Exchange of information. An analysis of the scope of article 26 OECD Model and its requirements: In search for an efficient but balanced procedure". Intertax, Volume 44, Holanda.

Fraga, D. (2011). Tratado de la Información Tributaria. Buenos Aires. La Ley 
Global Forum on Transparency and Exchange of information for Tax Purposes. (2016, 20 de agosto). Exchange of information working manual. Recuperado el 20 de agosto de 2016, de http://www.oecd.org.

IRS. FATCA: Foreign Account Tax Compliance Act. Recuperado el 15 de enero del 2017, de https://www.treasury.gov

Kemmeren, E.C.C.M. "Source of Income in Globalizing Economies: Overview of the Issues and a Plea for an Origin-Based Approach”, BIT (60) 2006/11.

Lang, M. (2013). Introduction to the Law on Double Tax Conventions. (2da Edición). Holanda: Themis.

Martín, B. (2010). “Los acuerdos de intercambio de información”. Cuadernos de Formación del Instituto de Estudios Fiscales, Vol. 10. Madrid.

Merino, M. y Nocete, F. J. (2011). El intercambio de información tributaria en el Derecho internacional, Europeo y Español. Recuperado el 21 de agosto de 2016, de http://www.ief.es.

Merino, M. y Nocete, F. J. (2011). "El intercambio de información tributaria: Entre la diversidad normativa, la imprecisión conceptual y la pluralidad de intereses".Crónica Tributaria. Nro. 139. Madrid

OCDE. (2006). Manual on the implementation of exchange of information provisions for tax purposes. París: OECD Publishing

OECD. (2015). Action 13: Guidance on the Implementation of Transfer Pricing Documentation and Country-by-Country Reporting. París:OECD Publishing

OECD.(2013). Action Plan on Base Erosion and Profit Shifting. París: OECD Publishing 
OECD. (2016). Exchange of Information on Request: Handbook for peer reviews 20162020 (Global forum on transparency and exchange of information for tax purposes, Paris: OECD-Committee of Fiscal Affairs (CFA) 201620.01.2016.

OECD. (2014). Commentary OECD. Recuperadoel 15 de enero de 2016, de http://www.keepeek.com

OECD. (2014). Model Convention. París: OECD Publishing

OECD.(2015). Multilateral Competent Authority Agreement On The Exchange Of Country-By-Country Reports. Paris: OECD - Committee of Fiscal Affairs (CFA)

OECD. (2016). Standard for Automatic Exchange of Financial Account Information Common Reporting Standard. París: OECD Publishing

OECD (2015). Supra 24. "Aligning Transfer Pricing Outcomes with Value Creation, Actions 8-10 - 2015 Final Reports”. París: OECD Publishing.

OECD. (1990). Taxpayers' Rights and Obligations: A Survey of the Legal Situation in OECD Countries. París: OECD Publishing

OECD. (2008). Study into the role of tax intermediaries. París: OECD Publishing

ONU (2011) Model Convention.París: OECD Publishing

Osorio M., L.H. (2016). “Los Panama Papers Leaks y la Planificación Fiscal ¿Quién gana en este juego?”. En Revista Análisis Tributario. N. ${ }^{\circ} 339$

Patón García G. (2011). “La Dimensión del Intercambio de Información en los Convenios Fiscales Internacionales", en Collado Yurrita, M.A. (dir.). Intercambio Internacional de información Tributaria: Avances y Proyección futura. Navarra: Thomson Reuters. 
Pecho, M. (2014). "El intercambio de información: hacia el nuevo estándar de transparencia fiscal internacional". Revista de la Facultad de Derecho de la $P U C P$, Nro. 72. Lima.

Pita, C. (2007). El intercambio de informaciones tributarias como instrumento de contención de la competencia desleal a nivel internacional. Recuperado el 21 de agosto de 2016, de http://www.cepal.org.

Rodríguez-Bereijo, M. (Julio 2012). "El intercambio de información fiscal entre los Estados y su incidencia probatoria”. In Dret Revista para el análisis del derecho. Recuperado el 18 de enero, de www.INDRET.COM .

Rosembuj, T. (2004). Intercambio internacional de información tributaria. Barcelona: Edicons Barcelona.

Rosembuj, T. (2012). Principios globales de fiscalidad internacional. Barcelona: El Fisco.

Rubio Guerrero, J., et al. (2016). Manual de fiscalidad internacional (4ª . Ed.). Madrid: Instituto de Estudios Fiscales.

Sánchez, M.E. (2009). "El suministro de información como medio de realización de la justicia tributaria". Revista Peruana de Derecho Tributario, Nro. 13. Lima

Serrano Antón, F., y Palao Taboada, C. (2007). Fiscalidad internacional. Madrid: Centro de Estudios Financieros.

Talledo, C. (2016). Manual del Código Tributario. Lima: Editorial Economía y Finanzas S.R.L.

Valdez, P. (2015). "Los Acuerdos de intercambio de Información Tributaria y su Implementación en el Perú”. Revista Derecho \& Sociedad, Vol. 43. Lima. 


\section{Sitios Web}

http://en.euabc.com/word/506

http://www.oecd-ilibrary.org/taxation/model-tax-convention-on-income-and-on-capitalcondensed-version_20745419

http://www.keepeek.com/Digital-Asset-Management/oecd/taxation/model-taxconvention-on-income-and-on-capital-2015-full-version_9789264239081-en\#page1066 https://www.treasury.gov/resource-center/tax-policy/treaties/Pages/FATCA.aspx http://www.oecd.org/tax/exchange-of-tax-information/Status_of_convention.pdf http://www.oecd.org/tax/automatic-exchange/commitment-and-monitoringprocess/AEOI-commitments.pdf http://www.cfeeutax.org/sites/default/files/Press\%20Release_A\%20Model\%20Taxpaye r\%20Charter\%20CFE\%20version\%20FINAL.pdf

http://www.sunat.gob.pe

http://worldtaxpayers.org/ 
ANEXO I

INTERCAMBIO DE INFORMACIÓN EN CONVENIOS SUSCRITOS POR EL PERÚ - COMPARATIVO

\begin{tabular}{|c|c|c|c|c|c|c|}
\hline \multicolumn{3}{|c|}{ MOCDE 2003} & \multicolumn{4}{|c|}{ MOCDE 2010} \\
\hline $\begin{array}{c}\text { CHILE } \\
\text { Aplicable a partir del } \\
\text { 01.01.2004 }\end{array}$ & $\begin{array}{c}\text { CANÁDA } \\
\text { Aplicable a partir del } \\
\text { 01.01.2004 }\end{array}$ & $\begin{array}{c}\text { BRASIL } \\
\text { Aplicable a partir del } \\
\text { 01.01.2010 }\end{array}$ & $\begin{array}{c}\text { MÉXICO } \\
\text { Aplicable a partir del } \\
\text { 01.01.2015 }\end{array}$ & $\begin{array}{c}\text { COREA DEL SUR } \\
\text { Aplicable a partir del } \\
\text { 01.01.2015 }\end{array}$ & $\begin{array}{c}\text { SUIZA } \\
\text { Aplicable a partir del } \\
\text { 01.01.2015 }\end{array}$ & $\begin{array}{c}\text { PORTUGAL } \\
\text { Aplicable a partir del } \\
\text { 01.01.2015 }\end{array}$ \\
\hline $\begin{array}{ll}\text { Artículo } & 2^{\circ} \\
\text { INTERCAMBIO } & \text { DE } \\
\text { INFORMACIÓN } & \\
\end{array}$ & $\begin{array}{ll}\text { ARTÍCULO } & 2^{\circ} \\
\text { INTERCAMBIO } & \text { DE } \\
\text { INFORMACIÓN } & \\
\end{array}$ & $\begin{array}{l}\text { ARTÍCULO 25 } \\
\text { INTERCAMBIO DE } \\
\text { INFORMACIÓN }\end{array}$ & $\begin{array}{l}\text { ARTÍCULO 26 }^{\circ} \\
\text { INTERCAMBIO DE } \\
\text { INFORMACIÓN }\end{array}$ & $\begin{array}{l}\text { ARTÍCULO 25 } \\
\text { INTERCAMBIO DE } \\
\text { INFORMACIÓN }\end{array}$ & $\begin{array}{ll}\text { ARTÍCULO } & 25^{\circ} \\
\text { INTERCAMBIO } & \text { DE } \\
\text { INFORMACIÓN } & \\
\end{array}$ & $\begin{array}{l}\text { ARTÍCULO 25 }^{\circ} \\
\text { INTERCAMBIO } \\
\text { INFORMACIÓN }\end{array}$ \\
\hline $\begin{array}{l}\text { 1. Las autoridades } \\
\text { competentes de los } \\
\text { Estados Contratantes } \\
\text { intercambiarán las } \\
\text { informaciones } \\
\text { necesarias para aplicar } \\
\text { lo dispuesto en el } \\
\text { presente Convenio, o en } \\
\text { el derecho interno de los } \\
\text { Estados Contratantes } \\
\text { relativo a los impuestos } \\
\text { comprendidos en el } \\
\text { Convenio en la medida } \\
\text { en que la imposición } \\
\text { prevista en el mismo no } \\
\text { sea contraria al } \\
\text { Convenio, la que podrá } \\
\text { ser utilizada para } \\
\text { determinar el impuesto }\end{array}$ & $\begin{array}{l}\text { 1. Las autoridades } \\
\text { competentes de los } \\
\text { Estados Contratantes } \\
\text { intercambiarán las } \\
\text { informaciones } \\
\text { necesarias para aplicar } \\
\text { lo dispuesto en el } \\
\text { presente Convenio, o en } \\
\text { el derecho interno de los } \\
\text { Estados Contratantes } \\
\text { relativo a los impuestos } \\
\text { comprendidos en el } \\
\text { Convenio en la medida } \\
\text { en que la imposición } \\
\text { prevista en el mismo no } \\
\text { sea contraria al } \\
\text { Convenio. } \\
\text { intercambio El } \\
\text { información no se verá }\end{array}$ & $\begin{array}{l}\text { 1. Las autoridades } \\
\text { competentes de los } \\
\text { Estados Contratantes } \\
\text { intercambiarán las } \\
\text { informaciones } \\
\text { necesarias para aplicar } \\
\text { lo dispuesto en el } \\
\text { presente Convenio o en } \\
\text { el derecho interno de los } \\
\text { Estados Contratantes } \\
\text { relativo a los impuestos } \\
\text { de cualquier especie y } \\
\text { descripción exigidos } \\
\text { por cuenta de los } \\
\text { Estados Contratantes } \\
\text { en la medida en que la } \\
\text { imposición prevista en } \\
\text { el mismo no sea } \\
\text { contraria al }\end{array}$ & $\begin{array}{l}\text { 1. Las autoridades } \\
\text { competentes de los } \\
\text { Estados } \\
\text { Contratantes } \\
\text { intercambiarán las } \\
\text { informaciones que } \\
\text { previsiblemente sean } \\
\text { relevantes para aplicar } \\
\text { lo dispuesto en el } \\
\text { presente Convenio, o en } \\
\text { el derecho interno de los } \\
\text { Estados Contratantes } \\
\text { relativo a los impuestos } \\
\text { de cualquier } \\
\text { especie y descripción } \\
\text { exigidos por cuenta de } \\
\text { los Estados }\end{array}$ & $\begin{array}{l}\text { 1. Las autoridades } \\
\text { competentes de los } \\
\text { Estados contratantes } \\
\text { intercambiarán la } \\
\text { información } \\
\text { previsiblemente } \\
\text { pertinente para aplicar } \\
\text { lo dispuesto en el } \\
\text { presente Convenio o } \\
\text { para administrar y } \\
\text { exigir lo dispuesto en la } \\
\text { legislación nacional de } \\
\text { los Estados contratantes } \\
\text { relativa a los impuestos } \\
\text { de toda clase y } \\
\text { naturaleza percibidos } \\
\text { por los Estados } \\
\text { contratantes, r sus } \\
\text { subdivisiones ra }\end{array}$ & $\begin{array}{l}\text { 1. Las autoridades } \\
\text { competentes de los } \\
\text { Estados Contratantes } \\
\text { intercambiarán la } \\
\text { información } \\
\text { previsiblemente } \\
\text { pertinente para aplicar } \\
\text { lo dispuesto en el } \\
\text { presente Convenio o } \\
\text { para administrar o } \\
\text { exigir lo dispuesto en el } \\
\text { derecho interno de los } \\
\text { Estados Contratantes } \\
\text { relativo a los impuestos } \\
\text { cubiertos por este } \\
\text { Convenio, en la medida } \\
\text { en que la imposición } \\
\text { prevista en el mismo no } \\
\text { sea contraria al }\end{array}$ & $\begin{array}{l}\text { 1. Las autoridades } \\
\text { competentes de los } \\
\text { Estados Contratantes } \\
\text { intercambiarán } \\
\text { información } \\
\text { previsiblemente } \\
\text { pertinente para aplicar lo } \\
\text { dispuesto en el presente } \\
\text { Convenio o para } \\
\text { administrar y exigir lo } \\
\text { dispuesto en la legislación } \\
\text { nacional de los Estados } \\
\text { Contratantes relativa a los } \\
\text { impuestos de toda clase y } \\
\text { naturaleza percibidos por } \\
\text { los Estados Contratantes, } \\
\text { sus subdivisiones } \\
\text { políticas o administrativas } \\
\text { o entidades locales, en la }\end{array}$ \\
\hline
\end{tabular}




\begin{tabular}{|c|c|c|c|c|c|c|}
\hline $\begin{array}{l}\text { al valor agregado } \\
\text { (Impuesto General a las } \\
\text { Ventas). El intercambio } \\
\text { de información no se } \\
\text { verá limitado por el } \\
\text { Artículo } 1 . \text { las } \\
\text { sentencias judiciales }\end{array}$ & $\begin{array}{l}\text { limitado por el Artículo } \\
1 .\end{array}$ & $\begin{array}{lr}\text { Convenio. } & \text { El } \\
\text { intercambio } & \text { de } \\
\text { información no se verá } \\
\text { limitado por los } \\
\text { Artículos 1 y } 2 .\end{array}$ & $\begin{array}{l}\text { Contratantes, en la } \\
\text { medida en que la } \\
\text { imposición prevista } \\
\text { en el mismo no sea } \\
\text { contraria al Convenio. } \\
\text { El intercambio de } \\
\text { información no se verá } \\
\text { limitado por los } \\
\text { Artículos } 1 \text { y } 2 \text {. }\end{array}$ & $\begin{array}{l}\text { entidades locales en la } \\
\text { medida en que la } \\
\text { imposición prevista en } \\
\text { el mismo no sea } \\
\text { contraria al Convenio. } \\
\text { El intercambio de } \\
\text { información no vendrá } \\
\text { limitado por los } \\
\text { Artículos } 1 \text { y } 2 \text {. }\end{array}$ & $\begin{array}{l}\text { Convenio. } \\
\text { intercambio } \\
\text { información no se verá } \\
\text { limitado por el Artículo } \\
1 .\end{array}$ & $\begin{array}{l}\text { medida en que la } \\
\text { imposición prevista en el } \\
\text { mismo no sea contraria al } \\
\text { Convenio. El intercambio } \\
\text { de información no vendrá } \\
\text { limitado por los artículos } \\
1 \text { y } 2 \text {. }\end{array}$ \\
\hline $\begin{array}{l}\text { Las informaciones } \\
\text { recibidas por un Estado } \\
\text { Contratante serán } \\
\text { mantenidas en secreto } \\
\text { en igual forma que las } \\
\text { informaciones } \\
\text { obtenidas en base al } \\
\text { derecho interno de ese } \\
\text { Estado y sólo se } \\
\text { comunicarán a las } \\
\text { personas o autoridades } \\
\text { (incluidos los tribunales } \\
\text { y órganos } \\
\text { administrativos) } \\
\text { encargadas de la gestión } \\
\text { o recaudación de los } \\
\text { impuestos en el } \\
\text { comprendidos en } \\
\text { Convenio, de los } \\
\text { procedimientos } \\
\text { declarativos } \\
\text { ejecutivos relativos a } \\
\text { dichos impuestos, o de } \\
\text { la resolución de los }\end{array}$ & $\begin{array}{l}\text { Las informaciones } \\
\text { recibidas por un Estado } \\
\text { Contratante serán } \\
\text { mantenidas en secreto } \\
\text { en igual forma que las } \\
\text { informaciones } \\
\text { obtenidas en base al } \\
\text { derecho interno de ese } \\
\text { Estado y sólo se } \\
\text { comunicarán a las } \\
\text { personas o autoridades } \\
\text { (incluidos los tribunales } \\
\text { y órganos } \\
\text { administrativos) } \\
\text { encargadas de, y sólo } \\
\text { para el uso en relación } \\
\text { con, la gestión o } \\
\text { recaudación, los } \\
\text { procedimientos } \\
\text { declarativos o } \\
\text { ejecutivos relativos a } \\
\text { cualquier impuesto, o la } \\
\text { resolución de los } \\
\text { recursos relativos a los }\end{array}$ & $\begin{array}{l}\text { Las informaciones } \\
\text { recibidas por un Estado } \\
\text { Contratante serán } \\
\text { mantenidas en } \\
\text { secreto en igual forma } \\
\text { que las informaciones } \\
\text { obtenidas con base al } \\
\text { derecho } \\
\text { interno de ese Estado y } \\
\text { sólo se comunicarán a } \\
\text { las personas o } \\
\text { autoridades } \\
\text { (incluidos los tribunales } \\
\text { y órganos } \\
\text { administrativos) } \\
\text { encargadas de la gestión } \\
\text { o de los } \\
\text { recaudación de } \\
\text { impuestos } \\
\text { comprendidos en el } \\
\text { Convenio o en el } \\
\text { derecho } \\
\text { interno conforme a la } \\
\text { definición establecida }\end{array}$ & $\begin{array}{l}\text { 2. La información } \\
\text { recibida por un Estado } \\
\text { Contratante } \\
\text { en virtud del párrafo } 1 \\
\text { será mantenida en } \\
\text { secreto de la misma } \\
\text { forma que la } \\
\text { información obtenida } \\
\text { en virtud del } \\
\text { derecho interno de ese } \\
\text { Estado y sólo se } \\
\text { comunicará a las } \\
\text { personas o autoridades } \\
\text { (incluidos tribunales y } \\
\text { órganos la } \\
\text { administrativos) } \\
\text { encargadas de } \\
\text { liquidación o la } \\
\text { recaudación de los } \\
\text { impuestos a los que } \\
\text { hace referencia } \\
\text { el párrafo 1, de su } \\
\text { aplicación efectiva o de } \\
\text { la persecución }\end{array}$ & $\begin{array}{l}2 . \\
\text { información recibida } \\
\text { por un } \\
\text { Contratante en virtud } \\
\text { del párrafo } 1 \text { será } \\
\text { mantenida en secreto de } \\
\text { la misma forma que la } \\
\text { información obtenida } \\
\text { en virtud del derecho } \\
\text { interno de ese Estado y } \\
\text { sólo se comunicará a las } \\
\text { personas o autoridades } \\
\text { (incluidos los tribunales } \\
\text { y órganos } \\
\text { administrativos) } \\
\text { encargadas de la } \\
\text { liquidación o do } \\
\text { recaudación de los } \\
\text { impuestos efectiva, de } \\
\text { la persecución de su } \\
\text { incumplimiento o de la } \\
\text { resolución de los } \\
\text { recursos en relación con } \\
\text { los mismos. Dichas }\end{array}$ & $\begin{array}{l}2 . \\
\text { información recibida } \\
\text { por un } \begin{array}{r}\text { Estado } \\
\text { Contratante en virtud }\end{array} \\
\text { del párrafo } 1 \text { será } \\
\text { mantenida en secreto de } \\
\text { la misma forma que la } \\
\text { información obtenida } \\
\text { en virtud del derecho } \\
\text { interno de ese Estado y } \\
\text { sólo se comunicará a las } \\
\text { personas o autoridades } \\
\text { (incluidos los tribunales } \\
\text { y órganos } \\
\text { administrativos) } \\
\text { encargadas de la } \\
\text { liquidación } \\
\text { recaudación de los } \\
\text { impuestos a los que } \\
\text { hace referencia el } \\
\text { párrafo 1, de su } \\
\text { aplicación efectiva, de } \\
\text { la persecución de su } \\
\text { incumplimiento o de la }\end{array}$ & $\begin{array}{l}\text { 2. Cualquier información } \\
\text { recibida por un Estado } \\
\text { Contratante en virtud del } \\
\text { párrafo } 1 \text { será mantenida } \\
\text { en secreto de la misma } \\
\text { forma que la información } \\
\text { obtenida en virtud del } \\
\text { derecho interno de ese } \\
\text { Estado y sólo se } \\
\text { comunicará a las personas } \\
\text { o autoridades (incluidos } \\
\text { los tribunales y órganos } \\
\text { administrativos) } \\
\text { encargadas de } \\
\text { liquidación o recaudación } \\
\text { de los impuestos a que } \\
\text { hace referencia el párrafo } \\
\text { 1, de su aplicación } \\
\text { efectiva, de la persecución } \\
\text { de su incumplimiento o de } \\
\text { la resolución de los } \\
\text { recursos en relación a los } \\
\text { mismos, o de supervisión } \\
\text { de las funciones }\end{array}$ \\
\hline
\end{tabular}




\begin{tabular}{|c|c|c|c|c|c|c|}
\hline $\begin{array}{l}\text { recursos relativos a los } \\
\text { mismos. Dichas } \\
\text { personas o autoridades } \\
\text { sólo utilizarán estas } \\
\text { informaciones para } \\
\text { estos fines. Podrán } \\
\text { revelar la información } \\
\text { en las audiencias } \\
\text { públicas de los } \\
\text { tribunales o en las } \\
\text { sentencias judiciales. }\end{array}$ & $\begin{array}{lr}\text { mismos. } & \text { Dichas } \\
\text { personas o autoridades } \\
\text { sólo utilizarán estas } \\
\text { informaciones para } \\
\text { estos fines. Podrán } \\
\text { revelar la información } \\
\text { en las audiencias } \\
\text { públicas de los } \\
\text { tribunales o en las } \\
\text { sentencias judiciales. }\end{array}$ & $\begin{array}{l}\text { en este párrafo, de los } \\
\text { procedimientos } \\
\text { declarativos o } \\
\text { ejecutivos relativos a } \\
\text { dichos impuestos, o de } \\
\text { la resolución de los } \\
\text { recursos relativos a los } \\
\text { mismos. Dichas } \\
\text { personas o autoridades } \\
\text { sólo utilizarán estas } \\
\text { informaciones para } \\
\text { estos fines, y de } \\
\text { corresponder, podrán } \\
\text { revelarlas en los } \\
\text { tribunales judiciales, } \\
\text { teniendo presente las } \\
\text { normas constitucionales } \\
\text { y legales de ambos } \\
\text { Estados Contratantes. }\end{array}$ & $\begin{array}{l}\text { del incumplimiento } \\
\text { relativo a los mismos, } \\
\text { de la resolución de los } \\
\text { recursos en relación con } \\
\text { los mismos o de la } \\
\text { supervisión de las } \\
\text { funciones anteriores. } \\
\text { Dichas personas o } \\
\text { autoridades sólo } \\
\text { utilizarán } \\
\text { informaciones para } \\
\text { estos fines. Podrán } \\
\text { desvelar la información } \\
\text { en las audiencias } \\
\text { públicas de los } \\
\text { tribunales o en las } \\
\text { sentencias judiciales. }\end{array}$ & $\begin{array}{l}\text { personas o autoridades } \\
\text { sólo utilizarán la } \\
\text { información para esos } \\
\text { fines. Podrán develar la } \\
\text { información en las } \\
\text { audiencias públicas de } \\
\text { los tribunales o en las } \\
\text { sentencias judiciales. }\end{array}$ & $\begin{array}{l}\text { resolución de los } \\
\text { recursos en relación con } \\
\text { los mismos. Dichas } \\
\text { personas o autoridades } \\
\text { sólo utilizarán la } \\
\text { información para esos } \\
\text { fines. Podrán develar la } \\
\text { información en las } \\
\text { audiencias públicas de } \\
\text { los tribunales o en las } \\
\text { sentencias judiciales. } \\
\text { No obstante lo antes } \\
\text { mencionado, la } \\
\text { información recibida } \\
\text { por un Estado } \\
\text { Contratante puede ser } \\
\text { usada para otros fines } \\
\text { cuando esa información } \\
\text { pueda ser usada para } \\
\text { otros fines de } \\
\text { conformidad con las } \\
\text { leyes de ambos Estados } \\
\text { y cuando la autoridad } \\
\text { competente del Estado } \\
\text { que la suministra } \\
\text { autorice dicho uso. }\end{array}$ & $\begin{array}{l}\text { anteriores. } r \text { Dichas } \\
\text { personas o autoridades } \\
\text { sólo utilizarán la } \\
\text { información para esos } \\
\text { fines. Podrán develar la } \\
\text { información en las } \\
\text { audiencias públicas de los } \\
\text { tribunales o en las } \\
\text { sentencias judiciales. }\end{array}$ \\
\hline $\begin{array}{l}\text { 2. En ningún caso las } \\
\text { disposiciones } \\
\text { párrafo del } 1 \text { podrán } \\
\text { interpretarse en el } \\
\text { sentido de obligar a un } \\
\text { Estado Contratante a: }\end{array}$ & $\begin{array}{l}\text { 2. En ningún caso las } \\
\text { disposiciones del } \\
\text { párrafo } 1 \text { podrán } \\
\text { interpretarse en el } \\
\text { sentido de obligar a un } \\
\text { Estado Contratante a: }\end{array}$ & $\begin{array}{l}\text { 2. En ningún caso las } \\
\text { disposiciones del } \\
\text { párrafo } 1 \text { podrán } \\
\text { interpretarse en el } \\
\text { sentido de obligar a un } \\
\text { Estado Contratante a: }\end{array}$ & $\begin{array}{l}\text { 3.En ningún caso las } \\
\text { disposiciones de los } \\
\text { párrafos } 1 \text { y } 2 \text { podrán } \\
\text { interpretarse en el } \\
\text { sentido de obligar a un } \\
\text { Estado Contratante a: }\end{array}$ & $\begin{array}{l}\text { 3. En ningún caso las } \\
\text { disposiciones de los } \\
\text { párrafos } 1 \text { y } 2 \text { se podrán } \\
\text { interpretar en el sentido } \\
\text { de obligar a un } \\
\text { Estado Contratante a: }\end{array}$ & $\begin{array}{l}\text { 3. En ningún caso las } \\
\text { disposiciones de los } \\
\text { párrafos } 1 \text { y } 2 \text { se podrán } \\
\text { interpretar en el sentido } \\
\text { de obligar a un Estado } \\
\text { Contratante a: }\end{array}$ & $\begin{array}{l}\text { 3. En ningún caso las } \\
\text { disposiciones del párrafo } \\
1 \text { y } 2 \text { se podrán interpretar } \\
\text { en el sentido de obligar a } \\
\text { un Estado Contratante a: } \\
\text { a) adoptar medidas } \\
\text { administrativas contrarias }\end{array}$ \\
\hline
\end{tabular}




\begin{tabular}{|c|c|c|c|c|c|c|}
\hline $\begin{array}{l}\text { a) adoptar medidas } \\
\text { administrativas } \\
\text { contrarias a su } \\
\text { legislación o práctica } \\
\text { administrativa, o a las } \\
\text { del otro Estado } \\
\text { Contratante; } \\
\text { b) suministrar } \\
\text { información que no se } \\
\text { pueda obtener sobre la } \\
\text { base de su propia } \\
\text { legislación o en el } \\
\text { ejercicio de su práctica } \\
\text { administrativa normal, } \\
\text { o de las del otro Estado } \\
\text { Contratante; }\end{array}$ & 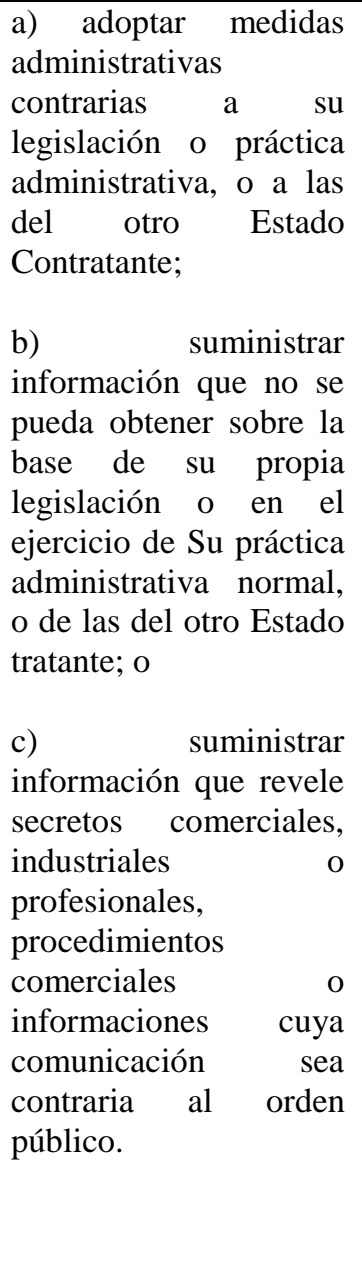 & 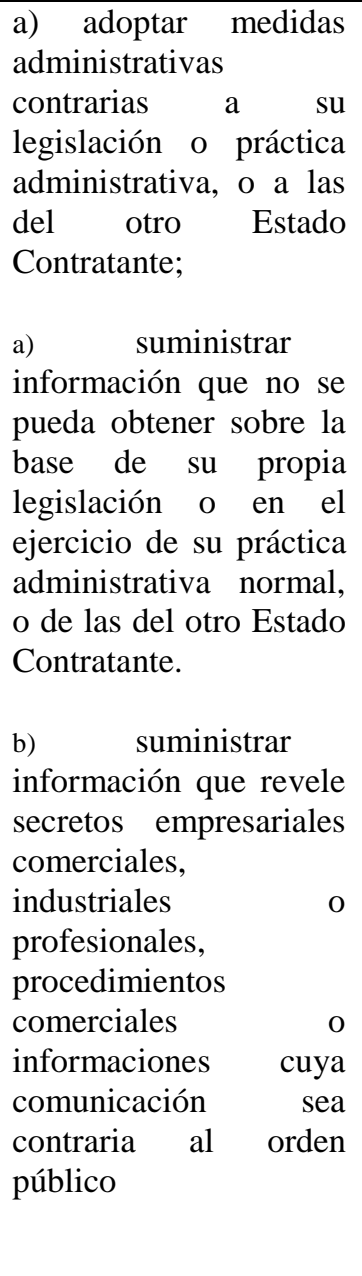 & 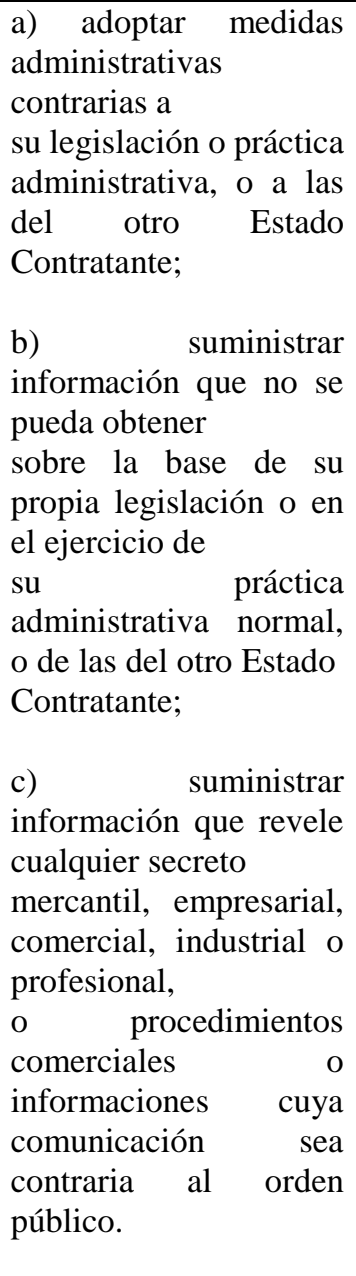 & 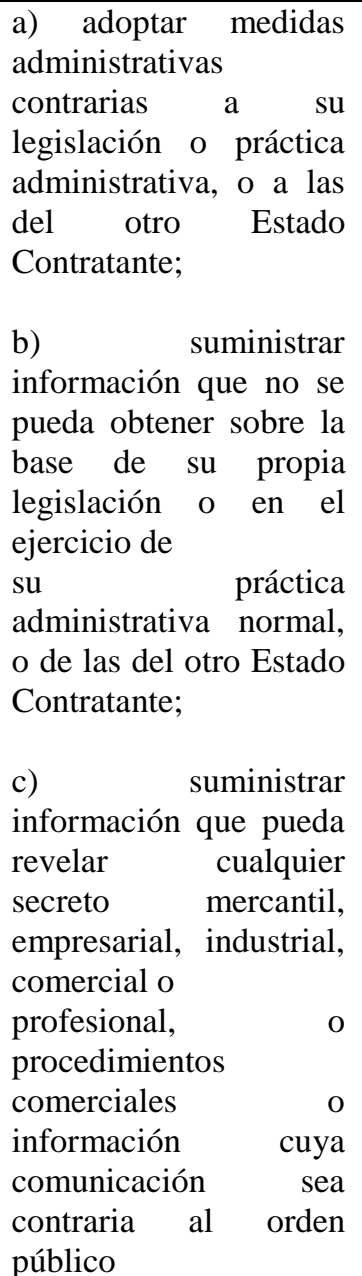 & 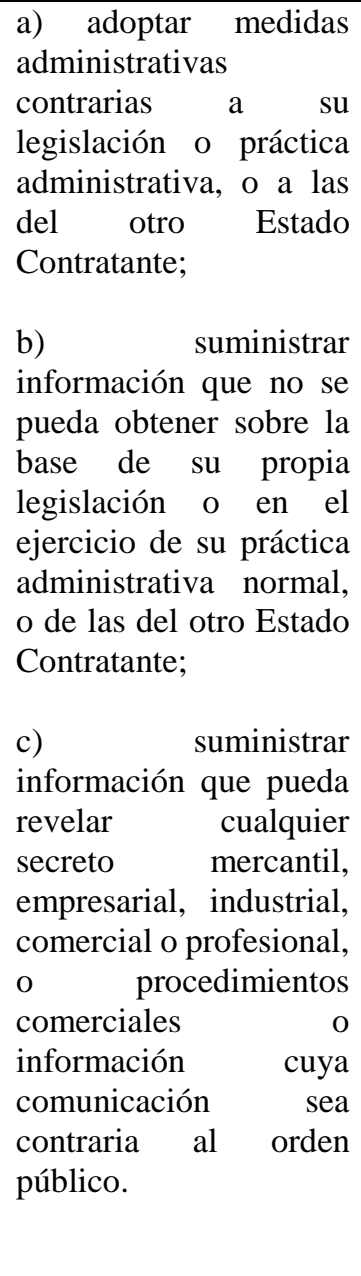 & 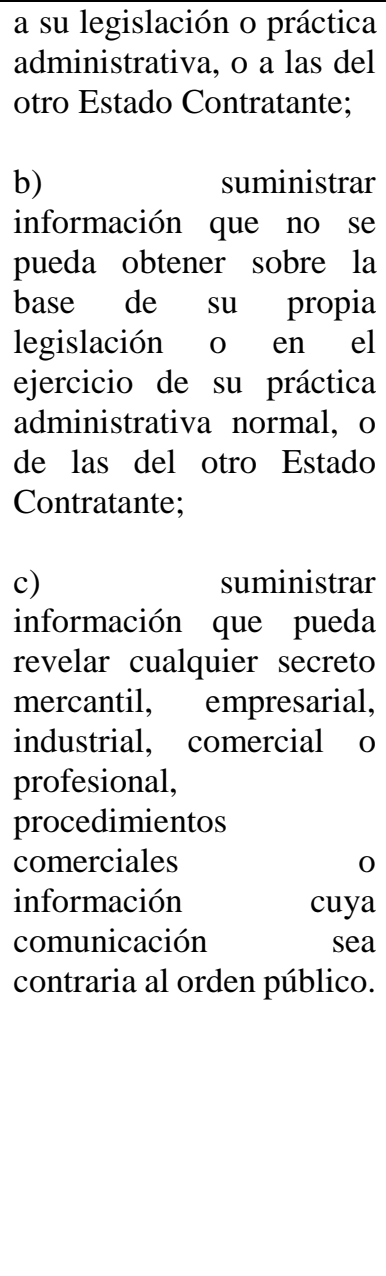 \\
\hline $\begin{array}{lr}. \quad \text { Cuando } & \text { la } \\
\text { información } & \text { sea } \\
\text { solicitada por un Estado } \\
\text { Contratante } & \text { de }\end{array}$ & $\begin{array}{lr}3 . \quad \text { Cuando } & \text { la } \\
\text { información } & \text { sea } \\
\text { solicitada por un Estado } \\
\text { Contratante } & \text { de }\end{array}$ & $\begin{array}{l}\text { 3. No obstante lo } \\
\text { dispuesto en el párrafo } 2 \\
\text { de este artículo, la } \\
\text { autoridad competente }\end{array}$ & $\begin{array}{lr}4 . \quad \text { Cuando } & \text { la } \\
\text { información } & \text { sea } \\
\text { solicitada por un Estado }\end{array}$ & 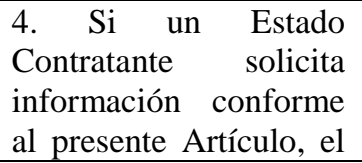 & $\begin{array}{l}\text { 4. Si un } \begin{array}{r}\text { Estado } \\
\text { contratante }\end{array} \\
\text { solicita } \\
\text { información } \\
\text { conforme } \\
\text { al presente Artículo, el }\end{array}$ & 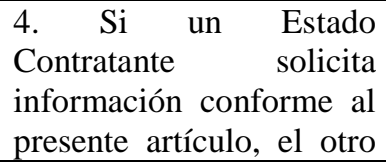 \\
\hline
\end{tabular}




\begin{tabular}{|c|c|c|c|c|c|c|}
\hline $\begin{array}{l}\text { conformidad con el } \\
\text { presente Artículo, el } \\
\text { otro Estado Contratante } \\
\text { obtendrá la información } \\
\text { a que se refiere la } \\
\text { solicitud en la misma } \\
\text { forma como si se tratara } \\
\text { de su propia } \\
\text { imposición, } \\
\text { importar el hecho de } \\
\text { que este otro Estado, en } \\
\text { ese momento, no } \\
\text { requiera de tal } \\
\text { información. }\end{array}$ & $\begin{array}{l}\text { conformidad con el } \\
\text { presente Artículo, el } \\
\text { otro Estado Contratante } \\
\text { hará lo posible por } \\
\text { obtener la información a } \\
\text { que se refiere la } \\
\text { solicitud en la misma } \\
\text { forma como si se tratara } \\
\text { de su propia } \\
\text { imposición, sin } \\
\text { importar el hecho de } \\
\text { que este otro Estado, en } \\
\text { ese momento, no } \\
\text { requiera de tal } \\
\text { información. Si la } \\
\text { autoridad competente } \\
\text { de un Estado } \\
\text { Contratante solicita } \\
\text { información de manera } \\
\text { específica, el otro } \\
\text { Estado Contratante hará } \\
\text { lo posible por obtener la } \\
\text { información a que se } \\
\text { refiere el presente } \\
\text { artículo en la forma } \\
\text { solicitada. }\end{array}$ & 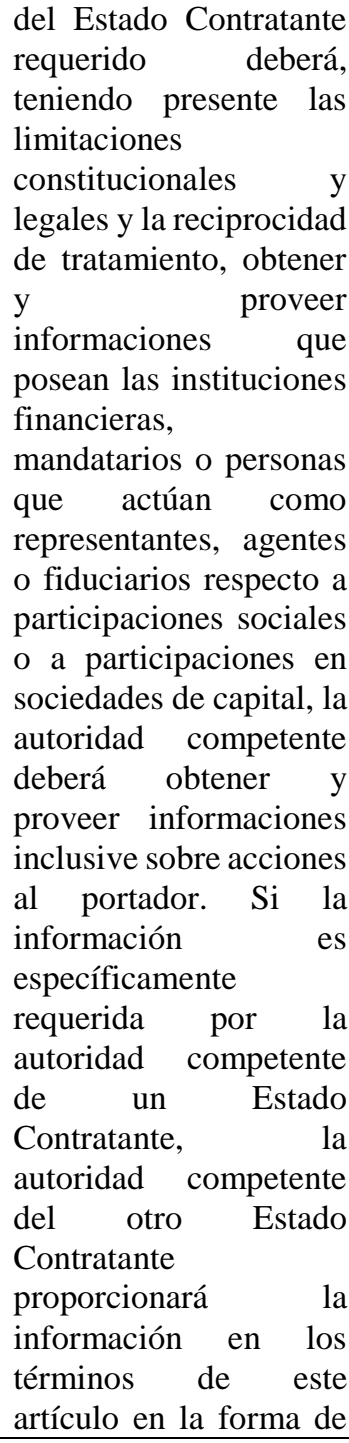 & $\begin{array}{l}\text { Contratante de } \\
\text { conformidad con el } \\
\text { presente Artículo, el } \\
\text { otro Estado Contratante } \\
\text { hará lo posible por } \\
\text { obtener la } \\
\text { información a que se } \\
\text { refiere la solicitud en la } \\
\text { misma forma } \\
\text { como si se tratara de su } \\
\text { propia imposición, sin } \\
\text { importar el hecho de } \\
\text { que este otro Estado, en } \\
\text { ese momento, no } \\
\text { requiera de tal } \\
\text { información. } \\
\text { obligación precedente } \\
\text { está } \\
\text { limitada por lo } \\
\text { dispuesto en el párrafo } 3 \\
\text { siempre y cuando este } \\
\text { párrafo no sea } \\
\text { interpretado para } \\
\text { impedir a un Estado } \\
\text { Contratante } \\
\text { proporcionar } \\
\text { información } \\
\text { exclusivamente por la } \\
\text { ausencia de interés } \\
\text { nacional en la misma }\end{array}$ & 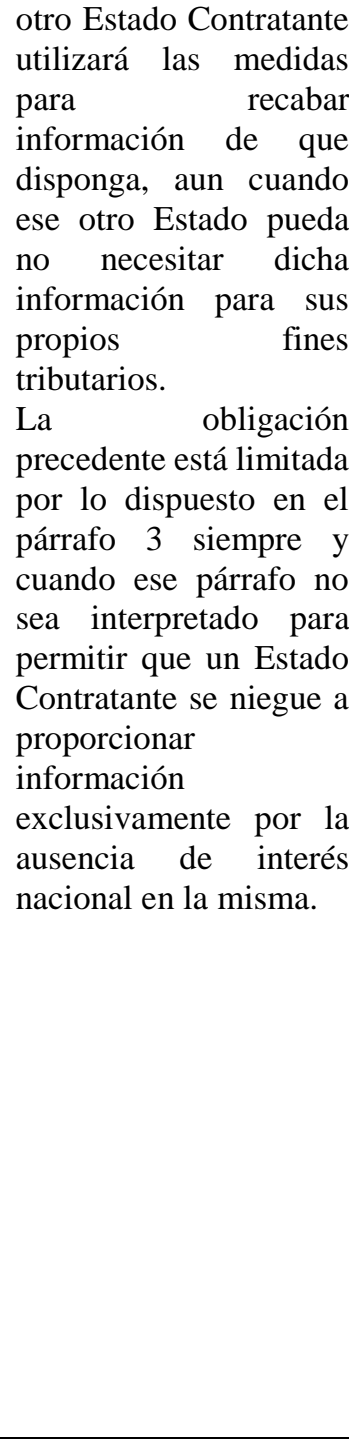 & $\begin{array}{l}\text { otro Estado Contratante } \\
\text { utilizará las medidas } \\
\text { para recabar } \\
\text { información de que } \\
\text { disponga, aun cuando } \\
\text { ese otro Estado pueda } \\
\text { no necesitar dicha } \\
\text { información para sus } \\
\text { propios fines } \\
\text { tributarios. } \\
\text { La obligación } \\
\text { precedente está limitada } \\
\text { por lo dispuesto en el } \\
\text { párrafo } 3 \text { siempre y } \\
\text { cuando ese párrafo no } \\
\text { sea interpretado para } \\
\text { permitir que un Estado } \\
\text { Contratante se niegue a } \\
\text { proporcionar } \\
\text { información } \\
\text { exclusivamente por la } \\
\text { ausencia de interés } \\
\text { nacional en la misma. }\end{array}$ & $\begin{array}{l}\text { Estado Contratante } \\
\text { utilizará las medidas para } \\
\text { recabar información de } \\
\text { que disponga, con el fi n } \\
\text { de obtener la información } \\
\text { solicitada, aún cuando ese } \\
\text { otro Estado pueda no } \\
\text { necesitar dicha } \\
\text { información para sus } \\
\text { propios fines tributarios. } \\
\text { La obligación precedente } \\
\text { está limitada por lo } \\
\text { dispuesto en el párrafo } 3 \text {, } \\
\text { siempre y cuando ese } \\
\text { párrafo no sea } \\
\text { interpretado para permitir } \\
\text { que un Estado Contratante } \\
\text { se niegue a proporcionar } \\
\text { información por la } \\
\text { exclusivamente por la misma. } \\
\text { ausencia de interés } \\
\text { nacional en la misma }\end{array}$ \\
\hline
\end{tabular}




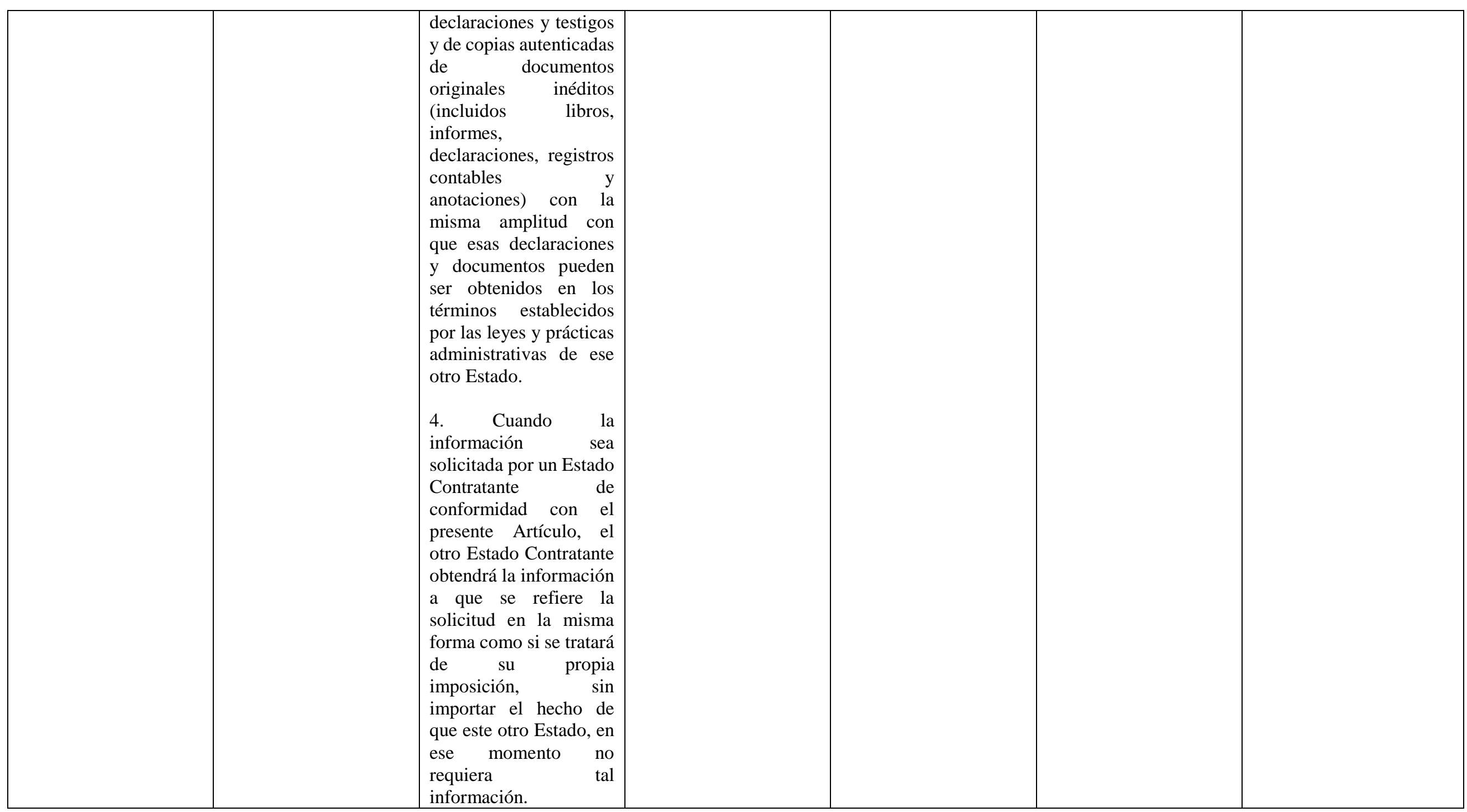




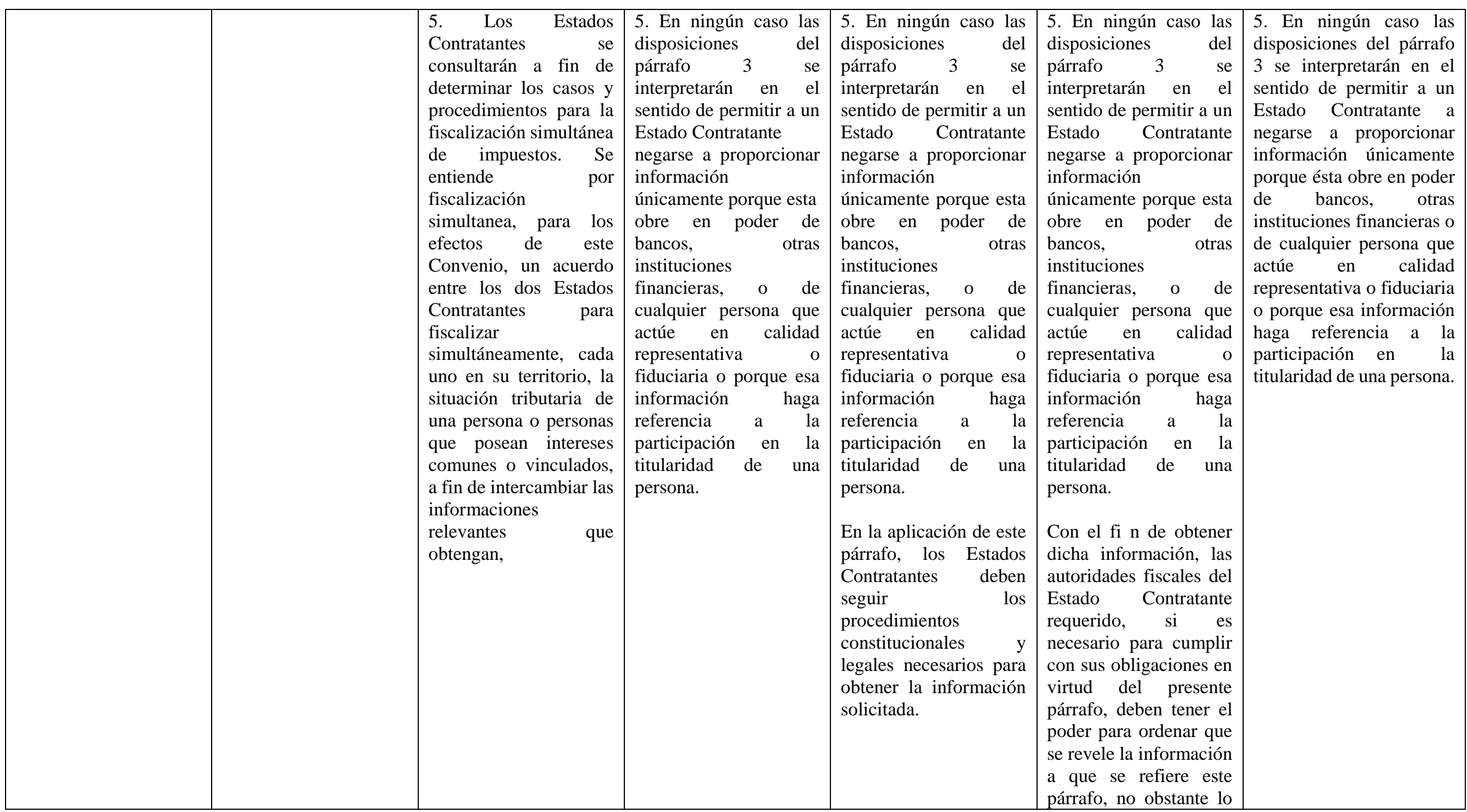




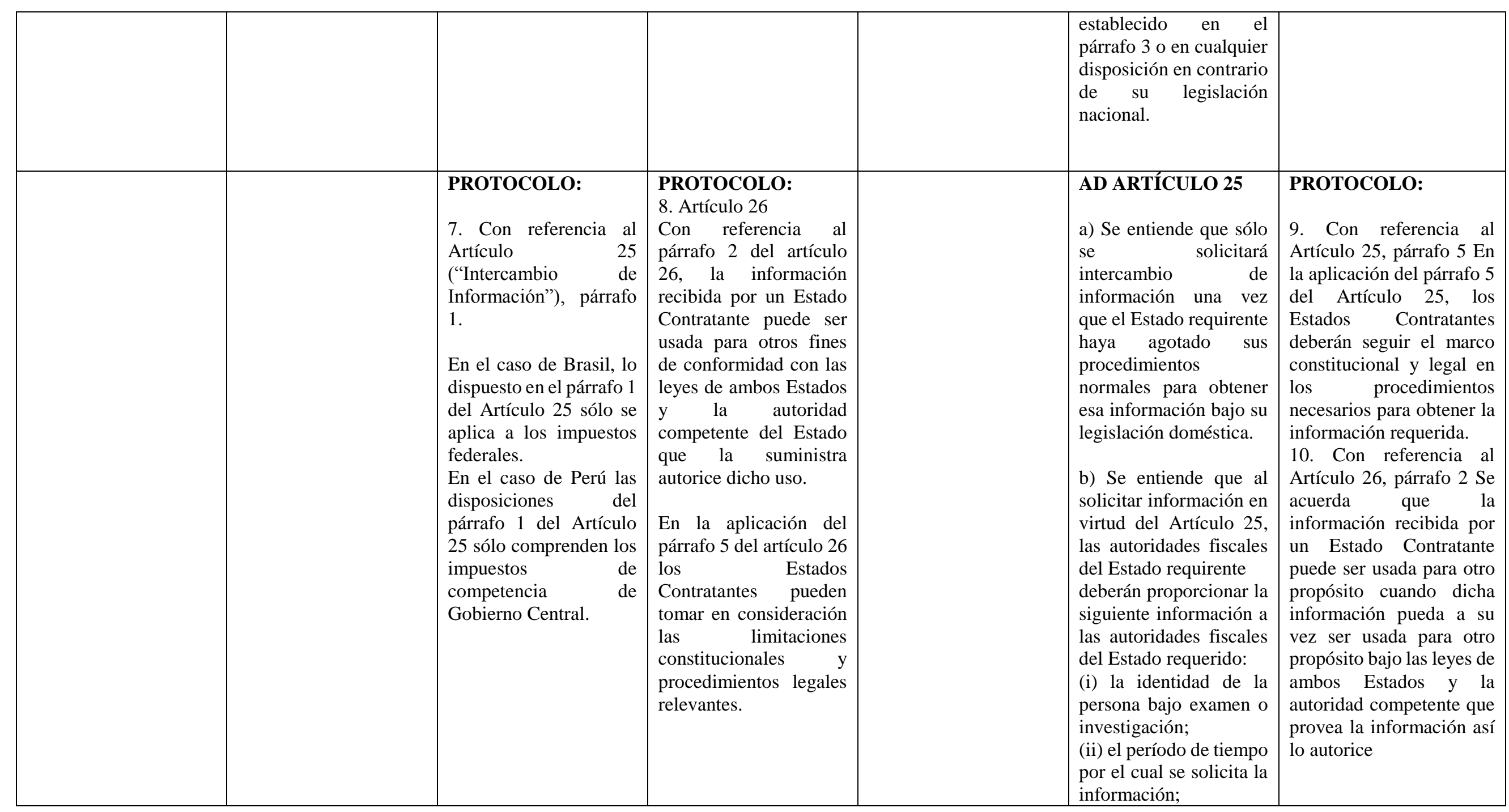




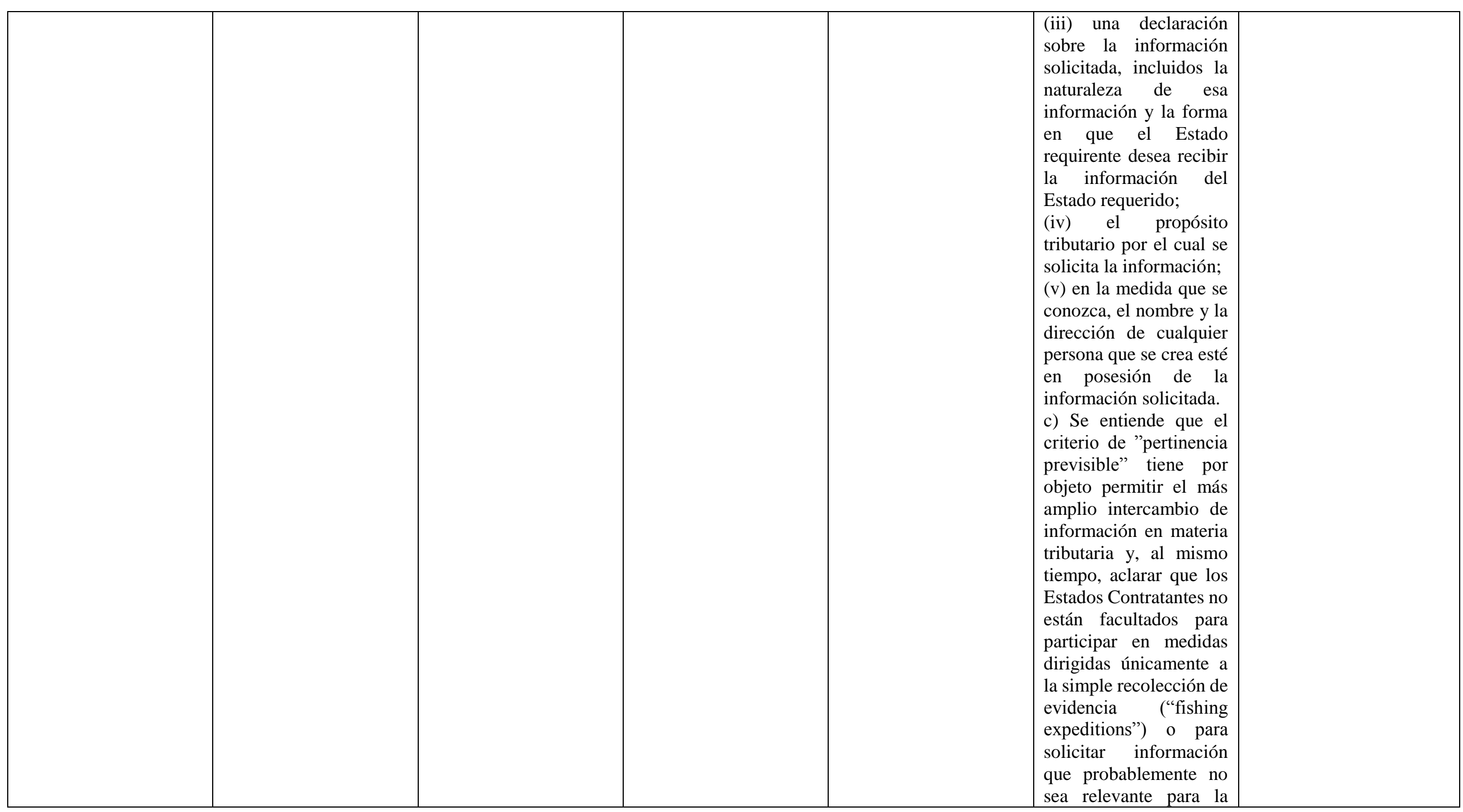




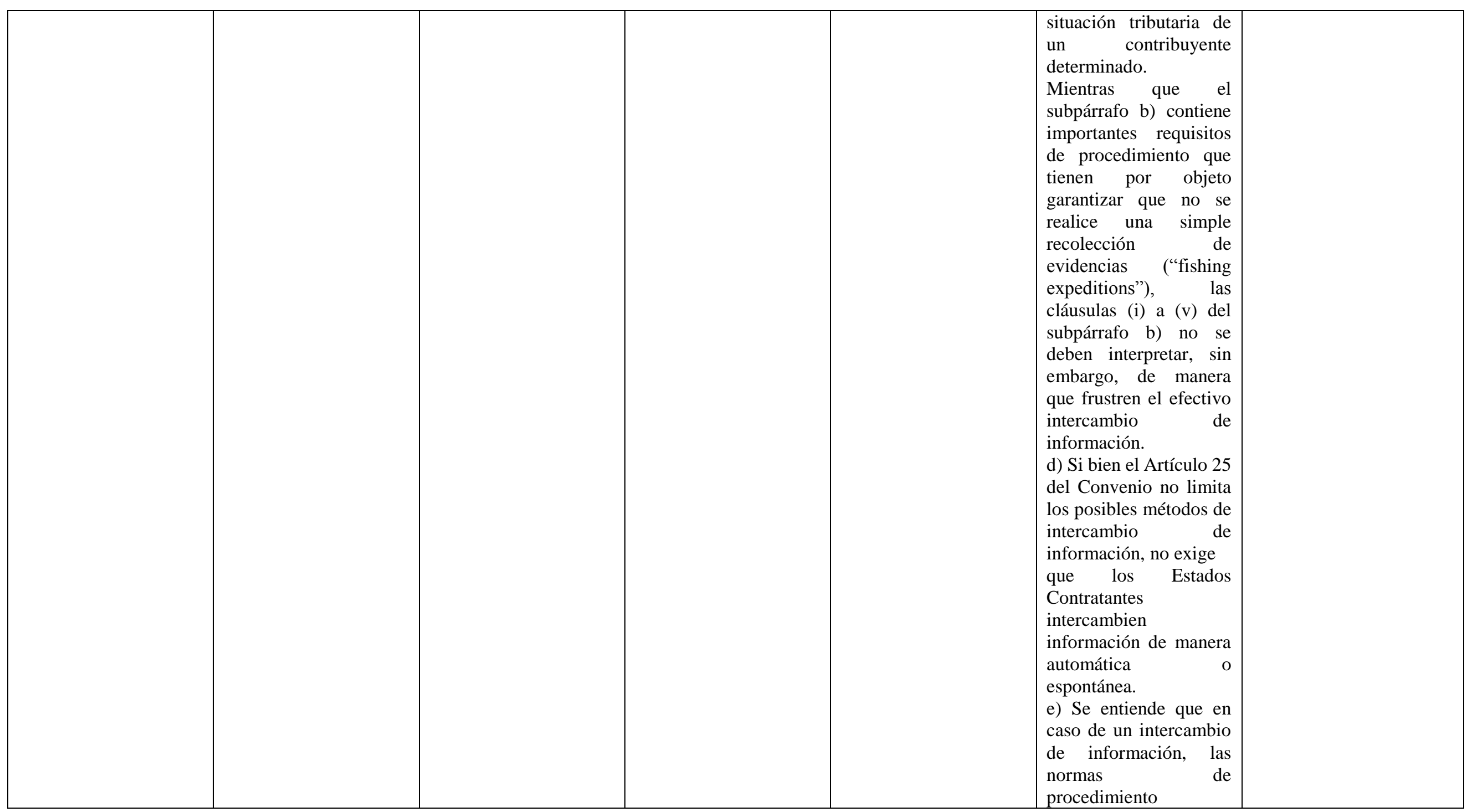




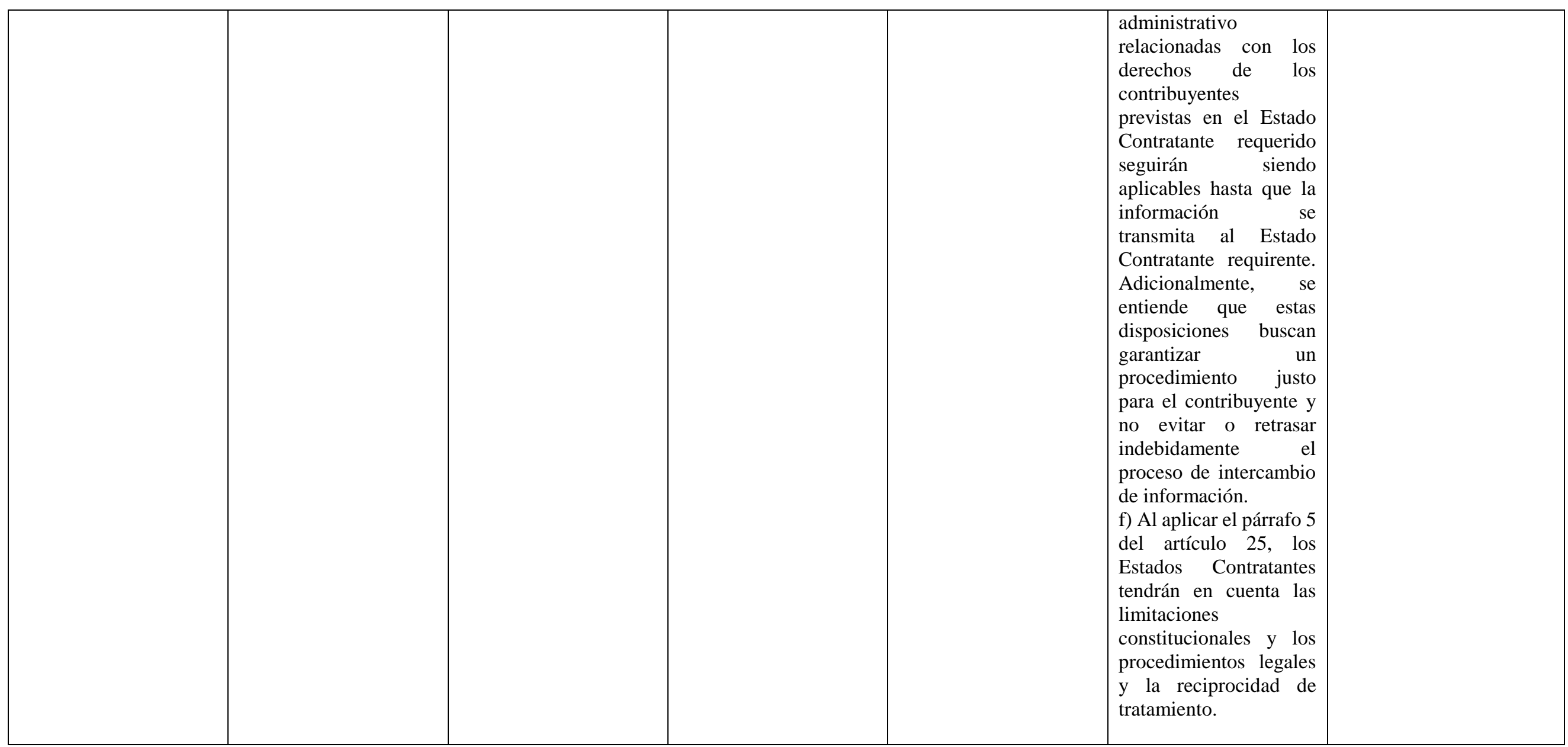

